\title{
Benchmark assessment of orphaned and vulnerable children in areas of the Zambia Family (ZAMFAM) Project
}

\author{
Michael Mbizvo \\ Population Council \\ Paul C. Hewett \\ Population Council \\ Nkomba Kayeyi \\ Population Council \\ Lyson Phiri \\ Population Council \\ Saziso N. Mulenga \\ Population Council
}

See next page for additional authors

Follow this and additional works at: https://knowledgecommons.popcouncil.org/departments_sbsr-hiv

Part of the Demography, Population, and Ecology Commons, Family, Life Course, and Society Commons, International Public Health Commons, and the Maternal and Child Health Commons How does access to this work benefit you? Let us know!

\section{Recommended Citation}

Mbizvo, Michael, Paul C. Hewett, Nkomba Kayeyi, Lyson Phiri, Saziso N. Mulenga, Bwalya Mushiki, and Mwelwa Chibuye. 2018. "Benchmark assessment of orphaned and vulnerable children in areas of the Zambia Family (ZAMFAM) Project." Lusaka: Population Council. 


\section{Authors}

Michael Mbizvo, Paul C. Hewett, Nkomba Kayeyi, Lyson Phiri, Saziso N. Mulenga, Bwalya Mushiki, and Mwelwa Chibuye 


\section{Benchmark Assessment of Orphaned and Vulnerable Children in Areas of the Zambia Family (ZAMFAM) Project}

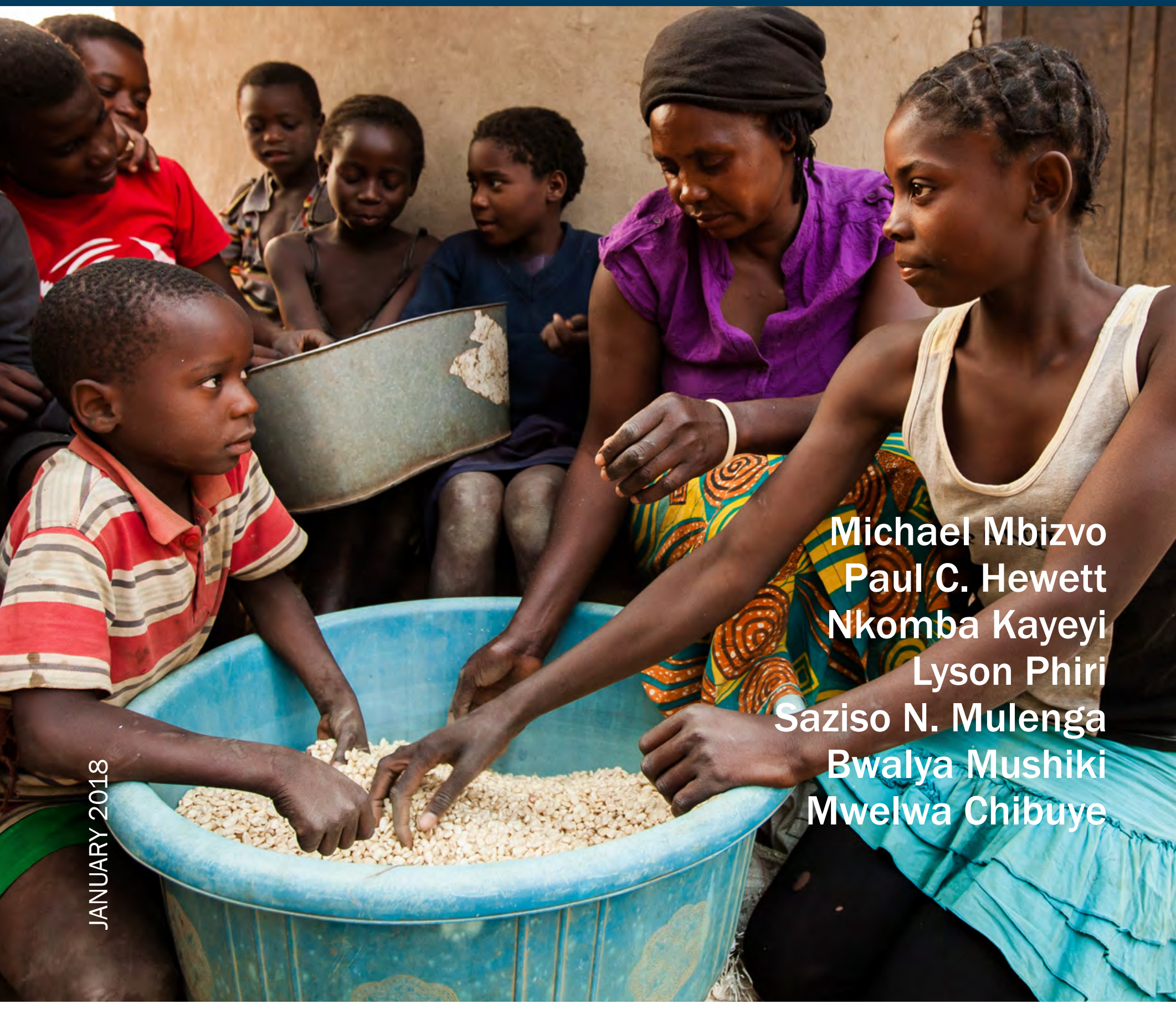




\section{Benchmark assessment of orphaned and vulnerable children in areas of the Zambia Family (ZAMFAM) Project}

Population Council

Michael Mbizvo

Paul C. Hewett

Nkomba Kayeyi

Lyson Phiri

Saziso N. Mulenga

Bwalya Mushiki

Mwelwa Chibuye

Jean Digitale 
Project SOAR

Population Council

4301 Connecticut Ave, NW, Suite 280

Washington, D.C. 20008 USA

Tel: +1202 2379400

Fax: +1 2022378410

projsoar.org

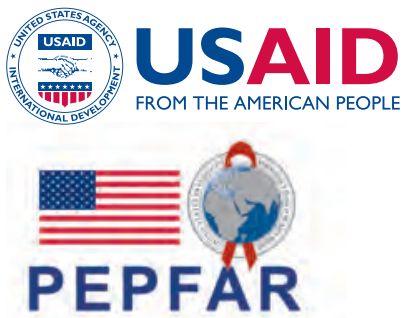

Project SOAR (Cooperative Agreement AID-OAA-A-14-00060) is made possible by the generous support of the American people through the President's Emergency Plan for AIDS Relief and the United States Agency for International Development (USAID). The contents of this report are the sole responsibility of Project SOAR and the Population Council and do not necessarily reflect the views of USAID or the United States Government.

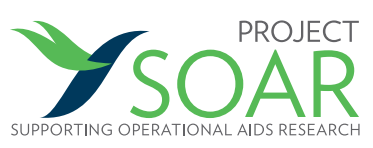

Through operations research, Project SOAR will determine how best to address challenges and gaps that remain in the delivery of HIV and AIDS care and support, treatment, and prevention services. Project SOAR will produce a large, multifaceted body of high-quality evidence to guide the planning and implementation of HIV and AIDS programs and policies. Led by the Population Council, Project SOAR is implemented in collaboration with Avenir Health, Elizabeth Glaser Pediatric AIDS Foundation, Johns Hopkins University, Palladium, and The University of North Carolina.

The Population Council confronts critical health and development issues-from stopping the spread of HIV to improving reproductive health and ensuring that young people lead full and productive lives. Through biomedical, social science and public health research in about 50 countries, the Council works with our partners to deliver solutions that lead to more effective policies, programs, and technologies to improve lives worldwide. Established in 1952 and headquartered in New York, the Council is a nongovernmental, nonprofit organization with an international board of trustees.

Published in January 2018.

(C)2018 The Population Council, Inc.

Suggested citation: Mbizvo, Michael, Paul C. Hewett, Nkomba Kayeyi, Lyson Phiri, Saziso N. Mulenga, Bwalya Mushiki, Mwelwa Chibuye, and Jean Digitale. 2018. "Benchmark assessment of orphaned and vulnerable children in areas of the Zambia Family (ZAMFAM) Project," Project SOAR Final Report. Washington, D.C.: Population Council. 


\section{TABLE OF CONTENTS}

ACKNOWLEDGMENTS................................................................................................

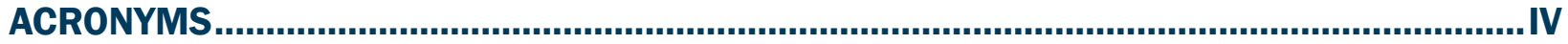

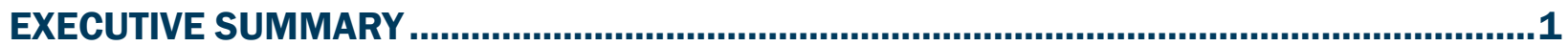

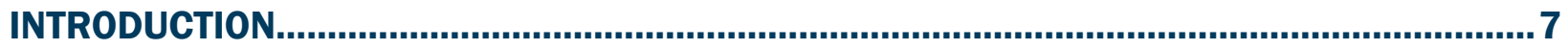

BACKGROUND

METHODOLOGY

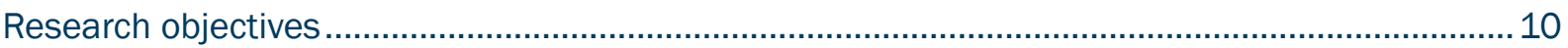

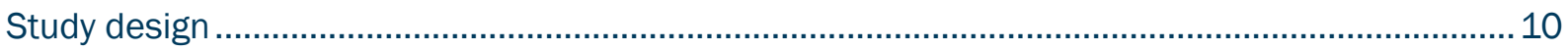

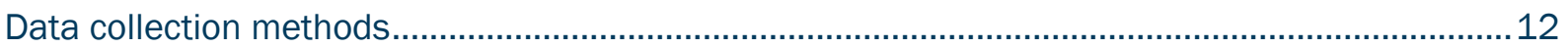

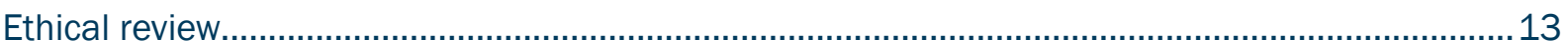

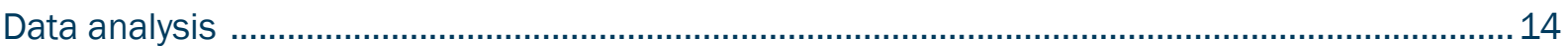

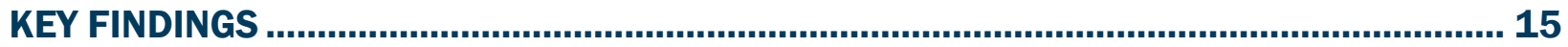

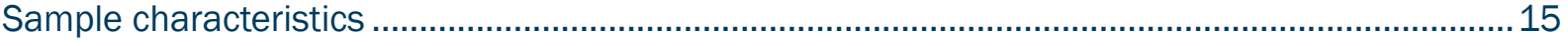

PEPFAR essential indicators for OVC programs …………………………………………….... 21

Additional PEPFAR CORE indicators for OVC programs ………....................................................2

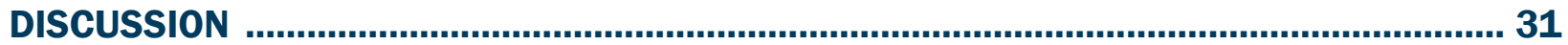

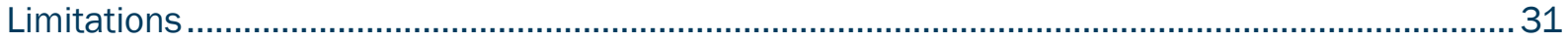

CONCLUSIONS AND RECOMMENDATIONS BY INVESTIGATORS......................................... 33

FOLLOW-UP ACTIONS PROPOSED BY IMPLEMENTING PARTNERS

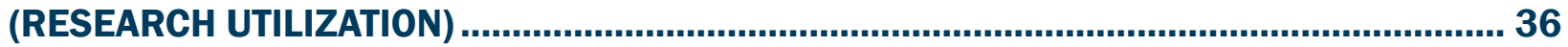

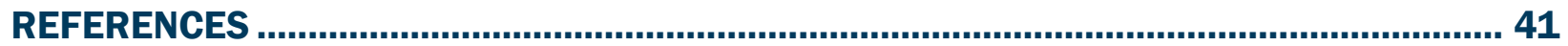

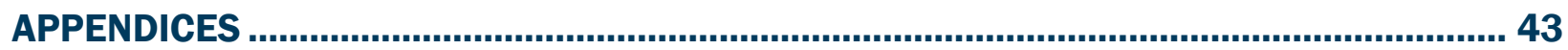

Appendix 1 Zambian Government definition of a vulnerable child.......................................................44

Appendix 2 List of PEPFAR priority districts in four provinces of study and essential

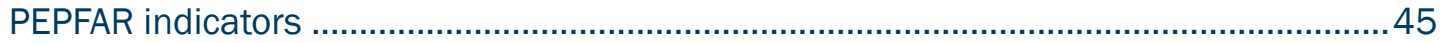

Appendix 3 PEPFAR MER essential indicators for OVC programs .....................................................46 
Appendix 4 PEFPAR MER core indicators for OVC Programs .50

Appendix 5 Confidentiality agreement for data collectors ...............................................................5

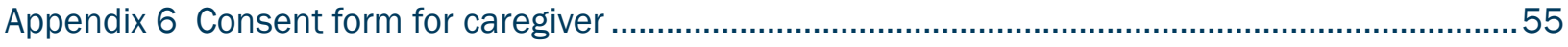

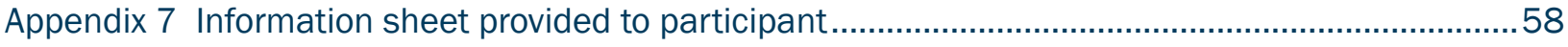

Appendix 8 Information and parent/guardian permission form for child participation .....................59

Appendix 9 Information sheet provided to participant..................................................................62

Appendix 10 Child assent $(10-17$ year olds) .................................................................................63

Appendix 11 Information sheet provided to participant...................................................................66

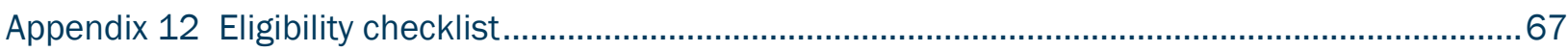

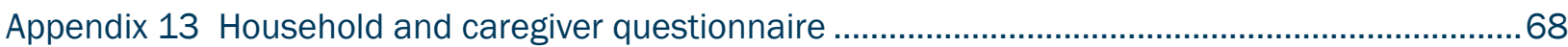

Appendix 14 Intervention summary reports by ZAMFAM partners.................................................110 


\section{ACKNOWLEDGMENTS}

The ZAMFAM benchmark survey was conducted by Project SOAR at the Population Council. We would like to thank the implementing partners of ZAMFAM, Expanded Churches Response Trust (ECR) in Copperbelt and Lusaka Provinces, and Development Aid from People to People (DAPP) in Central and Southern Provinces for their support and cooperation during the data collection process.

In addition, we wish to acknowledge the community-based organizations (CBOs), community health volunteers, village communities, and the Community Welfare Assistance Committees (CWACs) for their effort in ensuring that we located the selected households for the benchmark. Without their help, it would have been impossible to locate the selected participants.

We are also immensely grateful to the technical advisory group and its chair-Dr. Davy Chikamata, then Permanent Secretary for the Ministry of Community Development and Social Services-for finding time to provide guidance for the benchmark survey. We are further grateful to the Government of the Republic of Zambia, through the Ministry of Health and the Ministry of Community Development and Social Services, for approving the study and for availing the services of their staff in the various provinces and districts where the benchmark survey was conducted.

We wish to thank the participants of the ZAMFAM benchmark survey. We acknowledge the warm welcome they showed to the enumerators during the data collection and their willingness to provide information about themselves.

We would also like to show our gratitude to the fieldwork enumerators and supervisors who worked very hard, sometimes in difficult conditions, to ensure that all selected households were located and study participants interviewed. Further acknowledgement to the Population Council support staff for ensuring that the logistics for the evaluation were in place and field work was conducted smoothly.

Finally, we would like to thank USAID and PEPFAR for funding the ZAMFAM project and the benchmark evaluation. We further wish to thank the staff from USAID Zambia for their insights, guidance, and expertise that greatly assisted the evaluation. 


\section{ACRONYMS}

$\begin{array}{ll}\text { AIDS } & \text { Acquired immune deficiency syndrome } \\ \text { ART } & \text { Antiretroviral treatment } \\ \text { ARV } & \text { Antiretroviral } \\ \text { CBO } & \text { Community-based organization } \\ \text { CSO } & \text { Central Statistical Office } \\ \text { DAPP } & \text { Development Aid from People to People } \\ \text { DHSS } & \text { Department of Health and Human Services } \\ \text { ECR } & \text { Expanded Church Response } \\ \text { FBO } & \text { Faith-based organization } \\ \text { GRZ } & \text { Government of the Republic of Zambia } \\ \text { HIV } & \text { Human immunodeficiency virus } \\ \text { HTC } & \text { HIV testing and counseling } \\ \text { IP } & \text { Implementing partner } \\ \text { MER } & \text { Monitoring, Evaluation, and Reporting } \\ \text { MOH } & \text { Ministry of Health } \\ \text { MUAC } & \text { Mid-upper arm circumference } \\ \text { NAC } & \text { National AIDS Council } \\ \text { PEPFAR } & \text { U.S. President's Emergency Plan for AIDS Relief } \\ \text { OVC } & \text { Orphans and vulnerable children } \\ \text { WASH } & \text { Water, Sanitation, and Hygiene } \\ \text { WHO } & \text { World Health Organization } \\ \text { ZAMFAM } & \text { Zambia Family project } \\ \text { ZDHS } & \text { Zambia Demographic and Health Survey } \\ \text { ZNNS } & \text { Zambian National Nutrition Survey } \\ & \end{array}$




\section{EXECUTIVE SUMMARY}

The U. S. Agency for International Development (USAID) and U. S. President's Emergency Plan for AIDS Relief (PEPFAR) are supporting the Zambia Family (ZAMFAM) project to strengthen comprehensive, integrated service delivery and support to children living with, affected by, or vulnerable to HIV/AIDS in the Lusaka, Copperbelt, Southern, and Central Provinces of Zambia. ZAMFAM is scaling up activities on orphaned and vulnerable children (OVC) in high-priority sites to provide services to 45,000 households and 225,000 vulnerable children each year. The objective of ZAMFAM is to improve the care and resilience of OVC and their households through child- and family- focused services. To inform that effort, Project SOAR conducted a benchmark survey among beneficiaries in the four provinces of the ZAMFAM program. The benchmark survey measured the status and conditions of OVC and their families. The findings outlined in this report provide a deeper understanding of the needs of OVC families and the gaps in service provision, as well as suggestions for strengthening care and support strategies for OVC in Zambia.

\section{METHODOLOGY}

The benchmark assessment was a cross-sectional survey of 2,034 ZAMFAM beneficiary OVC households in project target communities conducted in the Lusaka and Copperbelt Provinces between May and July of 2016 (about a year after roll-out) and in the Central and Southern Provinces between September and October of 2016 (around the time of program initiation). Interviews were conducted with caregivers about themselves and any OVC in the household between the ages of zero and nine years. OVC in the household between the ages of 10 and 17 years were interviewed directly by the survey team. The study instrument was based on MEASURE Evaluation's “Child, Caregiver \& Household Well-being Survey Tools for Orphans \& Vulnerable Children Programs," and captured PEPFAR Core OVC Indicators, which are listed later in the report. The analysis in this report is descriptive, reviewing the PEPFAR essential and additional core OVC indicators. The study findings were disaggregated by province, age, sex, and residential status where appropriate.

\section{KEY FINDINGS}

The survey results indicate that more than nine out of ten caregivers were women. The mean age of caregivers was 43 years old. The high mean age of caregivers was driven by the substantial proportion of caregivers (32 percent) whose age was greater than 50 years. A significant percent (60 percent) of OVC caregivers were married or cohabitating with their spouse at the time of interview, with the remainder predominantly widowed (26 percent). Caregivers had modest education levels, with 5.9 mean number of years of completed schooling; marginally higher mean number of years completed was observed in urban areas. Slightly more than one in ten OVC caregivers had never attended school. The caregivers had difficulty reading even a simple sentence in their local language, with 33 percent not being able to read at all and 18 percent having difficulty reading. 
Substantial proportions of OVC had not been effectively linked to health, administrative, or educational services. For instance, the HIV status of only about half of OVC (53 percent) was known to the caregiver and a similar percentage of OVC under five years old had not received the required vaccinations against preventable diseases (47 percent). Further, only approximately one in ten OVC were reported to have received a birth certificate (9.5 percent), although these numbers increased to one in four for the very youngest cohort, aged 0-4 years (25 percent). This rate reported for birth certificate registration was higher than that reported for children aged under 5 years in the general population, among whom only 4 percent had a birth certificate, according to the 2013-14 Zambia Demographic and Health Survey (ZDHS). The same ZDHS data reported that 11 percent of children aged 0-4 years were registered with the civil authority. In addition, it also showed that the registration was much higher in urban (20 percent) than rural (7 percent) areas. OVC were also not achieving full engagement with the school system, as late entry (only 42 percent enrolled in school at 6 years of age) and early drop-out (25 percent) were observed among 10-17-year-old (adolescent) OVC. Reasons given for missing school included being sick (26 percent) and having no money to meet schooling requirements (31 percent). Among all the OVC, 37 percent reported being too sick to engage in daily activities such as playing or participating in household chores.

An area of concern is the magnitude of economic and food insecurity faced by OVC households and their families. One out of every two households reported an inability to handle unexpected household expenses (50 percent) in the previous 12 months, while specific indicators covering inability to pay for food (43 percent) and education (34 percent) expenses suggest further economic insecurity. The data suggest that household economic and food insecurity, as reported by adolescent OVC, seem to directly translate into limited OVC school attendance $(p<0.01)$, as well as skipped and missed meals among household members. Urban households were significantly more affected $(p<0.001)$, as they cannot rely on agricultural production or animal husbandry to mitigate their insecurity. The data show that approximately 4 percent of OVC aged 4 and under in the sample were undernourished at the time of the survey. This level of undernutrition among OVC was slightly higher than that reported for the general population of similar age in the 2011 Zambian National Nutrition Survey, which indicated undernutrition rates of less than 1 percent.

The benchmark data indicate that socio-emotional support of OVC caregivers and OVC was a major concern. For instance, more than half of caregivers (53 percent) and 58 percent of adolescent OVC reported a gap in their social support, e.g., having someone to help with chores if they were sick or someone who shows them love and affection. In instances where socioemotional support was available, children were less likely to miss school, $p<0.028$. Although a large proportion ( 87 percent and 83 percent) sought treatment for fever and diarrhea, respectively, there was no significant association with health seeking behavior as measured by seeking advice for diarrhea or fever for those aged 0-5 years. The finding that a substantial proportion of OVC caregivers were older women suggests that social isolation is an issue faced by this population. For OVC adolescents, there was a gap in socio-emotional support as measured by two critical indicators: lack confidants whom they feel they can talk with about personal problems (40 percent) and lack someone in their lives that demonstratively provides them love and affection (23 percent). These findings suggest that adolescents would benefit from improved adult-child communication, especially as a means of disciplining children, given the wide support among caregivers for harsh disciplinary practices. An encouraging finding was that fewer than 1 percent of OVC adolescents reported lacking support across all four social support indicators. 


\section{CONCLUSION AND RECOMMENDATIONS}

The analysis of PEPFAR's essential and core indicators reveals some gaps and opportunities for enhanced programming for OVC families, many of which are already being directly addressed in the design of the USAID-supported ZAMFAM project. A notable gain is the increase in birth certificate registration for the 0 -5-year-olds in the ZAMFAM districts as compared to the rates for the same ages reported by the ZDHS, although levels from both are still low. Below are recommendations for both projects, and for monitoring, evaluation, and research based on the findings of the benchmark study. In addition, we also report on the feedback by implementing partners (IPs) on measures being taken for utilization of findings to inform their OVC interventions.

\section{Program recommendations}

- As indicated, a large percentage of OVC caregivers were older women with little or no formal education. Such women need to maintain their own health, individual capacities, and economic productivity as they age. They were also in need of socio-emotional support. These findings suggest that OVC programs should consider the specific needs of older women who often serve as caregivers to OVC, while also providing additional guidance and support in accessing public services for themselves and those under their charge.

- Zambia's national guidelines stipulate HIV testing and counseling (HTC) of all children and adolescents whose status is unknown. Linking OVC to family- and household-based HTC remains a gap to be addressed by OVC programs and services to fully realize the 90-90-90 goals and improve public health. Mobilization for index-client-referral testing for OVC families or screening for high HIV risk and linking to testing might be considered, with the additional potential of exploring the feasibility of regular HIV self-testing among higher risk OVC, for example, adolescent girls and young women.

- The high prevalence of food insecurity in the households across multiple indicators in the benchmark survey suggest that chronic undernutrition is a considerable problem for OVC households. Sustainable approaches to ensuring continuous access to food for urban households through economic empowerment, as well as improved agricultural production and increased animal husbandry in rural areas, might be considered by OVC programs.

- Linking the OVC household to health care through improved linkages to health facilities or outreach efforts would address significant gaps in the health needs of OVC. The benchmark assessment noted sizable gaps in the health needs of OVC, including low vaccination rates and high rates of sickness, likely due to exposure to infectious disease and unsanitary conditions, and potentially compounded by poor nutrition. The data suggest the need to link OVC to water, sanitation, and hygiene (WASH) programs and outreach. Further, the youngest OVC need to be better linked to maternal and child health clinics during the first year of life, to obtain the requisite vaccinations for preventable diseases. Programs that improve nutrition may also help reduce experiences of acute illness and, therefore, improve OVC well-being.

- Although the data indicate that access to birth certificates among OVC was low, there appears to be considerable progress in this indicator across recent age cohorts. Efforts to improve access to birth certificates would certainly be called for, given the benchmark findings. Monitoring of this indicator for potential continued expansion of access given existing program efforts may be warranted. 
- Irregular school attendance by OVC reveals challenges ahead for maximizing the potential benefits of educating children. While irregular attendance was driven somewhat by sickness or other reasons, the benchmark data suggest that in the Zambian context, it was, rather, late enrollment and early drop-out that were the drivers of irregular school attendance. Addressing the resource constraints of OVC families in meeting educational expenses could potentially reverse some of these adverse outcomes. Enhancing access to pre-primary school education would be productive, given the late official age of school entry.

- Parenting practices are an area for inclusion in future OVC programming, considering the significant impact that parents and guardians have on the social, emotional, and cognitive development of children. While lack of engagement and stimulation of the youngest OVC does not seem to be a prevalent issue in the Zambia context, retrogressive views of the role of harsh physical discipline and lack of socio-emotional support reported by adolescent OVC require focused attention. Programs directed toward improving parental disciplinary practices and norms and parental-child interactions and communications, as well as mentor-based efforts external to the household, could contribute toward more positive outcomes for OVC.

\section{Monitoring, evaluation, and research}

- The benchmark assessment was cross-sectional and, as such, potential positive trends in the indicators in the recent past may be missed. However, subsequent periodic cross-sectional data collection could capture trends on the performance of PEPFAR indicators. A key objective of the PEPFAR OVC programs is to collect and monitor essential survey outcome indicators that "reflect internationally accepted developmental milestones and collectively measure holistic well-being for children and their families," as included in the benchmark study. The benchmark includes findings on the nine PEPFAR essential indicators (seven OVC and two caregivers). These findings point to gaps and needs for targeted and sustained program interventions that cover needs of OVC. As is noted in PEPFAR's monitoring and evaluation guidelines, continual measurement of these indicators over time is necessary (ideally biennially) for fully assessing progress in the indicators and, to some degree, program impact. In addition, more rigorous study designs are needed to attribute changes to specific OVC programs.

- A more refined understanding of the economics of OVC households (production, consumption, income, and assets) would be informative for fully delineating how to address economic insecurity in the household. The economic and labor data on caregivers and OVC themselves contained in the benchmark survey are limiting for exploring the full productive capacity and employment status of household members. A more detailed assessment of household production would be informative to further improvement of OVC programming. Qualitative research focusing on resilience of OVC households and their adaptation to internal and external economic stressors and shocks would be programmatically informative.

- Food insecurity and undernutrition are major concerns among families in Zambia and among OVC. As the benchmark survey findings indicate, cross-sectional evaluations that are limited in scope and duration may miss key periods in the month and/or year in which food insecurity is greatest. This suggests a need for a more detailed and nuanced monitoring and evaluation of OVC household nutritional intake and outcomes. Reported food insecurity was significantly $(p<0.036)$ associated with OVC being too sick to participate in daily activities. Additional research would better improve our understanding of the apparent chronic undernutrition 
reflected by high rates of stunting among children. Research to explore the potential hidden effects of undernutrition on child physical and cognitive development, which impede improvement in health and educational outcomes, would be constructive, while cost-benefit assessments of potential nutritional interventions would suggest promising directions for programs and policies.

- The benchmark findings suggest that adolescent OVC need improved socio-emotional support from their families and communities or other appropriate sources. Best practices for sensitizing and educating caregivers about the emotional needs of adolescents and methods for enhancing familial relationships and connections is limited in the Zambian context. Understanding how these connections influence mental health among OVC households, and how these impact educational and health outcomes and economic productivity, is nascent at best.

- Given the importance of early and late adolescence in recent HIV prevention efforts, and the need for a healthy transition to adulthood, particularly among girls, understanding the interplay between socio-emotional connectedness and risk behaviors for HIV-negative children and care and treatment behaviors for HIV-positive children would represent an important step toward adequately responding to the global notion of "leaving no one behind," and Zambia's effort to attain the 90-90-90 goals. Interventions that are underpinned by evidence should play a significant role in guiding the Zambia response.

\section{Summary of follow-up actions (research utilization) to inform intervention programs}

Summary of follow-up actions to inform intervention programs that were proposed by implementing partners (IPs) include:

- Using disaggregated data-presented in the report tables-to identify most at-risk OVC populations for enhanced and appropriately tailored program interventions

- Further training of community volunteers to enhance assessment of social, psychological, and emotional needs of caregivers, with a view to strengthening their capacity to provide a comprehensive range of services to caregivers

- Training by ZAMFAM IPs for lay counselors to conduct index-client-referral HIV testing to reach children and adolescents with unknown HIV status to increase knowledge on their status and contribute to 90-90-90 goals.

- Making efforts to help OVC know where to access and how to use antiretroviral treatment (ART) services, especially within integrated care services.

- Strengthening linkages and referral networks between ART providers and communities to support the continuum of care.

- Screening of the nutritional status of children ages 0 to 15 years and providing nutritional services through community- and faith-based organizations and volunteers.

- Strengthening existing community savings groups and creating new ones, continuing to provide mentorships until the groups are self-sustaining.

- Further training community volunteers to facilitate birth registration for OVC, and IPs following up to improve issuance of birth certificates. 
- Chiefs, headmen, and relevant local authorities working with appropriate government ministries engaging in efforts to develop and strengthen community development plans towards sustainably responding to OVC needs. 


\section{INTRODUCTION}

USAID is supporting the Zambia Family (ZAMFAM), a five-year project (2015-2020) to strengthen comprehensive, integrated, service delivery and support to children living with, affected by, or vulnerable to HIV/AIDS. The goal of the project is to improve the care and resilience of orphans and vulnerable children (OVC) and their households in four target provinces: Lusaka, Copperbelt, Central, and Southern. ZAMFAM is providing child- and family-focused services, including community-based child welfare support and sustainable delivery of a full array of services needed for families. Expanded Church Response (ECR) Trust is implementing ZAMFAM in Lusaka and Copperbelt Provinces, while Development Aid from People to People (DAPP) is implementing the program in Southern and Central Provinces. ZAMFAM is scaling up activities for OVC in high-priority sites to maintain service provision to 45,000 households and 225,000 vulnerable children each year.

Project SOAR conducted a benchmark assessment in 2016 of caregivers and children living with, affected by, or vulnerable to HIV/AIDS in the four ZAMFAM target provinces. The benchmark assessment was conducted among OVC households that are beneficiaries of, and registered with, ZAMFAM. The objective of the benchmark assessment was to document the core U.S. President's Emergency Plan for AIDS Relief (PEPFAR) indicators related to child and household well-being among OVC. PEPFAR has established OVC-related outcome indicators for the purposes of monitoring and tracking critical outcomes among recipients of PEFPAR-supported OVC programs (Measure Evaluation 2014b). The benchmark assessment obtained information about the key areas of household well-being targeted by ZAMFAM, including general health and nutrition, food security, shelter, schooling, child protection, psychosocial status, and HIV testing,

The benchmark, which serves as a baseline assessment, was designed to inform the Zambia care and support strategy for OVC, improve PEPFAR Zambia programming, and inform the national Zambia and global PEPFAR policy agendas for HIV care and support. The assessment also provides a deeper understanding of the needs of OVC families and direct programming to strengthen care and support strategies in Zambia. 


\section{BACKGROUND}

Zambia's HIV prevalence, estimated at 13 percent nationally (Central Statistical Office (CSO), Ministry of Health [Zambia] (MOH), and ICF International 2014) presents a formidable challenge for families, communities, and the country overall. According to the Zambian National HIV/AIDS/ STI/TB Council, up to 10 percent of Zambia's population (over 1,300,000 children under age 18 years) is orphaned or vulnerable to HIV (National HIV/AIDS/STI/TB Council 2012). Among these children, approximately 600,000 have been orphaned due to HIV/AIDS. The highest numbers of OVC were in the Southern Province (181,673), followed by Lusaka Province (150,626 orphaned children, including 32,000 double orphans), Copperbelt Province (148,720 orphaned children, including 34,000 double orphans), and Central Province $(128,233)$ (Central Statistical Office 2012, Biemba et al. 2009). Approximately 12 percent and 7 percent of OVC in Lusaka and Copperbelt Provinces, respectively, have a very sick parent or live in a household where an adult has been very sick or died in the past 12 months (CSO et al. 2009).

The impact of HIV is multi-dimensional and has far-reaching consequences, especially for children from families that are affected by the epidemic. The prolonged illness or death of a household member or addition of an orphaned child can disrupt household stability and increase vulnerability. The adverse consequences among children include limited access to education and economic opportunities, and vulnerability to poor health outcomes, including early death, abuse, and poor nutrition. In sub-Saharan Africa, OVC are more vulnerable than non-OVC to negative life experiences (Andrews, Skinner, and Zuma 2006). Studies have shown that well-designed, community-based OVC care and/or support programs can have a positive impact on OVC outcomes (Chatterji et al. 2010).

\author{
Definition of a vulnerable child: \\ ZAMFAM adheres to the Zambian \\ government's definition of a vulnerable \\ child to determine program eligibility: \\ a child below the age of 18 who is \\ living in adverse conditions, e.g., HIV- \\ positive, chronically ill, orphaned, \\ disabled; where $\mathrm{s} /$ he is likely to \\ suffer significant physical, emotional, \\ or mental stress that may result in \\ the child's rights not being fulfilled \\ and, therefore, not enjoying their full \\ development. Appendix 1 provides a \\ complete list of adverse conditions.
}

To address the challenges of OVC families, ZAMFAM is using a community-based approach and works primarily through government structures that oversee activities for vulnerable populations, as well as through faith-based organizations (FBOs), schools, community-based organizations (CBOs), and private structures, especially those also funded by USAID. Briefly, para social workers and community volunteer caregivers are using a household-centered approach, visiting families to develop family-tailored care plans and to motivate their uptake of community-level services. Community-level activities are supporting households and children affected by or living with HIV with needs-based, age-appropriate interventions that address four root problems that impact families' ability to meet the needs of OVC: Iow self-efficacy, poverty, poor psychosocial wellbeing of the caregiver, and low parenting knowledge and skills. Children living with HIV or most vulnerable to HIV have been prioritized for ZAMFAM support. Over five years, ZAMFAM is designed to: 
- Strengthen capacities of households to meet basic needs of OVC living with, affected by, or vulnerable to HIV/AIDS (e.g., household economic-strengthening, positive parent involvement).

- Improve the well-being of children living with, affected by, or vulnerable to HIV through provision of and access to quality care and support services (e.g., health and nutrition, schooling, HIV prevention, care and support, psychosocial care and treatment, child social and legal protection activities).

- Strengthen the capacity of government and community structures (by ZAMFAM IPs) to provide care and support to vulnerable children and adolescents living with, affected by, or vulnerable to HIV/AIDS (e.g., capacities of public structures to coordinate OVC services, utilization of linkages and referral networks for HIV related services). 


\section{METHODOLOGY}

\section{RESEARCH OBJECTIVES}

The goal of the benchmark assessment was to document the well-being and status of ZAMFAM beneficiaries, specifically OVC and their caregivers. The specific objectives of the study were to:

1. Describe the general health and nutrition, food security, shelter, schooling, child protection, and social and psychosocial support of OVC households.

2. Determine the extent to which the needs of vulnerable OVC and their households were being met.

3. Assess the capacity of households and their requirements to meet the basic needs of children living with, affected by, or vulnerable to HIV.

\section{STUDY DESIGN}

The benchmark assessment was a cross-sectional survey of 2,034 ZAMFAM beneficiary OVC households in program target communities conducted in the Lusaka and Copperbelt Provinces between May and July of 2016 (about a year after roll-out) and in the Central and Southern provinces between September and October of 2016 (around the time of program initiation). Table 1 below summarizes key components of the study.

Table 1 Summary of components of the benchmark assessment

\begin{tabular}{|c|c|}
\hline \multirow[t]{2}{*}{ Study areas } & Copperbelt, Lusaka provinces: ECR Trust implementation areas \\
\hline & Central, Southern provinces: DAPP implementation areas \\
\hline Study population & $\begin{array}{l}\text { ZAMFAM beneficiaries, specifically: } \\
\text { - Primary caregivers (aged 18+ years old) } \\
\text { - OVC aged 0-9 years (through caregiver interview) } \\
\text { - OVC aged 10-17 years }\end{array}$ \\
\hline Minimum sample size & $\begin{array}{l}1,560 \text { total OVC households in all provinces, } \\
1,560 \text { caregivers \& OVC aged 0-17 years }\end{array}$ \\
\hline Method \& location of survey & $\begin{array}{l}\text { Interviewer-administered survey questionnaire conducted at } \\
\text { caregiver's/OVC's home }\end{array}$ \\
\hline \multirow[t]{3}{*}{ Study instruments } & Caregiver questionnaire \\
\hline & $\begin{array}{l}\text { OVC questionnaires: } \\
\text { - } 0-9 \text { years; administered to caregiver } \\
\text { - 10-17 years; administered directly to the child }\end{array}$ \\
\hline & $\begin{array}{l}\text { Undernourishment measured by obtaining the mid-upper arm } \\
\text { circumference (MUAC) for children 6-59 months }\end{array}$ \\
\hline Timing & e initial months of ZAMFAM implementation start-up in 2 \\
\hline
\end{tabular}




\section{Study areas and participant population}

The benchmark assessment was conducted in the two ZAMFAM implementation areas: (1) the ECR Trust operating provinces (Copperbelt and Lusaka), and (2) DAPP operating provinces (Central and Southern). Participants were recruited from ZAMFAM beneficiary lists provided by ECR and DAPP drawn from PEPFAR priority districts (Appendix 2). The lists were obtained by the IPs from the previous USAID program (STEPS-OVC) and updated as appropriate. The participant population includes primary caregivers who provide care to OVC in their households. Information on the OVC 0-9 years of age was collected through the caregiver. Interviews were conducted directly with OVC 10-17 years of age. If there was both a child 0-9 and a child 10-17 years of age, information was obtained on both OVC. If there was more than one child in either age group, one was randomly selected for the survey. In the survey, no more than one child per age group per household was interviewed-following PEPFAR's OVC survey guidelines. ${ }^{1}$

\section{Sampling design}

Lists of household beneficiaries provided by each IP for each province served as the sampling frame. Sampling of cases was conducted separately for each IP (ECR, DAPP); hence, the study is stratified by pairs of provinces (Lusaka and Copperbelt; Central and Southern). The objective of the sampling was to represent OVC households within the two provinces of each implementing partner, matching as best as possible the varying urban and rural distribution across the two provinces. By example, there was a greater percentage of eligible OVC households in the Copperbelt province (55 percent) than in Lusaka (45 percent), and a greater percentage of eligible OVC households in urban wards ( 74 percent) than rural wards ( 21 percent) in these two provinces. An additional 5 percent of households lived in wards that were mixed urban/rural; in the analysis, these wards were assigned as urban.

Once the number of wards needed for sampling was determined, a two-stage sampling procedure, stratified by urban and rural, was implemented such that wards were selected proportional to size of the OVC beneficiary population, and a fixed number of households per ward were sampled. Sampling proportional to size allows for households in wards with greater numbers of eligible OVC population to have a higher selection probability, while the fixed sampling size per ward allows for the sample to be self-weighting at the analysis stage within each pair of provinces (Groves et al. 2009). Once wards were selected, OVC eligible households enrolled in the ZAMFAM project were randomly ordered and recruited for the benchmark survey. If a household could not be located or refused participation, they were noted as a non-response and replaced by a subsequent household on the randomly ordered list until the target sample was obtained.

The minimum sample size for the baseline assessment was 780 OVC households for each set of two provinces, or 1,560 OVC households for all four provinces. The minimum sample size of caregiver and OVC participants needed for the benchmark survey was determined by setting a minimum acceptable confidence interval of \pm 5 percent for key study indicators for the caregiver and 0 -17 age group; marginally higher confidence intervals of \pm 8 percent and \pm 7 percent were accepted for the 0 to $<5$ and 5 to 17 age groups, respectively. The estimated sample sizes

${ }_{1}^{1}$ PEPFAR, Monitoring, Evaluation, and Reporting [MER 2.0] indicator reference guide, January 2017, https://www.pepfar.gov/ documents/organization/263233.pdf 
accounted for the impact of the clustered sampling approach on the confidence intervals. To achieve the target sample desired for analysis, the minimum sample size was inflated by 25 percent to account for potential non-responses at the household level. In sum, a total of 2,080 households were randomly sampled to be recruited for the benchmark by enumeration teams.

\section{DATA COLLECTION METHODS}

The surveys were conducted in Lusaka and the Copperbelt Provinces between May and July 2016, and in Central and Southern provinces between September and October 2016. The survey team consisted of two study coordinators, four supervisors, and 36 enumerators. Each province had a study coordinator and two supervisors to conduct the survey. Each study supervisor was responsible for about nine enumerators, and they liaised with the community health workers (CHWs) to locate selected households. A total of 36 enumerators conducted the interviews of households that agreed to participate in the study in 2016.

Information was collected at the household level through an electronic survey interview conducted by enumerators on tablet computers using Open Data Kit software. At any given OVC household registered in the ZAMFAM project, the caregiver was asked questions about the household, and about him or herself. If there was an OVC aged 0-9 years in the household, the caregiver was asked questions about this child. If there was more than one OVC aged 0-9, one child of the age group was randomly selected and became the focal point of the interview. If there was an OVC aged 10-17 in the household, they were approached for written assent to be interviewed after consent was obtained from the caregiver. If there was more than one 10-17-year-old OVC in the household, one was randomly selected to be interviewed. As we were following PEPFAR's OVC survey guidelines, no more than one OVC age 0 to 9 or aged 10-17 was eligible for survey participation. If there were more than two children within these age groups in a household, then only one per age group was randomly selected. This process is summarized in Table 2.

Table 2 Survey interviews to be conducted in OVC households

\begin{tabular}{|c|c|c|}
\hline Children in household & \multicolumn{2}{|c|}{ Interviews to be conducted } \\
\hline $\begin{array}{l}\text { Child 0-9 } \\
\text { No child 10-17 }\end{array}$ & $\begin{array}{l}\text { (x1) Caregiver } \\
\text { (x1) Caregiver }\end{array}$ & $\begin{array}{l}\text {-Information about household \& caregiver } \\
\text {-Information about selected child 0-9 }\end{array}$ \\
\hline $\begin{array}{l}\text { No child 0-9 } \\
\text { Child } 10-17\end{array}$ & $\begin{array}{l}\text { (x1) Caregiver } \\
\text { (x1) Child }\end{array}$ & $\begin{array}{l}\text {-Information about household \& caregiver } \\
\text {-Information about selected child 10-17 }\end{array}$ \\
\hline $\begin{array}{l}\text { Child } 0-9 \\
\text { Child } 10-17\end{array}$ & $\begin{array}{l}\text { (x1) Caregiver } \\
\text { (x1) Caregiver } \\
\text { (x1) Child }\end{array}$ & $\begin{array}{l}\text {-Information about household \& caregiver } \\
\text {-Information about select child 0-9 } \\
\text {-Information about select child } 10-17\end{array}$ \\
\hline
\end{tabular}

The rationale for the 0 to 9 and 10 to 17 age groupings are as follows. First, children under the age of 10 are less likely to understand or be knowledgeable about some of the questionnaire content. Second, in our experience, the ethics committees would be reluctant to approve direct administration of the survey to children younger than 10 years of age. Finally, there are concerns that caregiver-provided information on certain topics (e.g., about food intake, educational status, and neglect) may not be accurate, particularly in cases where the caregivers may be inappropriately treating or under-investing in OVC care. Thus, it may be more accurate to obtain 
information, where possible, directly from OVC. The questionnaire was designed and validated to be safely and ethically administered to children 10 years of age and older (Measure Evaluation $2015 a)^{2}$.

\section{Study instruments and indicators}

The benchmark survey collected information on OVC and caregiver well-being as well as household economic status. Per USAID recommendation, the suggested questions in MEASURE Evaluation's Child, Caregiver \& Household Well-being Survey Tools for Orphans \& Vulnerable Children Programs were used as a starting point (Measure Evaluation 2015a).

An objective of PEPFAR OVC programs is to collect and monitor essential outcome indicators that "reflect internationally accepted developmental milestones and collectively measure holistic wellbeing for children and their families" (Measure Evaluation 2015b). The nine PEPFAR essential Monitoring, Evaluation, and Reporting (MER) indicators are noted in Table 3.

\section{Table 3 PEPFAR MER essential indicators}

\begin{tabular}{|c|c|}
\hline No. ${ }^{\dagger}$ & Indicator \\
\hline NC.1 & Percent of children whose primary caregiver knows the child's HIV status \\
\hline CW.1 & Percent of children $<5$ years of age who are undernourished as measured by MUAC \\
\hline CW.4 & Percent of children too sick to participate in daily activities \\
\hline CW.9 & Percent of children who have a birth certificate, observed or self-reported \\
\hline CW.11 & Percent of children aged 5-17 years regularly attending school \\
\hline CW.12 & Percent of children aged 5-17 years who progressed in school during the last year \\
\hline CW.13 & $\begin{array}{l}\text { Percent of children }<5 \text { years of age who recently engaged in stimulating activities with } \\
\text { any household member over } 15 \text { years of age }\end{array}$ \\
\hline CW.14 & $\begin{array}{l}\text { Percent of caregivers who agree that harsh physical punishment is an appropriate } \\
\text { means of discipline or control in the home or school }\end{array}$ \\
\hline HW.2 & Percent of households able to access money to pay for unexpected household expenses \\
\hline
\end{tabular}

†PEPFAR's internal numbering of essential monitoring and evaluation indicators.

\section{ETHICAL REVIEW}

The research protocol was approved by the Population Council Institutional Review Board. The protocol was also reviewed and approved by the local ethical body, ERES Converge. All study investigators and staff were certified in human subjects protection training prior to study initiation. Administrative approvals were also received from the National Health Research Authority, $\mathrm{MOH}$, and Ministry of Community Development and Social Services. All study participants provided written consent if they were age 18 and older; assent and guardian written consent was obtained for all participants under the age of 18.

${ }^{2}$ Consent forms and data collection instruments are available in appendices 5-13. 


\section{DATA ANALYSIS}

As the objective of this report is to describe the well-being and statuses of ZAMFAM beneficiaries, specifically OVC and their caregivers, the primary analysis tools are univariate and bivariate statistics for proportions and means, as appropriate for dichotomous or continuous indicators, respectively. Although the objectives of the study were primarily descriptive, some selected comparisons and associated statistical tests were conducted. Sample sizes, confidence intervals, and $p$-values for selected statistics are provided as measures of the precision and statistical significance of the statistics obtained. The standard errors and the confidence intervals have been adjusted for urban and rural stratification and clustering at the ward level. The two-staged cluster sampling approach yields a self-weighting sample when analyses are completed for the two sets of provinces separately. When an indicator was estimated for all four provinces together, the sample was weighted. The analysis weight adjusts for the distribution of the OVC cases across the provinces and the distribution of cases in urban and rural areas across the provinces. The weighting approximates the results as if the sampling were conducted across the two sampling frames and all four provinces together. The indicators are measured at the household level (caregiver reported) and at the OVC child level. The PEPFAR essential and core indicators are also disaggregated by age, including for 0-4 years, 5-9 years, 10-14 years, and 15-17 years, as recommended in PEPFAR guidelines (Measure Evaluation 2014a). 


\section{KEY FINDINGS}

\section{SAMPLE CHARACTERISTICS}

\section{Distribution of sample}

The study was designed to be separately representative of each of the two sets of provinces in which the IPs, ECR and DAPP, were recruiting and enrolling beneficiaries. As such, two sampling frames were used, consisting of the beneficiary listings provided by each of the IPs. Table 4 shows the distribution of the study sample by IP and residential area. The final benchmark sample matched the original distributions of OVC across provinces in the beneficiary listings (sampling frames) provided by the IPs. For Lusaka and the Copperbelt, the distribution in OVC households in the benchmark sample across the two provinces was 44 percent and 56 percent, respectively. This distribution was only marginally different than the sampling frame of beneficiaries provided by ECR. Similar matching of the distribution across Central and Southern Provinces was obtained, with 80 percent of households in the sample coming from the Central Province and 20 percent from Southern Province.

As indicated in Table 4, the benchmark sample obtained indicates a rural and urban distribution within the Lusaka and Copperbelt Provinces of 20 percent and 80 percent respectively. This distribution changes little when the data are weighted. For the Central and Southern Provinces, the distribution of rural to urban is 55 percent and 45 percent, again with only a slight difference between the weighted and unweighted data. Combined, rural areas represent 36 percent of the sample (weighted data), while urban areas represent 64 percent of the sample (weighted data). What changed most significantly when the analysis weights were applied was the distribution of cases across the two sets of provinces (double bar boxes). Lusaka and Copperbelt represented 48 percent of the cases in the unweighted data and 53 percent of the cases in the weighted data, with Central and Southern Provinces comprising the remainder percent in each case (52 percent and 47 percent, respectively). As previously discussed, when considering statistics for the overall or total sample (across all four provinces), the weighted data are used.

\section{Participation rates}

The minimum sample size for the baseline assessment was $780 \mathrm{OVC}$ households for each set of two provinces, or 1,560 OVC households for all four provinces. Table 5 below provides the total sample obtained and the interview result, by province and residential area (urban and rural). As is noted in the far-right column, a total of 2,034 OVC households were interviewed for the benchmark. The additional cases were obtained above the minimum sample needed as a higher interview rate was observed ( 80 percent of sample cases vs. 75 percent estimated), and because the interview team sampled with replacement. As the beneficiary households were randomly ordered in the sampling frame, the additional cases did not introduce any biases in the estimates.

As is noted in Table 5, the response rate overall was 83 percent of the attempted beneficiary households. The majority of non-response households were due to an inability of the interviewer 


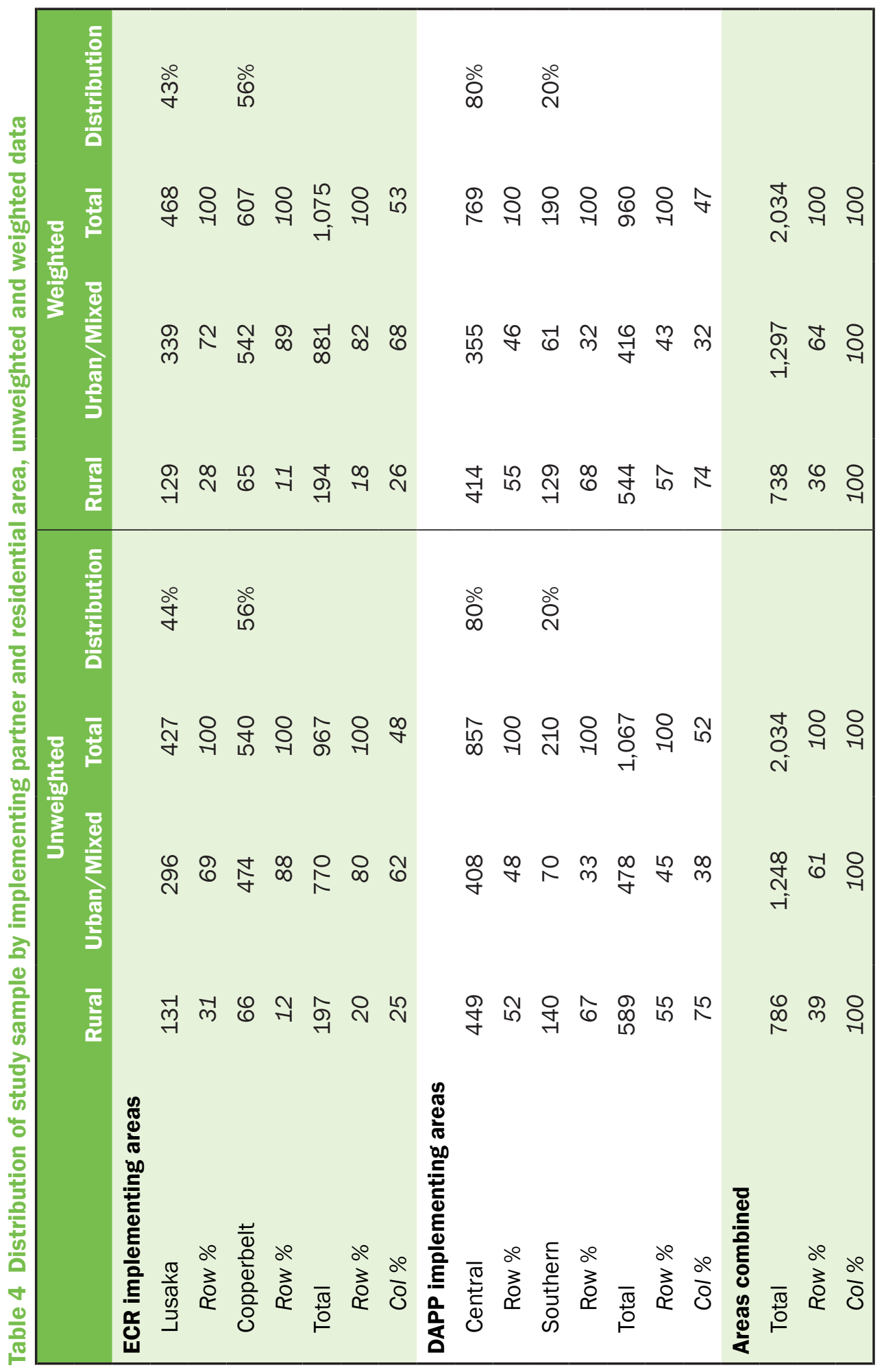


Table 5 Benchmark survey response rates by interview result, provinces, and residence

\begin{tabular}{|c|c|c|c|c|c|c|c|c|c|c|}
\hline & \multicolumn{4}{|c|}{ Lusaka and Copperbelt } & \multicolumn{4}{|c|}{ Central and Southern } & \multicolumn{2}{|c|}{ Total } \\
\hline & \multicolumn{2}{|c|}{ Rural } & \multicolumn{2}{|c|}{ Urban } & \multicolumn{2}{|c|}{ Rural } & \multicolumn{2}{|c|}{ Urban } & \multirow[b]{2}{*}{ No. } & \multirow[b]{2}{*}{$\%$} \\
\hline & No. & $\%$ & No. & $\%$ & No. & $\%$ & No. & $\%$ & & \\
\hline Completed & 197 & 80.4 & 770 & 78.7 & 589 & 86.2 & 478 & 86.1 & 2,034 & 82.6 \\
\hline Refused & 0 & 0.0 & 3 & 0.3 & 1 & 0.1 & 2 & 0.4 & 6 & 0.2 \\
\hline $\begin{array}{l}\text { Failed to } \\
\text { locate } \mathrm{HH}\end{array}$ & 46 & 18.8 & 191 & 19.5 & 54 & 7.9 & 54 & 9.7 & 345 & 14.0 \\
\hline $\begin{array}{l}\mathrm{HH} \text { or OVC } \\
\text { relocated }\end{array}$ & 1 & 0.4 & 9 & 0.9 & 15 & 2.2 & 17 & 3.1 & 42 & 1.7 \\
\hline $\begin{array}{l}\text { Unable } \\
\text { physically or } \\
\text { mentally }\end{array}$ & 0 & 0.0 & 0 & 0.0 & 3 & 0.4 & 0 & 0.0 & 3 & 0.1 \\
\hline Ineligible & 1 & 0.4 & 3 & 0.3 & 5 & 0.7 & 1 & 0.2 & 10 & 0.4 \\
\hline Not available & 0 & 0.0 & 1 & 0.1 & 11 & 1.6 & 2 & 0.4 & 14 & 0.6 \\
\hline Other & 0 & 0.0 & 2 & 0.2 & 5 & 0.7 & 1 & 0.2 & 8 & 0.3 \\
\hline Total & 245 & 100.0 & 979 & 100.0 & 683 & 100.0 & 555 & 100.0 & 2,462 & 100.0 \\
\hline
\end{tabular}

team to locate the beneficiary households with the information provided by the IP. This may be due to the fact that the beneficiary information was inaccurate or, more often, the household relocated, but no confirmation of this fact could be obtained in the field. A much smaller percentage of the non-response cases were due to refusals (<1 percent), known relocations $(2$ percent), or other reasons. There were few differences in urban and rural areas within provinces in the reasons for non-response. However, significant differences were observed across the two sets of provinces: Lusaka and Copperbelt Provinces had twice the percentage of households where the enumeration teams were unable to locate the household.

\section{Caregiver and household characteristics}

Table 6 shows the caregiver and household sociodemographic characteristics from the sample data. In both ECR (Lusaka/Copperbelt) and DAPP (Central/Southern) provinces, the overwhelming percentage of caregivers of OVC children were women, with 91 percent of interviews conducted with women caregivers. In Lusaka and Copperbelt, the percentage of female caregivers is higher than in the other two provinces, but the differences were for the most part minimal. 


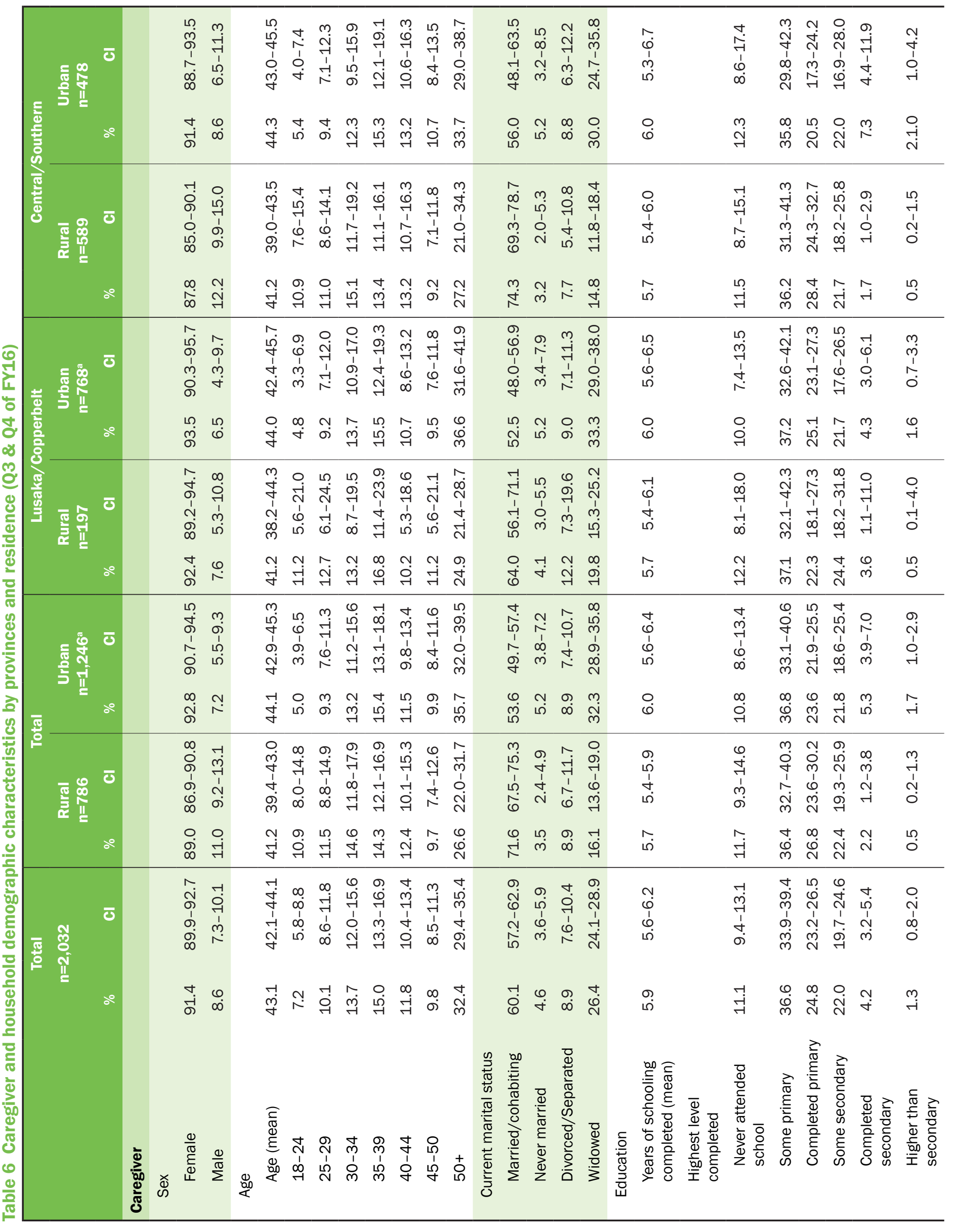




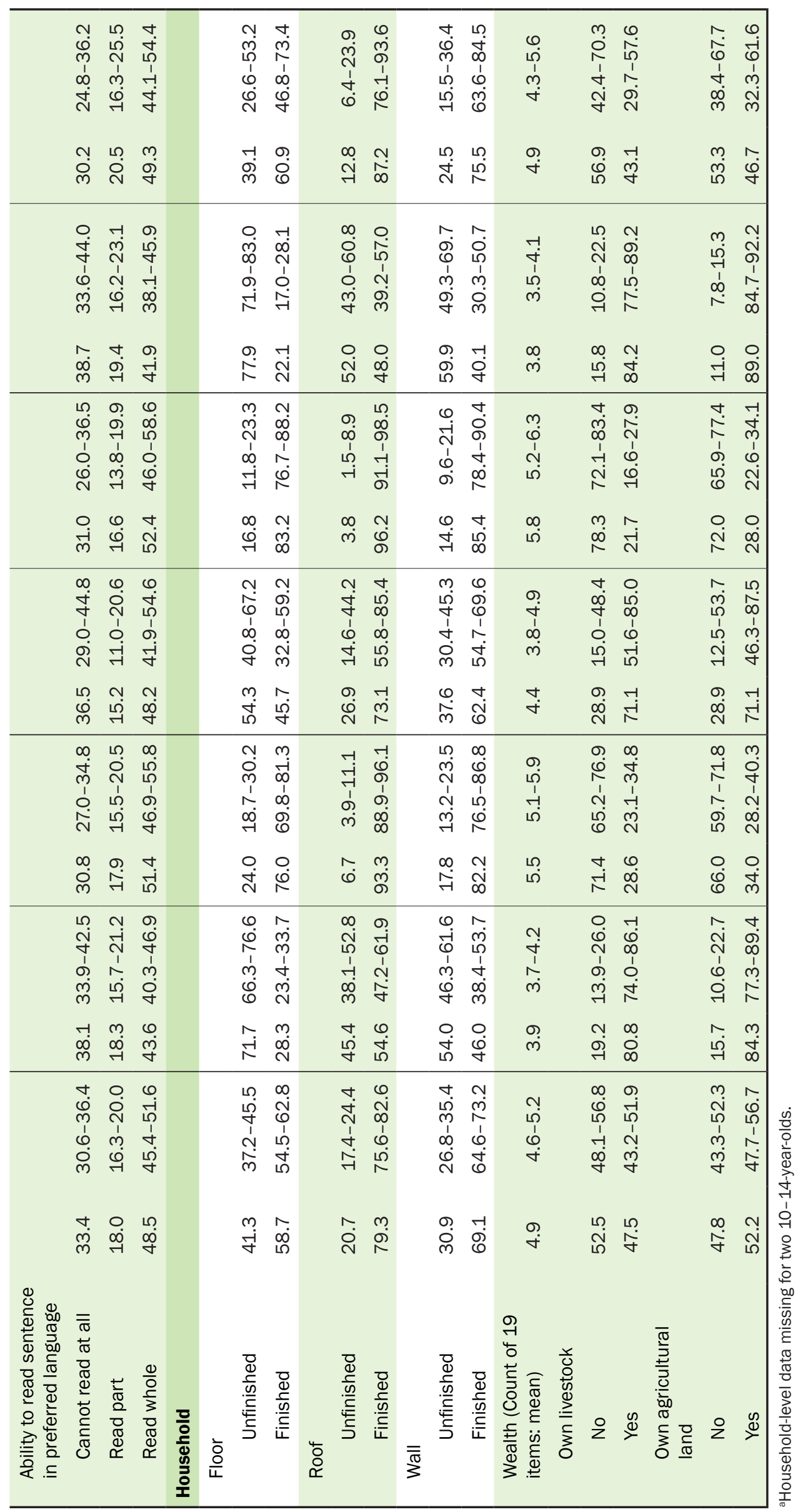


The mean age of the caregiver was quite high at 43 years of age, with urban areas having a mean age that was about three years older than rural areas. The high mean age of caregivers was driven by the substantial proportion of caregivers (32 percent) who were older than 50 years of age. These findings, as well as the high percentage of widowhood among caregivers (26 percent), has been documented in other studies of OVC in the region (Howard et al. 2006, Mishra and Assche 2008). In urban areas, there is a higher prevalence of older and widowed/widower caregivers compared with rural areas. In fact, the prevalence of widowhood in urban areas of the Central/Southern Provinces was more than double that observed in rural areas, while Lusaka/ Copperbelt Provinces had a 68 percent higher prevalence of widowhood in urban areas.

A significant percent ( 60 percent) of OVC caregivers were married or cohabitating with their spouse at the time of interview, although this percentage varied by area of residence. Marriage and cohabitation were higher in rural (72 percent) than in urban areas (50 percent), with a 12 percent difference in Lusaka and Copperbelt Provinces and an 18 percent difference in Central and Southern Provinces. A smaller percentage of caregivers were either never married (5 percent overall) or divorced/separated (9 percent) at the time of interview, with more modest differences in these statuses between urban and rural areas.

The overall mean years of schooling was 5.9 completed years, with marginally higher levels of years completed in urban areas (6.0 completed years). This mean indicates that caregivers on average completed approximately 84 percent of their primary school education or, in other words, that the average caregiver attended some primary school. Slightly more than one in 10 OVC caregivers had never attended school, with no differences in this indicator between rural and urban households. A quarter of caregivers had completed primary school, yet did not attend secondary school. While 22 percent of caregivers had attended secondary school, there was a drop-off in completing secondary school and moving onto higher education, with only 6 percent of caregivers completing secondary or higher. While there were some differences between urban and rural areas in educational completion, there was no clear pattern to be observed across the provinces.

Despite modest educational levels, a notable proportion of the Zambian caregiver population in these provinces had difficulty reading even a simple sentence in their local language. For instance, a large percentage of caregivers could not read at all (33 percent), with an additional 18 percent who had trouble reading a simple sentence. Reading levels were lower in rural areas, with the difference between rural and urban areas reaching 6 percent in Lusaka/Copperbelt and 8 percent in Central/Southern Provinces; Differences between urban and rural literacy were also similarly observed in the 2013-2014 ZDHS across residential areas (CSO, MOH, and ICF International 2014).

Overall, the housing quality indicators showed that a substantial percentage of OVC households relied on unfinished materials for their flooring, roof, and walls. The predominant of the three was unfinished flooring materials (earth, dung, wood, palm/bamboo), which was in use by around 40 percent of all OVC households. About one in three households had unfinished walls (cane/ palm/bamboo, mud, cardboard, plywood/used wood) and approximately one in five households had unfinished roofing materials (none, thatch/palm, rustic mats, palm/bamboo, wood planks, cardboard). As expected, the difference in housing quality indicators varied by residence, with 
OVC households in urban areas more likely to use finished materials relative to rural areas. These urban and rural differences were greatest in Central/Southern Provinces, although certainly prominent in Lusaka/Copperbelt as well.

Household assets represented a score of value for the household accumulated over time, reflecting the households' longer-term consumption of durable goods. Along with indicators of housing quality, asset indicators were a tool for capturing the relative economic position of the OVC household. Household assets also represent economic security, as they can be sold, loaned, or traded in exchange for cash or services. Table 6 provides the mean number of assets that were currently owned by OVC households on a scale that ranges from 0 to 19 assets. Overall, the OVC households had a limited mean number of assets, reflecting their low economic status and their relative insecurity in times of crisis. A good percentage of OVC households, however, did have productive assets in the form of ownership of livestock (48 percent) and agricultural land (52 percent), with variation across provinces and urban and rural residence.

\section{PEPFAR ESSENTIAL INDICATORS FOR OVC PROGRAMS}

A primary objective of PEPFAR-supported OVC programs is to collect and monitor PEPFAR's essential survey outcome indicators over time to measure the well-being of families and children that are directly affected by HIV. The essential indicators were collected to inform strategic and programmatic decision-making, as well as to guide resource allocation decisions within OVC programs and across other PEPFAR priorities and objectives (Measure Evaluation 2015b). As noted in Table 3, there are nine PEPFAR MER essential indicators. The data comprising these indicators have been collected in the ZAMFAM benchmark survey and are presented in Table 7. There are a total of seven MER essential indicators collected at the level of the OVC child and two indicators at the caregiver/household level. The essential indicators in Table 7 are disaggregated by age, where appropriate, and by urban and rural areas, as is recommended in PEPFAR guidelines (Measure Evaluation 2014a). Detailed tables with the essential indicators further disaggregated by IP, age, and urban/rural residences are provided in Appendix 3 (Tables 7 a and $7 b)$ for additional reference. 


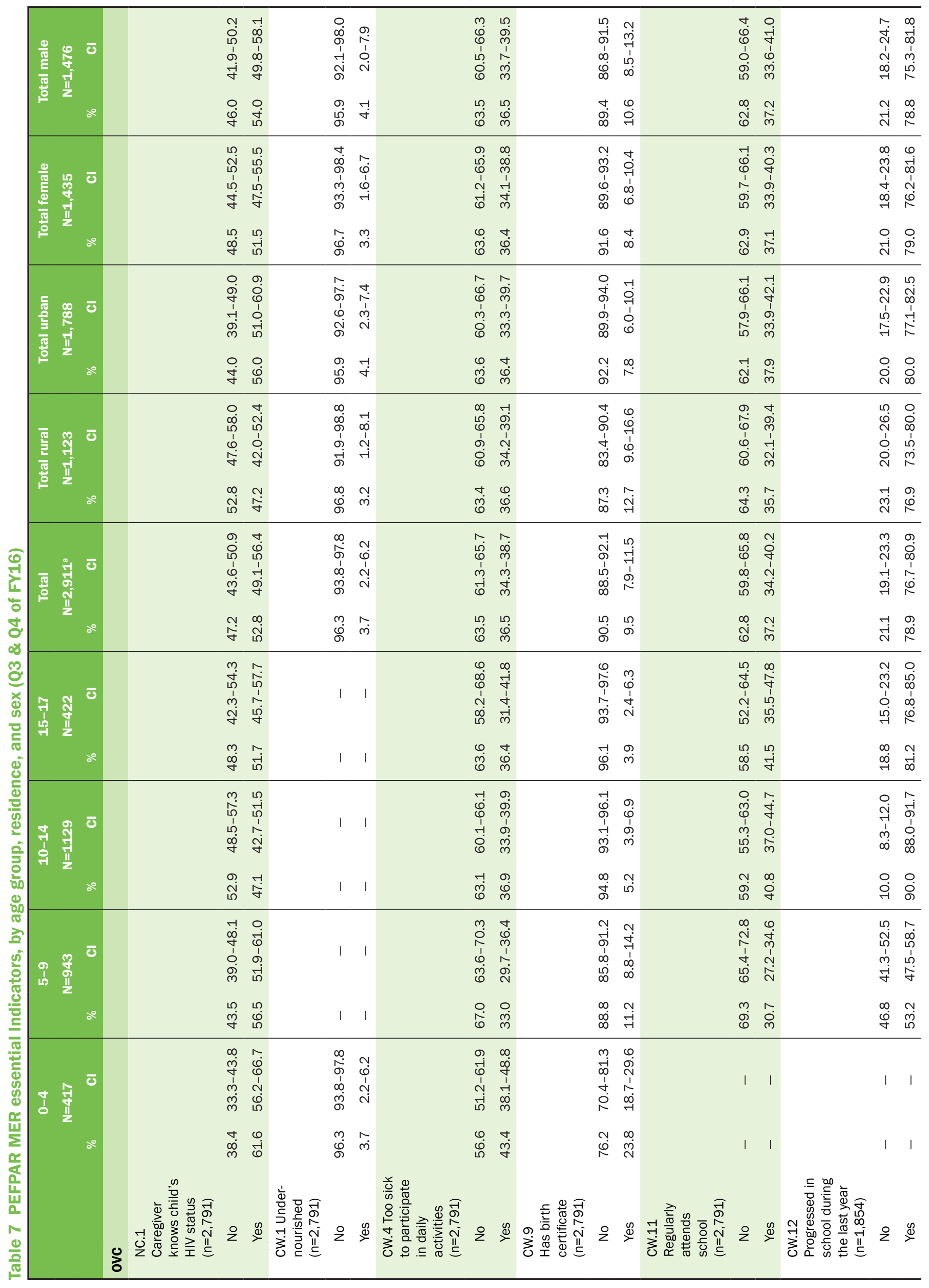




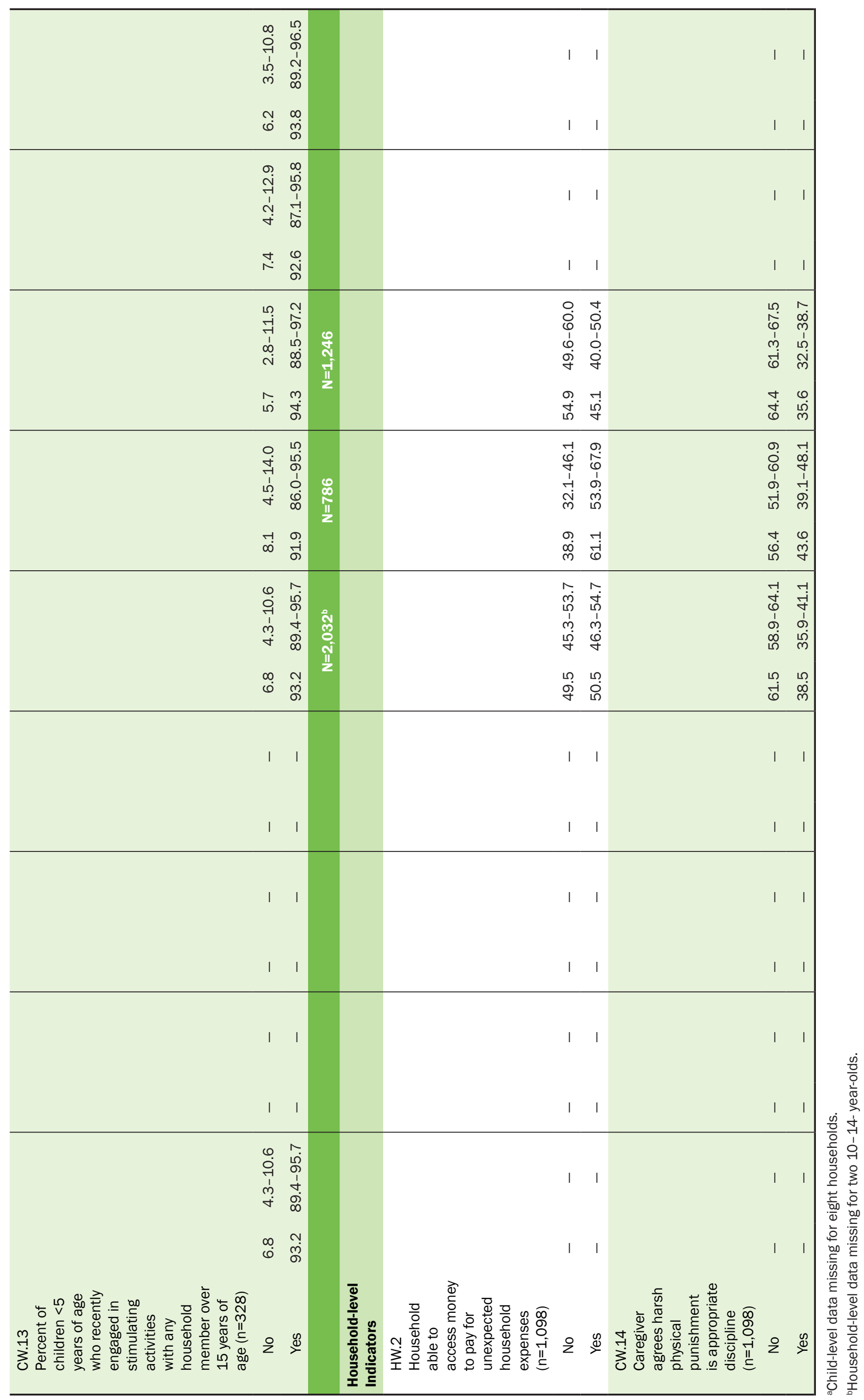


Essential indicator NC.1 (Knows child's HIV status): Knowing the child's HIV status is a critical first step in linking OVC to HIV prevention, care, and treatment programs and services (Measure Evaluation 2015b). In addition, Zambia's national HIV guidelines recommend HIV testing for all children and adolescents of unknown status through a family-based approach, irrespective of individual risk factors (Government of the Republic of Zambia (GRZ) 2014). In the benchmark data, just over half of OVC's HIV statuses were known by their caregivers. The percentage of children with known status was greatest for the youngest age group (62 percent) and lowest for OVC who were 10-14 years of age (47 percent). There was a modest gain in the known status of OVC aged 15-17 (to 52 percent), an age range in which sexual initiation and activity are increasingly common; 16 years of age is also when adolescents can obtain an HIV test without parental consent (GRZ 2011). For example, the ZDHS indicates that nearly one in five adolescent males aged 15-19 years had initiated sexual activity by age 15; by age 18, half of males had become sexually active (CSO, MOH, and ICF International 2014).

The HIV status of the child was also more likely to be known by the caregiver in urban areas than in rural areas, by approximately nine percentage points. This finding is not surprising, given the relative accessibility of health facilities and HIV testing points in urban areas. The fact that the difference was not greater suggests improvement in outreach of HIV testing and other HIV services to rural areas. For instance, by comparison, in 2005, only 25 percent of rural health centers offered HIV testing and counseling (HTC) services, compared with 88 percent of urban centers (MOH, CSO, and ORC Macro 2006). Differences also exist between known status for male and female OVC, with a slightly higher percentage of OVC caregivers knowing the status of male OVC. It should be noted, however, that this difference is not statistically significant.

The second essential indicator in Table 7, CW.1 (Undernourished), is the percent of children that were undernourished at the time of the survey. This indicator is recommended for collection for children less than five years of age (Measure Evaluation 2015b), and is measured anthropometrically using the MUAC. The indicator captures the reserves of muscle and fat in the body, which are depleted when a child is acutely or chronically undernourished. Undernutrition is indicated when the MUAC is $<125$ millimeters, as specified in PEPFAR guidelines (Measure Evaluation 2015b). Approximately 4 percent of OVC age 4 and under in the sample were undernourished at the time of the survey. This finding indicates low levels of undernutrition among OVC. A similar finding was observed in the 2011 Zambian National Nutrition Survey (ZNNS), which indicated undernutrition rates of less than 1 percent; it should be noted, however, that the ZNNS used a higher threshold for undernutrition, specifically 111 millimeters (GRZ 2008). Given the significant prevalence of stunting (25 percent) among children under five in Zambia (Richards and Bellack 2016)-reflecting longer-term accumulated impacts of undernutrition-this finding suggests that undernourishment is highly seasonal, occurring more often during the "lean season" between January and March (Fink, Jack, and Masiye 2016). Thus, the findings of low undernutrition during the benchmark survey may not be indicative of the needs of OVC at all times during the year. There were no meaningful differences in undernutrition between urban and rural areas, or between male and female OVC.

Essential indicator CW.4 captures the general health and well-being of children in their daily life (Measure Evaluation 2015b). A sizable percentage of OVC (37 percent) were reported by their caregiver (0-9 years) or by self-report (10-17 years) to have been too sick to participate in daily 
activities in the previous two weeks. The prevalence was greatest among the youngest children under five years of age (43 percent). However, reported sickness also occurred among more than one in three children across the remaining age groups. These findings are supported by data on reported bouts of diarrhea and fever in the previous two weeks for children under five years of age (CW.2 and CW.3, Table 8), revealing similar levels of prevalence as this indicator. There were no meaningful differences in the reporting of this indicator between urban and rural areas or by sex.

Issuance of a birth certificate (essential indicator CW.9) is a legal requirement for children in Zambia and considered by PEPFAR to be a critical indicator of the rights of the child and for establishing their right to access public services provided by the government, including health and education (Measure Evaluation 2015b). The data indicated that few OVC, specifically, one in ten, had a birth certificate. That said, there was more than a doubling of that percent among children aged 0-4 years, with 24 percent having been issued a birth certificate. This finding indicates significant recent efforts to bolster vital registrations at the time of birth (Tetra Tech ARD 2013). There were no meaningful differences in the reporting of this indicator between urban and rural areas for this population. A significantly higher percentage of males than females had a birth certificate (11 versus 8 percent, $p<0.05$ ).

Whether a child regularly attends school (essential indicator CW.11) and whether they had progressed in their education in the previous school year (essential indicator CW.12) indicate whether schools are successfully assuring that OVC are building the skills and abilities needed to be productive and to maximize positive health behaviors and outcomes. Unfortunately, a sizable percentage of OVC of all ages were missing these opportunities, with 63 percent of OVC not regularly attending school. Similar findings have been reported in the 2015 Zambia Living Conditions Monitoring Survey, which reported school attendance rates of the extremely poor to be lower than the moderately poor and the non-poor. For younger children aged 5-9 years, approximately 35 percent of OVC were not currently enrolled, with enrollment increasing with age (21 percent of this age group remained unenrolled by age 7 , the official start of primary school in Zambia). An additional 12 percent of OVC had enrolled, but did not attend, because they were unable afford school fees, materials, or transport to school. An additional 8 percent of OVC reported having missed school in the last school week due to sickness.

For older children 10-17 years, 59 percent reported not regularly attending school, with a slight difference between the younger (10-14 years) and the older (15-17 years) age groups. These similarities in irregular attendance hide differences in the underlying reasons for irregular/nonattendance. For younger OVC, it was because they have missed more school in the previous week relative to the older OVC (48 versus 41 percent), while for the older OVC, it was driven by a higher percentage of school drop-out (11 versus 24 percent). It is interesting to note that regular school attendance was nearly the same by residence, despite the greater distances to travel to primary and secondary schools in rural areas.

For those students enrolled in the previous school year, progression is very high for the older age group, reaching 90 percent among those 10-14 years of age (official school grades 4-8), but declining for the oldest OVC, largely due to school drop-out. Interestingly, there was little drop-off in progression or enrollment between ages 13 and 14, where children are transitioning between primary and secondary schools, though this finding is consistent with high transition 


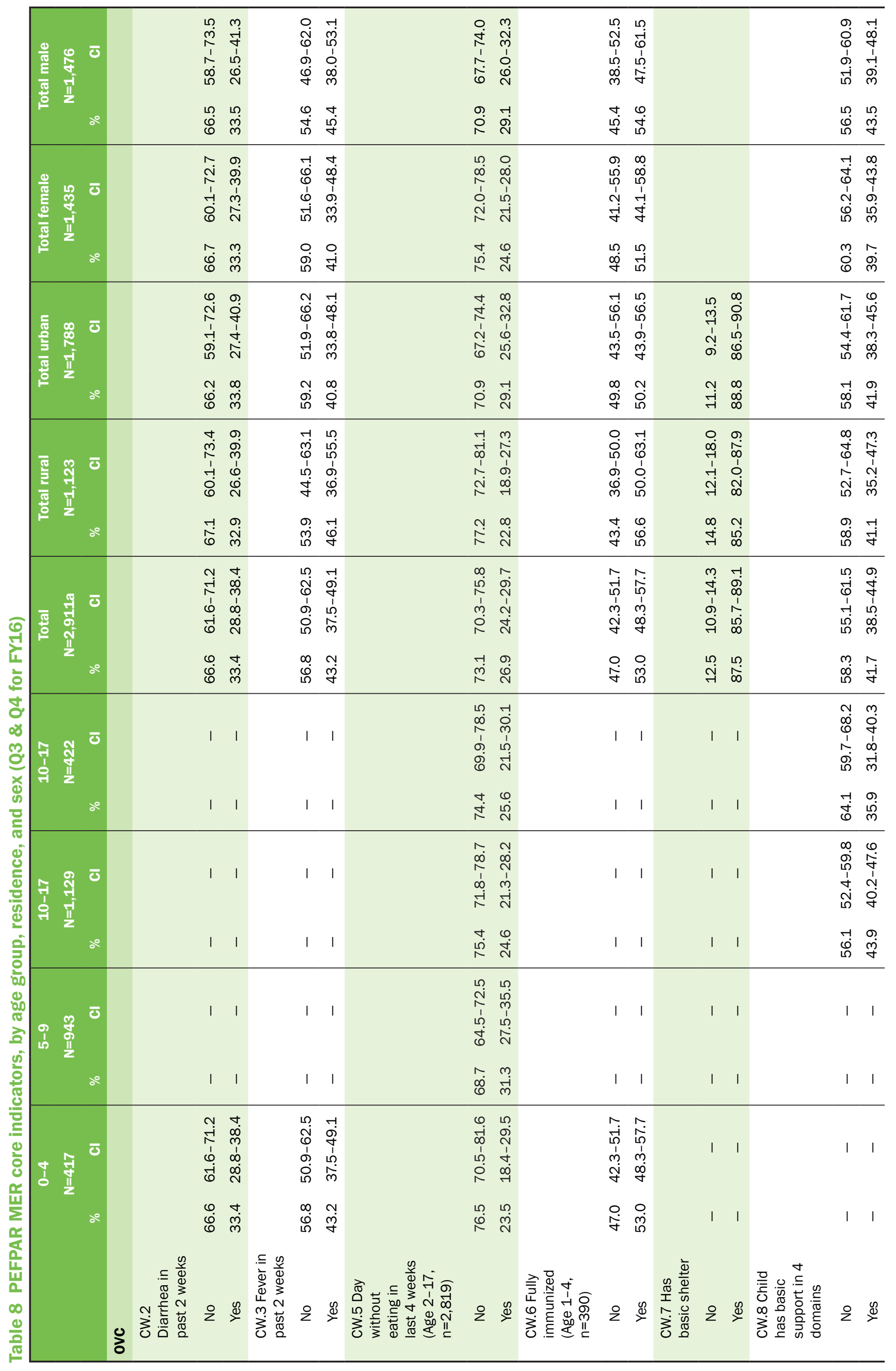




\begin{tabular}{|c|c|c|c|c|c|c|c|c|c|c|c|c|c|c|c|}
\hline & 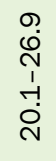 & 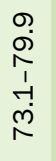 & & & 1 & 1 & & 1 & 1 & & 1 & 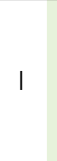 & . & & \\
\hline & $\stackrel{m}{\stackrel{m}{\sim}}$ & $\hat{\varphi}$ & & & 1 & 1 & & I & 1 & & 1 & I & & I & 1 \\
\hline & 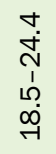 & $\begin{array}{l}L \\
\dot{1} \\
\infty \\
1 \\
6 \\
\stackrel{1}{1} \\
1\end{array}$ & & & 1 & 1 & & 1 & 1 & & 1 & 1 & & 1 & 1 \\
\hline & $\stackrel{m}{\stackrel{n}{\Delta}}$ & 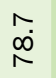 & & & 1 & 1 & & 1 & 1 & & 1 & 1 & & 1 & 1 \\
\hline & 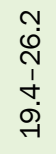 & $\begin{array}{l}0 \\
\dot{0} \\
\infty \\
1 \\
\infty \\
M \\
\end{array}$ & 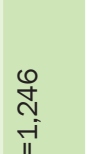 & & $\begin{array}{l}\qquad ? \\
0 \\
\llcorner \\
1 \\
1 \\
\infty \\
\infty \\
+\end{array}$ & 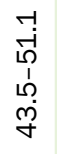 & & $\begin{array}{l}0 \\
\infty \\
0 \\
1 \\
\infty \\
0 \\
10 \\
\infty\end{array}$ & $\begin{array}{l}\text { N } \\
\text { I } \\
\vdots \\
\vdots \\
\stackrel{n}{j}\end{array}$ & & \begin{tabular}{l}
$\infty$ \\
$\stackrel{\infty}{ }$ \\
$\stackrel{1}{1}$ \\
\multirow{1}{*}{} \\
1 \\
0
\end{tabular} & $\begin{array}{l}\infty \\
\dot{j} \\
1 \\
\stackrel{1}{~} \\
\dot{\sim}\end{array}$ & & 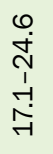 & 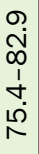 \\
\hline & $\begin{array}{l}0 \\
\stackrel{N}{N}\end{array}$ & 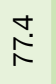 & & & ત્ડ & $\stackrel{\stackrel{m}{\sim}}{\stackrel{f}{*}}$ & & ત્ત & $\begin{array}{l}\stackrel{\leftrightarrow}{\dot{m}} \\
\text { }\end{array}$ & & $\begin{array}{l}\infty \\
\stackrel{\infty}{\Gamma} \\
\stackrel{2}{2}\end{array}$ & $\begin{array}{l}\text { N̦ } \\
\text { Nิ }\end{array}$ & & & ণ্ণ \\
\hline & $\begin{array}{l}0 \\
\dot{0} \\
N \\
1 \\
0 \\
\infty \\
+1\end{array}$ & $\begin{array}{l}0 \\
\text { i } \\
\infty \\
1 \\
0 \\
\dot{1}\end{array}$ & 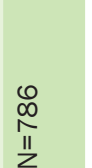 & & $\begin{array}{l}r \\
\infty \\
\infty \\
1 \\
1 \\
m \\
\infty \\
+\end{array}$ & $\begin{array}{l}\hat{0} \\
0 \\
1 \\
1 \\
0 \\
\dot{\gamma}\end{array}$ & & 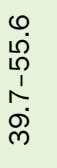 & $\begin{array}{l}m \\
0 \\
0 \\
1 \\
1 \\
\dot{j} \\
\dot{y}\end{array}$ & & $\begin{array}{l}1 \\
\text { i̊ } \\
0 \\
1 \\
0 \\
-1 \\
\text { i் }\end{array}$ & 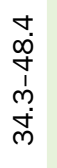 & & 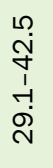 & 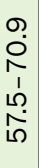 \\
\hline & $\stackrel{\infty}{\stackrel{\leftrightarrow}{\mathrm{d}}}$ & $\underset{\substack{\infty \\
\perp}}{\stackrel{\infty}{\wedge}}$ & & & 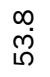 & 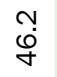 & & $\begin{array}{l}\stackrel{\varphi}{\sim} \\
\stackrel{+}{*}\end{array}$ & ત્ণ & & $\begin{array}{l}\stackrel{\infty}{\infty} \\
\stackrel{\circ}{\circ}\end{array}$ & $\underset{\forall}{\vec{y}}$ & & & $\begin{array}{l}\text { L } \\
\mathbb{0}\end{array}$ \\
\hline & $\begin{array}{l}\stackrel{-1}{1} \\
\stackrel{1}{N} \\
1 \\
\infty \\
\stackrel{9}{7}\end{array}$ & 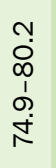 & $\begin{array}{l}\text { त̃ } \\
\text { Oे } \\
\text { Ni } \\
\|\end{array}$ & & $\begin{array}{l}\circ \\
0 \\
10 \\
1 \\
1 \\
0 \\
0\end{array}$ & $\begin{array}{l}\infty \\
\stackrel{\infty}{+} \\
\stackrel{+}{1} \\
\vdots \\
\dot{+} \\
\dot{f}\end{array}$ & & 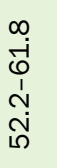 & $\begin{array}{l}\infty \\
\stackrel{\infty}{+} \\
\stackrel{1}{1} \\
\sim \\
\infty \\
m\end{array}$ & & 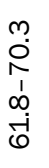 & 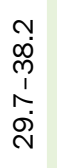 & & $\begin{array}{l}0 \\
\stackrel{0}{ } \\
\text { I } \\
\hat{N} \\
\text { N }\end{array}$ & 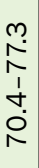 \\
\hline & $\stackrel{\text { }}{\stackrel{N}{N}}$ & $\stackrel{\hat{\Gamma}}{\stackrel{r}{r}}$ & & & ウ̊. & $\begin{array}{l}\stackrel{o}{0} \\
\dot{q}\end{array}$ & & $\stackrel{-1}{\stackrel{1}{n}}$ & $\stackrel{\stackrel{\leftrightarrow}{\sim}}{\text { }}$ & & $\begin{array}{l}\text { N } \\
\ddot{\theta}\end{array}$ & $\stackrel{\infty}{\infty} \underset{m}{\infty}$ & & & $\begin{array}{l}\circ \\
\stackrel{N}{N}\end{array}$ \\
\hline & \begin{tabular}{l}
$\hat{N}$ \\
$\infty$ \\
\multirow{1}{1}{} \\
$\vdots$ \\
$i$ \\
$i$
\end{tabular} & 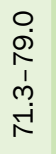 & & & 1 & 1 & & 1 & 1 & & 1 & 1 & & 1 & I \\
\hline & $\begin{array}{l}\stackrel{0}{+} \\
\stackrel{+}{N}\end{array}$ & ஜே & & & 1 & I & & I & I & & 1 & I & & I & 1 \\
\hline & \begin{tabular}{l}
$\stackrel{-}{+}$ \\
\multirow{+}{1}{} \\
$\stackrel{1}{\sim}$ \\
$\sigma$
\end{tabular} & $\begin{array}{l}\infty \\
\stackrel{0}{0} \\
1 \\
1 \\
\infty \\
\infty \\
\infty\end{array}$ & & & 1 & I & & I & I & & 1 & 1 & & 1 & 1 \\
\hline & ت্ & $\begin{array}{l}0 \\
\infty \\
\infty\end{array}$ & & & 1 & I & & I & I & & 1 & 1 & & 1 & 1 \\
\hline & $\begin{array}{l}0 \\
\infty \\
\infty \\
m \\
m \\
m \\
\dot{m}\end{array}$ & $\begin{array}{l}\hat{0} \\
0 \\
1 \\
-1 \\
-1 \\
-1\end{array}$ & & & 1 & I & & I & 1 & & 1 & 1 & & 1 & 1 \\
\hline & 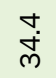 & $\begin{array}{l}0 \\
\dot{0} \\
\dot{0}\end{array}$ & & & I & 1 & & 1 & I & & 1 & 1 & & 1 & 1 \\
\hline & 1 & I & & & I & I & & 1 & 1 & & 1 & I & & 1 & 1 \\
\hline & 1 & 1 & & & 1 & 1 & & 1 & 1 & & 1 & I & & & 1 \\
\hline 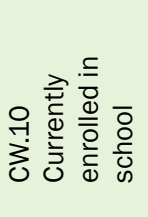 & 운 & $\stackrel{\infty}{\rightleftharpoons}$ & 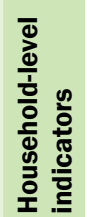 & 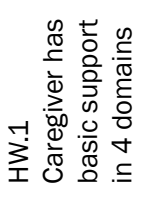 & 운 & $\stackrel{\mathscr{D}}{\rightleftharpoons}$ & 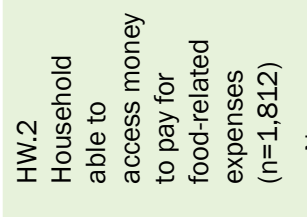 & o & $\stackrel{\infty}{=}$ & 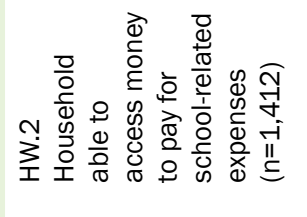 & 운 & $\stackrel{\infty}{\rightleftharpoons}$ & 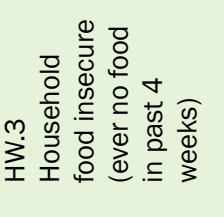 & 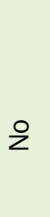 & $\stackrel{\mathscr{D}}{\nu}$ \\
\hline
\end{tabular}

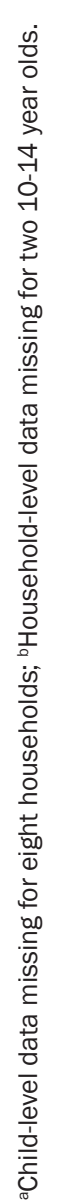


rates between grades 7 and 8 observed in the general population in Zambia (Ministry of Education Science Vocational Training and Early Education 2014). The progression for younger OVC, 5-9 years of age, was less positive and more complex. Only 53 percent of the younger OVC were reported to have attended school the previous year and progressed in the current year. Additionally, there existed a steep gradient of progression from 33 percent for 5-year-old OVC to 66 percent for 9 -year-old OVC; by age 10, nearly 90 percent reported having progressed. The data do not provide a clear explanation, but it is possible that the progression gradient is the result of poorer students leaving school altogether as their better performing peers move on through the grades. As with other indicators, there was little difference in progression by residence or by sex.

Essential indicator CW.13 measures the percentage of the OVC population under the age of five years who have interacted with adult members of the household in stimulating activities. Such activities are considered critical for promoting the development, health, and well-being of OVC and for fostering their cognitive, emotional, and physical development (Measure Evaluation 2015b). Activities measured in the benchmark survey included reading or looking at books; being told stories; singing songs; playing, counting, or drawing; or taking the child outside the home or compound. The data indicated that 93 percent of OVC aged 5 years or younger were reported by the caregivers as having been exposed to stimulating activities in the last three days. Although all specific activities were mentioned by at least 20 percent of the OVC's caregivers, the two most predominant activities were reading books (54 percent) and/or telling stories (41 percent). Whereas a marginally higher percentage of OVC were reported to engage in such activities in urban areas compared to rural, the difference was not statistically significant. There were no meaningful differences between boys and girls in their exposure to engagement with adults in stimulating activities.

The final two PEPFAR essential indicators are measured at the caregiver or household level. The first (essential indicator HW.2) captures whether the household had access to money to pay for unexpected household expenses or for medical treatment. As noted by PEPFAR, the HW.2 indicator "is a direct measure of a household's financial stability and resilience in the face of economic shocks" and captures the vulnerability and financial stability of the household that OVC programs are directed to improve (Measure Evaluation 2015b). It should be noted, however, that the indicator is retrospective in nature; it is measured only if the household had, in fact, an unexpected expense in the past 12 months. The indicator likely underestimates the true extent of economic vulnerability of households, as significant proportions of households who are vulnerable may not have faced unexpected economic expenses in the past 12 months, but could in the future and may not have sufficient resources to adjust, particularly if there were local or national economic, social, political, or environmental setbacks.

With this caveat in mind, approximately 50 percent of OVC households could not draw upon resources to protect them when faced with an unexpected expense in the previous 12 months. This percentage varied significantly between rural and urban areas, with OVC households located in the latter significantly more likely to be economically vulnerable and lacking an asset base to draw upon in times of crisis (61 versus 45 percent, $p<0.001$ ). The 16-percentage-point difference between rural and urban households is notable. Rural and urban households were much less differentiated by whether they had had, in fact, faced an unexpected expense in the previous 12 months (50 percent and 56 percent, respectively). Rural OVC households more often addressed 
an unexpected economic event by using current income, savings, and solid assets (crops, animals, charcoal), while urban households more often relied on loans, gifts, and piecemeal labor.

The final OVC essential indicator CW.14 measures whether caregivers agree that harsh physical punishment in the home or at school is an appropriate form of discipline. Studies have indicated that harsh discipline can have negative developmental consequences for children and lead to adverse mental health and behavior in adolescence (Bender et al. 2007). Despite the fact that corporal punishment was outlawed in Zambia over a decade ago, a high proportion of OVC caregivers (39 percent) supported harsh physical discipline of children. These data suggest that the traditional norm of physical punishment cannot solely be addressed through changes in the legal framework, but requires community normative behavior changes as well. The percentage of caregivers supporting harsh physical punishment was higher in rural compared with urban areas (44 versus 36 percent, $p<0.01$ ).

\section{ADDITIONAL PEPFAR CORE INDICATORS FOR OVC PROGRAMS}

Six of the nine PEPFAR MER essential indicators discussed previously were selected from a broader set of 15 PEPFAR core OVC impact indicators originally developed for OVC programs (Measure Evaluation 2014b). An additional three essential OVC indicators were added in updated monitoring guidelines (Measure Evaluation 2015b). Table 8 presents the additional core indicators included in original guidance documents that are not considered essential indicators per se. Appendix 4 (Tables $8 a$ and 8b) present these core indicators separately for ECR and DAPP implementing provinces. As with the PEFPAR essential indicators, these indicators are measured at the child and household level. The child indicators presented in the table cover areas of OVC health (diarrhea, fever, immunization), nutritional intake, shelter, emotional and social support, and school enrollment, while the household indicators cover caregiver support and economic insecurity.

Of interest in Table 8, more than one in four OVC children between the ages of 2 and 17 years were reported to have not eaten any food for at least one whole day and night in the last four weeks; identical levels of lack of food were also observed at the household level (HW.3). Although this reported lack of food in the household did not translate into children meeting anthropometric standards for undernutrition using the MUAC measurement (as noted previously), it does indicate intermittent food insecurity in the household, even in seasons when food availability is greater and costs lower. Food vulnerability was also reflected in the household-level indicator HW.2, which revealed that more than half of households (57 percent) did not have access to resources to cover food-related expenses incurred in the previous four weeks. The data also indicate that urban compared to rural OVC were significantly more likely to report irregular food intake, with the rural/urban divide being even greater for HW.2 (48 versus 62 percent, $p<0.01$ ) and HW.3 (65 versus 79 percent, $p<0.001$ ).

Child immunizations against tuberculosis, diphtheria, pertussis, tetanus, polio, and measles is crucial to reducing infant and child morbidity and mortality, and all children should receive these 
immunizations prior to one year of life (CSO, MOH, and ICF International 2014). The benchmark data indicate that 47 percent of OVC aged 1-4 years had not been fully immunized by their first birthday. This percentage was higher than the 43 percent of similarly aged children not fully immunized reported in the 2013-2014 ZDHS (CSO, MOH, and ICF International 2014). It should, however, be noted that the ZDHS statistic is within the confidence interval of the benchmark estimate. Although there were substantive differences between urban and rural OVC, and between males and females for this indicator, the differences were not statistically significant, potentially due to smaller sub-sample sizes.

OVC aged 10-17 years of age were asked about the emotional and social support they receive, either from members of their own household or other people in their community. This indicator is measured as whether they have someone to discuss personal problems with, someone who shows love and affection, someone who can help with chores when they were sick, and someone to do enjoyable things with. The benchmark data indicate that a very large proportion of adolescent OVC (58 percent) have a gap in one of these areas of critical needs in their lives, with some indication that this may be more of an issue for girls than boys, although the difference by sex was not statistically significant. It is interesting to note that caregivers also reported similarly large gaps in social and emotional support as OVC (HW.1). The largest gaps for adolescent OVC were in two of the more critical indicators; specifically, 40 percent reported that they do not have someone to discuss personal problems and 23 percent reported they do not have someone who shows them love and affection. On a more positive note, only under 1 percent of the sample of adolescent OVC (data not shown) indicate that they were lacking support across all four indicators, suggesting that at least some aspects of their social and emotional needs were being met. 


\section{DISCUSSION}

USAID is supporting the ZAMFAM) project to strengthen comprehensive, integrated service delivery and support to children living with, affected by, or vulnerable to HIV/AIDS. ZAMFAM is providing child- and family-focused services, including community-based child welfare support and sustainable delivery of a full array of services needed for families. The goal of ZAMFAM is to improve the care and resilience of OVC and their households in the four target provinces that were the focus of this benchmark survey assessment.

The PEFPAR MER essential indicators and the broader set of core indicators that are discussed in this benchmark report provide a basis for assessing the current status, circumstances, and service gaps of OVC families, as well as a potentially useful tool for monitoring and evaluation programs (by observing change in the indicators over time). The findings generated by the benchmark assessment provide a basis for enhanced action for addressing the needs of OVC and their caregivers. This report provides evidence to support policy options and guides programming in linking essential interventions to gaps in service delivery, and highlights the need to strengthen ongoing program interventions.

\section{LIMITATIONS}

The benchmark assessment is a cross-sectional survey capturing the status and conditions of OVC households at one point in time. As such, it is not possible to draw firm conclusions about the progress that has been made in the PEPFAR OVC essential indicators. For instance, while large gaps may suggest a grim picture of need, trend data may indicate broad progress among OVC families from government or donor activities. As the benchmark data are derived from a rather unique OVC sample, it is difficult to compare with national surveys, such as the Demographic and Health Surveys. Besides not including a sub-sample of OVC households, the 2007 ZDHS data has only a limited selection of indicators that are directly comparable to the PEPFAR essential or core indicators

The indicators in the benchmark assessment were collected via a survey instrument based on self-report of either the guardians or the OVC (aged 10-17). Given this fact, there are a few foreseeable potential biases that may arise. For instance, individuals may have overstated the need and understated their household and individual well-being in the hopes that the assessment would lead the government or other entity to provide more material support for their household or community. These biases would likely be greatest for measures of economic or food security of the household. On the other hand, it is also possible that guardians will underreport negative behavior (harsh physical punishment or abuse, keeping kids out-of-school) or household conditions (food insecurity, undernutrition) among the youngest OVC (aged 0-9 years) due to embarrassment, fear of stigmatization, or even legal reprisal from the community or government. If these reporting issues are prevalent, then OVC may have even poorer statuses than is reported in the benchmark assessment. 
Finally, PEPFAR's essential indicators measuring economic and food insecurity likely underestimate the true level of household insecurity, particularly in the case of significant local or national economic, social, political, and/or environmental shocks. The measure is constructed from a set of questions that are established upon whether the household had experienced a shock in the previous 12 months. Thus, it does not capture the security of households that had not experienced any retrospective event, but would be unfavorably positioned to face any significant adverse event in the future. Given the high prevalence of insecurity found among OVC households in the benchmark assessment, the "missing households" in this measure would suggest even a greater attention to this issue in OVC programming. 


\section{CONCLUSIONS AND RECOMMENDATIONS BY INVESTIGATORS}

The benchmark study assessed the status and circumstances of OVC using the PEPFAR MER essential indicators for OVC programs, as well as other program indicators as defined in the study objectives. Some broad conclusions and recommendations can be drawn even from the limited analysis of the benchmark assessment and MER indicators conducted.

- A large percentage of OVC caregivers were older women with little or no formal education. Further, a significant percentage of OVC caregivers could not read even simple sentences in their local language or in English, and had limited access to modern media. These findings suggest that OVC programs should consider the specific needs of older women as caregivers to OVC. Such women need to maintain their own health, capacities, and economic productivity as they age. They were also in need of socio-emotional support, as significant percentages of caregivers reported that they did not have access to a confidant to share personal problems with. These findings also imply that OVC families need assistance and guidance linking to and accessing public services, whether they are health, educational, or legal. In addition, preparation and planning for succession of care need to be considered by families to assure continuity of care and guardian support for OVC.

- Zambia's national guidelines prescribe HTC for all children and adolescents whose status is unknown. As revealed in the benchmark survey, nearly half of OVC children had an HIV status that was unknown by their caregiver. As OVC have already been affected in some way by HIV or are at heightened risk of HIV acquisition as they transition to late adolescence, the goal of linking OVC to family- and household-based HTC remains a gap to be addressed by OVC programs and services. If the gap between universal testing of children and current testing rates is closed as a first step, particularly for these high-risk families, it is more likely the 9090-90 targets can be met and the impact of the epidemic lessened, especially for the most atrisk girls and young women.

- The benchmark data summarizing undernourishment in the sample based upon the MUAC of the child indicates a rather favorable situation for the majority of young OVC in Zambia, with few children meeting the threshold of undernourishment at the time of the survey. That said, high prevalence of stunting among children and adolescents found in multiple recent surveys and studies in Zambia suggests that chronic undernutrition is a critical concern. The findings presented here need to be balanced by the fact that the data were not collected during the "lean" season in which food scarcity is greatest (January through March). Additionally, multiple indicators of household food insecurity suggest that, even in times in which food availability is greatest and food costs are lowest, a large percentage of OVC and their family members go without meals at times during the month. The benchmark data summarizing economic security-e.g., in the form of household assets, animals, or crops-also suggest limited household reserves (particularly in urban areas) to offset economic and/or other shocks 
that impact nutritional intake. Sustainable approaches to assuring continuous food supplies, agricultural production, and animal husbandry should be considered by OVC programs. The findings here also call for more regular assessment of nutritional status of OVC families across the months and seasons.

- Health is a critical concern for OVC programs, and children being too chronically ill to participate in daily activities is suggestive of developmental delays and poor well-being, as well as potential for deleterious impacts on educational outcomes and household production. OVC programs should provide a critical linkage to health services and treatment, while addressing exposure to pathogens in the household and community. Such activities can reduce the number of sick children and improve functional well-being of OVC. The percentage of children in the benchmark survey who were reported to be too sick to participate in daily activities was high. These results are supported by other indicators that show that bouts of diarrhea and fever are common among OVC, suggesting exposures to infectious disease and unsanitary conditions, compounded by potentially poor nutrition. These data suggest that OVC families should be exposed to hygiene through WASH programs. Further, significant gaps exist in the rates of immunization of the youngest OVC for preventable diseases, suggesting the need for the youngest OVC to be linked to maternal and child health clinics during the first year of life to obtain the requisite vaccinations for preventable diseases.

- Despite efforts by the government and partners such as PEPFAR, the number of children who had a birth certificate was less than one in ten. Ensuring children have birth certificates enables them to access essential services and opportunities, including health, education, legal services, and legal employment at older ages. Although the challenge is formidable with respect to achieving the goal of universal provision of birth certificates, the benchmark survey did indicate that rates have doubled across the youngest age groups (albeit from a low starting point), at least suggesting recent successes in increasing the provision of birth certificates. Monitoring of this indicator for continual expansion of the availability of birth certificates among OVC is warranted.

- The PEPFAR essential indicator for whether OVC regularly attend school reveals a significant challenge ahead for maximizing the potential of schooling for children. While the indicator potentially overestimated non-attendance for the youngest school age group (5-9 years), as Zambia's official starting age is seven years, there remained a significant percentage of children who did not regularly attend at age seven or older. A good portion of the non-attendance was due to missing days of school in the previous week (e.g., due to sickness), but the majority were children who are not enrolled or who had left school, often reportedly for lack of school fees, uniforms, or materials. If children did remain in school, progression from year-to-year was quite high, potentially due to selection of the most able students. Further, differences between OVC boys and girls regarding either attendance or progression were minimal.

- Household economic strengthening programs are key to improving household resilience and poor social/economic outcomes and challenges, including those from unexpected or emergency expenses. The percentage of OVC households that had access to money to pay for unexpected household, food-related, or school-related expenses was quite low. Additionally, the socioeconomic indicators suggested that OVC households have few fixed assets to draw upon in times of economic shocks. Economic and food insecurity was more prevalent in urban households where crops and livestock were not as readily available; it also suggests 
underemployment within OVC households. The lack of economic and labor data on caregivers and OVC in the benchmark study limits the ability to fully explore the productive capacity and employment status of the households. This suggests that a more detailed assessment of household production would be informative to further improve OVC programming.

- Parenting practices are an area for future programming, considering the significant impact that parents and guardians may have on the social, emotional, and cognitive development of children. The benchmark data indicate some important findings. Most of the youngest OVC children (aged $<5$ years) were exposed to engaging and stimulating activities by adult members of the household. Whereas this might suggest a lack of need for further program improvement in this area, there is limited information on the quality and impact of such activities. In addition, parents-particularly in rural areas-supported harsh physical punishment in disciplining children. This normative perspective does not mesh with the evidence that suggests such parenting behaviors are counterproductive and lead to adverse socio-emotional development. The data also suggest that socio-emotional needs of OVC adolescents need to be considered, as a substantial proportion of OVC adolescents did not feel that they have confidants or someone who provides them love and affection. This latter finding may suggest room for programs directed toward improving parental-child interactions and communications within the household, as well as mentor programs external to the household. 


\section{FOLLOW-UP ACTIONS PROPOSED BY IMPLEMENTING PARTNERS (RESEARCH UTILIZATION)}

The benchmark study assessed the status and circumstances of OVC using the PEPFAR MER essential indicators for OVC programs, as well as other program indicators as defined in the study objectives. These data were shared with IPs and also presented to the research technical advisory group that included the two IPS-DAPP and ECR-who expressed views on how they will utilize the findings of the benchmark survey in program implementation, as illustrated by the comments below:

Finding: A large percentage of OVC caregivers were older women with little or no formal education. Further, a significant percentage of OVC caregivers were not able to read even simple sentences in their local language or in English, and have limited access to modern media.

Comments from IPs:

"Caregivers of OVC are the primary providers of psychosocial support to OVC. Therefore, their own psychosocial well-being is of paramount importance. ZAMFAM will, through trained community volunteers, enhance the assessment of social, psychosocial, and emotional needs of caregivers of OVC and provide a comprehensive range of services to address the identified needs (e.g., bereavement support, general counseling, etc.). ECR will strengthen support groups created from previous programs and create new ones to create a platform for caregivers to give and receive support from one another. Such interactions will create strong and trusting relationships that will encourage sharing of personal problems. ECR will further engage churches to create deliberate programs to address the social and emotional needs of older caregivers of OVC. Through available community service maps and databases, community volunteers will guide and link OVC households to health, educational, or legal services. ECR will continue strengthening linkages and collaborations with public structures to facilitate referrals of OVC families to public services. ZAMFAM will continue supporting succession planning by helping OVC families to identify trusted and willing family members who can continue providing care to OVC in the event of death or illness of a primary caregiver, and tracing of lost relatives to ensure continuity of care and support for OVC." 
Finding: Nearly half of OVC's HIV status was unknown by the caregiver.

Comments from IPs:

"Need to strengthen linkages with more testing and treatment partners to promote synergy. It is one thing for OVC and their families to know their HIV status, but another for them to know where to access antiretroviral therapy and have the actual service. Hence the different strengths from both community-based partners on one hand, and testing and treatment partners on another, would ensure an integrated and holistic approach towards improving the welfare of OVC."

"A number of families have a problem with disclosure of HIV-positive children or enabling these children to access antiretroviral therapy, and some of those who do have a challenge in terms of adherence. Therefore, they need encouragement in order for them to actively participate in pharmacovigilance."

"ZAMFAM will train lay counselors to conduct home-based index case HIV testing to reach children and adolescents with unknown HIV status to contribute to the UNAIDS 90-90-90 goal, which stipulates that 90 percent of those who are HIV-positive know their HIV status, 90 percent of those who are HIV-positive access treatment, and 90 percent of those on treatment have their viral load suppressed. In order to ensure quality of HIV testing services, ZAMFAM will train lay counselors using an approved GRZ [Government of the Republic of Zambia] curriculum and will receive ongoing mentorship. ZAMFAM will strengthen linkages and referral networks between ART providers and communities to support the continuum of care for HIV-positive children. Through periodic meetings, health facilities and community-based and faith-based organizations will establish better ways of ensuring access to pediatric ART care (retention in care, follow-up mechanisms, family/ caregiver involvement, ART adherence) and pre-ART for those over age 15. ZAMFAM will pay special attention to strengthening referral networks for adolescents to access pre-ART and ARV treatment (both during adolescence and in transition to adult care services). HIVinfected children and caregivers will be provided with transportation assistance (where necessary) to keep clinic appointments and access other health services. Through trained community volunteers, HIV-positive children and their caregivers will receive supportive services such as help with disclosure, ART adherence, and stigma and discrimination concerns. Parents will also be engaged in pediatric and adolescent (below the age of 18 years) HIV education using standardized training. Economic support services (such as community savings groups) will target households with children living with HIV to enable them meet the basic needs of these children." 
Finding: Multiple indicators of household food insecurity suggest that, even in times in which food availability is greatest and food costs are lowest, a large percentage of OVC and their family members go without meals at times during the month. The benchmark data summarizing economic security also suggest limited household reserves.

Comments from IPs:

"ZAMFAM will continue to strengthen the technical capacity of community-based and faith-based organizations and community volunteers to provide nutrition services in line with GRZ service standards. Trained community volunteers will share basic health education through home visits and conduct routine (at least every six months) screening of the nutritional status of children aged 0 to 15 through anthropometric assessments (e.g., MUAC) and provide referrals as needed. ZAMFAM will further link with other USAIDPEPFAR partners and other stakeholders in the target communities to leverage existing nutrition interventions such as supplementary feeding for undernourished OVC. Through public-private partnerships initiatives, ZAMFAM will leverage support for OVC households to promote economic security (household assets, crops, animals) to make OVC households resilient in the face of shocks that hamper nutritional intake."

Finding: The percentage of children in the benchmark survey who were reported to be too sick to participate in daily activities was high. Further, significant gaps were observed in the rates of immunization for preventable diseases among the youngest OVC.

Comments from IPs:

"ZAMFAM will strengthen partnerships/relationships among churches, schools F/CBOs, and GRZ health facilities to maximize benefits in child health (immunizations, management of illness, vitamin supplements). ZAMFAM community volunteers will, through home visits, provide health education (basic personal hygiene, promote clean home environments, management of minor illnesses, e.g., diarrhea) in order to reduce infections in children and improve functional well-being."

Finding: Fewer than one in ten children had a birth certificate.

Comments from IPs:

"Decentralization of this function and involvement of more players with interest and influence would assist, e.g., local authorities work closely with all relevant government line ministries. Monitoring of this indicator for continual expansion of the availability of birth certificates among OVC is warranted."

"ECR through previous programs trained many community volunteers who supported birth registration for OVC. However, due to some challenges that exist within the GRZ department responsible for birth registration, issuance of birth certificates takes a long time. ZAMFAM will follow up the issuance of birth certificates for children who transitioned to ZAMFAM from STEPS-OVC. ECR will further train more community volunteers to facilitate 
birth registration for OVC in collaboration with the Department of National Registration, Passports and Citizenship under the Ministry of Home Affairs. Through home visits, trained community volunteers will intensify awareness on the importance of birth certificates, such as enabling a child to access basic rights (enjoy child-friendly treatment within justice systems when in contact or conflict with the law; protection from child labor, early marriages, and trafficking), and access social services including immunization, health care, and schooling."

Finding: The PEPFAR essential indicator for whether OVC regularly attend school reveals a significant challenge ahead for maximizing the potential of schooling for children.

Comments from IPs:

"There are more factors that cause absenteeism and eventual drop-out of school, especially for female OVC, which should be addressed. These include girls being the ones taking care of siblings and sometimes ailing members of the families, including parents/ guardians. Lack of or inadequate sanitation facilities keep girls away from school. There is need to address not only issues that keep them away from school, but also if they are retained in school, ways for them to catch up on school work so as to attain quality education. One of them is to work through the PTA so that they arrange special tuition for these OVC."

"Through trained community volunteers, ZAMFAM will address vulnerabilities that contribute to children under-performing in school or not progressing to the next level of education by linking children to community-based tutoring opportunities to offer additional support to children who miss school because of illness or other schooling challenges; identify and link families with out-of-school children to bursaries. ZAMFAM will build capacity of community-based and faith-based organizations to integrate school-completion messages and skills into community-level activities such as community savings groups, parenting sessions to help families monitor attendance and performance. ECR will train trainers who will establish Adolescent Clubs for both in- and out-of-school youth, and link clubs to schools, giving out-of-school youth improved opportunity and encouragement to reenter the school system. ZAMFAM will support CBOs to identify strategic, sustainable, and cost-effective linkages for out-of-school youth to vocational training and workplace skills opportunities."

Finding: The percentage of OVC households that had access to money to pay for unexpected household, food-related, or school-related expenses was quite low. Additionally, the socio-economic indicators suggest that OVC households have few fixed assets to draw upon in times of trouble.

Comments from IPs:

"It is the role of the community to identify coping strategies, such as communal gardens and communal granaries, for child-headed households or those headed by aged/disabled caregivers, and establish mechanisms to manage these; but also come up with more 
sustainable ways of promoting resilience. Such children and youths need protection and emotional support from the communities and other well-wishers."

"ECR will strength existing community savings groups and create new ones, and provide mentorship until the groups are self-sustaining. An assessment of household productivity in relation to savings group as an economic strengthening initiative will be conducted to inform future programming."

Finding: Parents, particularly in rural areas, had a rather retrogressive view of the importance of harsh physical punishment in disciplining children.

Comments from IPs:

"The role of traditional leaders such as Chiefs and Headmen as custodians of traditional values and practices should be pronounced. They should be brokers or facilitators to seeking/mobilizing external support for OVC and their families, e.g., coming up with community development plans, which could be 'sold' out to potential supporters."

"ZAMFAM will enhance the delivery of parenting sessions to promote parent-child dialogue and promote child-stimulating activities to support social, emotional, and cognitive development of children. Parenting sessions will build parent/caregiver skills to improve the household emotional environment for the child. Through parenting skills, guardians of OVC will employ positive reinforcement of good behavior of OVC as well as address undesirable behavior through good communication rather than harsh treatment. Through CBO/FBOs, ZAMFAM will provide opportunities for play, fun, and recreation for OVC through the establishment and running of adolescents and kid clubs. The clubs will create a platform for OVC to establish supportive relationships with others." 


\section{REFERENCES}

Andrews, G., D. Skinner, and K. Zuma. 2006. "Epidemiology of health and vulnerability among children orphaned and made vulnerable by HIV/AIDS in sub-Saharan Africa," AIDS Care 18(3): 269-76. doi:10.1080/09540120500471861.

Biemba, Godfrey et al. 2009. "Zambia research situation analysis of orphans and other vulnerable children: Country brief." Lusaka: Boston University Center for Global Health and Development.

Bender, H. L. et al. 2007. "Use of harsh physical discipline and developmental outcomes in adolescence," Dev Psychopathol 19(1): 227 -42. doi:10.1017/S0954579407070125.

Central Statistical Office (CSO). 2012. "2010 Census of population and housing: National descriptive tables." Lusaka: CSO.

Central Statistical Office (CSO), Ministry of Health [Zambia], and ICF International. 2014. Zambia Demographic and Health Survey 2013-2014. Rockville, Maryland USA: Central Statistical Office, Ministry of Health, and ICF international.

Central Statistical Office (CSO) et al. 2009. Zambia Demographic and Health Survey 2007. Calverton, Maryland U.S.A.: CSO and Macro International Inc.

Chatterji, M. et al. 2010. "Evaluating the impact of community-based interventions on schooling outcomes among orphans and vulnerable children in Lusaka, Zambia," Vulnerable Children and Youth Studies 5(2): 130-141.

Fink, G., K. Jack, and F. Masiye. 2016. "The impact of seasonal food and cash loans on smallscale farmers in Zambia." Lusaka: Innovations for Poverty Action.

Government of the Republic of Zambia. 2008. Zambian National Nutrition Surveillance Report. Lusaka: National Food and Nutrition Commission of Zambia.

Government of the Republic of Zambia. 2011. Zambia National Guidelines for HIV Counseling \& Testing of Children. Lusaka: Ministry of Health, Ministry of Community Development, Mother and Child Health.

Government of the Republic of Zambia. 2014. Zambia Consolidated Guideliens for Treatment and Prevention of HIV Infection. Lusaka: Ministry of Health, Ministry of Community Development, Mother and Child Health.

Groves, R. M., Jr. et al. 2009. Survey Methodology, 2nd Edition, Wiley series in survey methodology. Hoboken, NJ, USA: John Wiley \& Sons. 
Howard, B. H. et al. 2006. "Barriers and incentives to orphan care in a time of AIDS and economic crisis: a cross-sectional survey of caregivers in rural Zimbabwe," BMC Public Health 6: 27. doi:10.1186/1471-2458-6-27.

Measure Evaluation. 2014a. Child, Caregiver, and Household Well-being Survey Tools for Orphan and Vulnerable Children Programs: Analysis Guidance. Chapel Hill, NC, USA: Carolina Population Center, University of North Carolina.

Measure Evaluation. 2014b. "Core OVC program impact indicators." Chapel Hill, NC, USA: Carolina Population Center, University of North Carolina.

Measure Evaluation. 2015a. Child, Caregiver and Household Well-being Survey Tools for Orphans and Vulnerable Children Programs: Manual. Chapel Hill, NC, USA: Carolina Population Center, University of North Carolina.

Measure Evaluation. 2015b. Collecting PEPFAR Essential Survey Indicators: A Supplement to the Orphans and Vulnerable Children Survey Tools Guide. Chapel Hill, NC, USA: Carolina Population Center, University of North Carolina.

Minstry of Education Science Vocational Training and Early Education. 2014. "Education for all 2015 national review report: Zambia." Geneva: UNESCO.

Ministry of Health (MOH) [Zambia], Central Statistical Office (CSO), and ORC Macro. 2006. Zambia HIV/AIDS Service Provision Assessment Survey 2005. Calverton, Maryland, USA: MOH, CSO, and ORC Macro.

Mishra, V. and S. B-V. Assche. 2008. Orphans and Vulnerable Children in High HIV Prevalence Countries in Sub-Saharan Africa. Calverton, Maryland, USA: Macro International Inc.

National HIV/AIDS/STI/TB Council (NAC). 2012. "Zambia country report: Monitoring the declaration of commitment on HIV and AIDS and the universal access." Lusaka: NAC.

Richards, K., and S. Bellack. 2016. "Malnutrition in Zambia: Harnessing social protection for the most vulnerable." London: Save the Children.

Tetra Tech ARD. 2013. "Zambia Institutional Reform Program: Quarterly progress report April 1June 30, 2013." Washington, DC: Tetra Tech. 


\section{APPENDICES}




\section{APPENDIX 1 ZAMBIAN GOVERNMENT DEFINITION OF A VULNERABLE CHILD}

Vulnerable child: An individual below the age of 18 and has been, is in, or is likely to be in an adverse condition(s) where he/she is likely to suffer significant physical, emotional, or mental stress that may result in the child's rights not being fulfilled and therefore not enjoying their full development.

\section{LIST OF ADVERSE CONDITIONS}

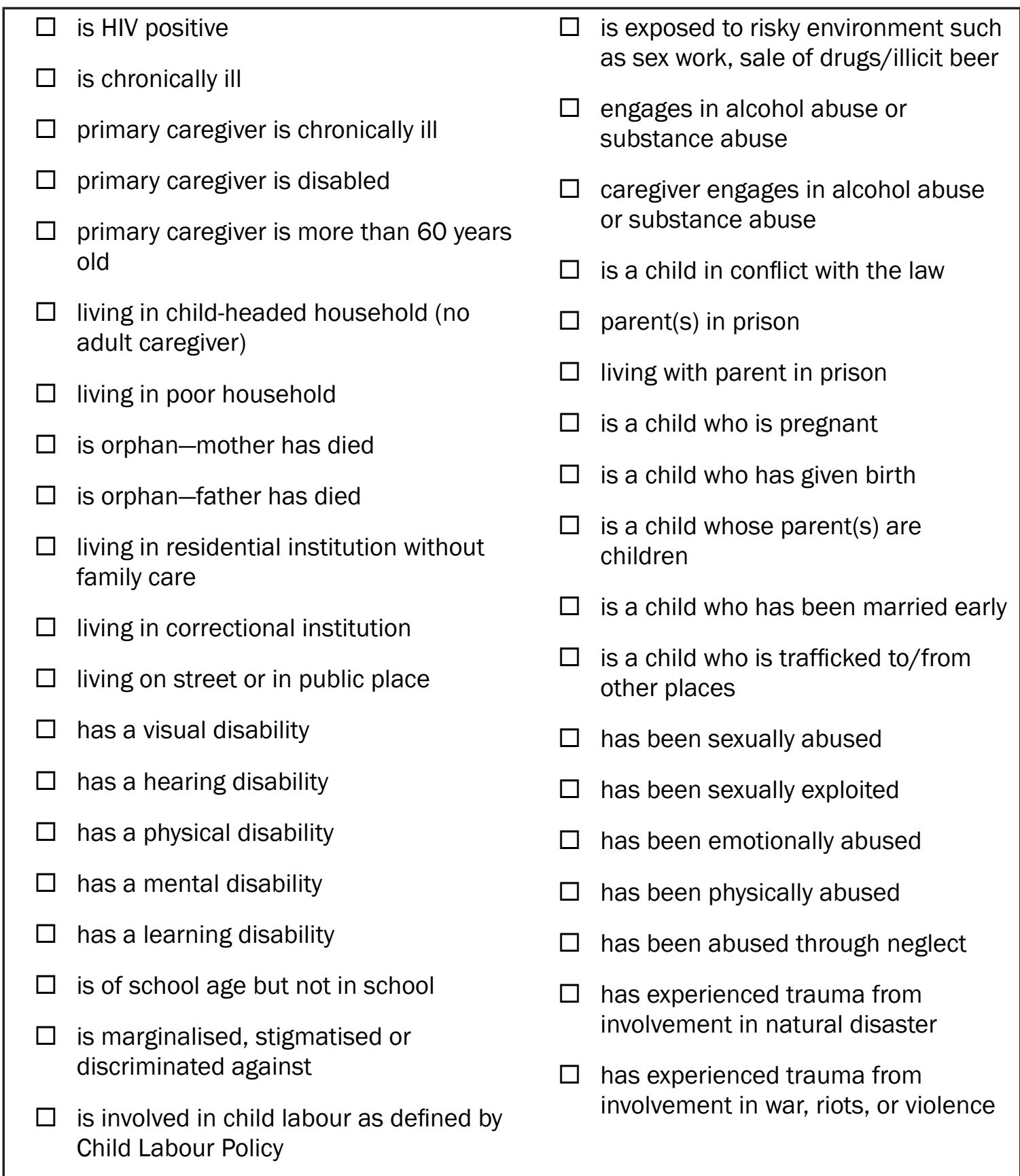




\section{APPENDIX 2 LIST OF PEPFAR PRIORITY DISTRICTS IN FOUR PROVINCES OF STUDY AND ESSENTIAL PEPFAR INDICATORS}

\begin{tabular}{|ll|}
\hline Province & District \\
Central & Kabwe \\
Central & Serenje \\
Central & Mumbwa \\
Central & Mkushi \\
Central & Kapiri-Mposhi \\
Central & Chibombo \\
Copperbelt & Chililamombwe \\
Copperbelt & Chingola \\
Copperbelt & Mufuliara \\
Copperbelt & Kitwe \\
Copperbelt & Ndola \\
Copperbelt & Kalulushi \\
Lusaka & Chirundu \\
Lusaka & Chilanga \\
Lusaka & Chisamba \\
Lusaka & Lusaka \\
Lusaka & Luangwa \\
Lusaka & Kafue \\
Lusaka & Chongwe \\
Lusaka & Shibuyunji \\
Southern & Livingstone \\
Southern & Mazabuka \\
\hline
\end{tabular}




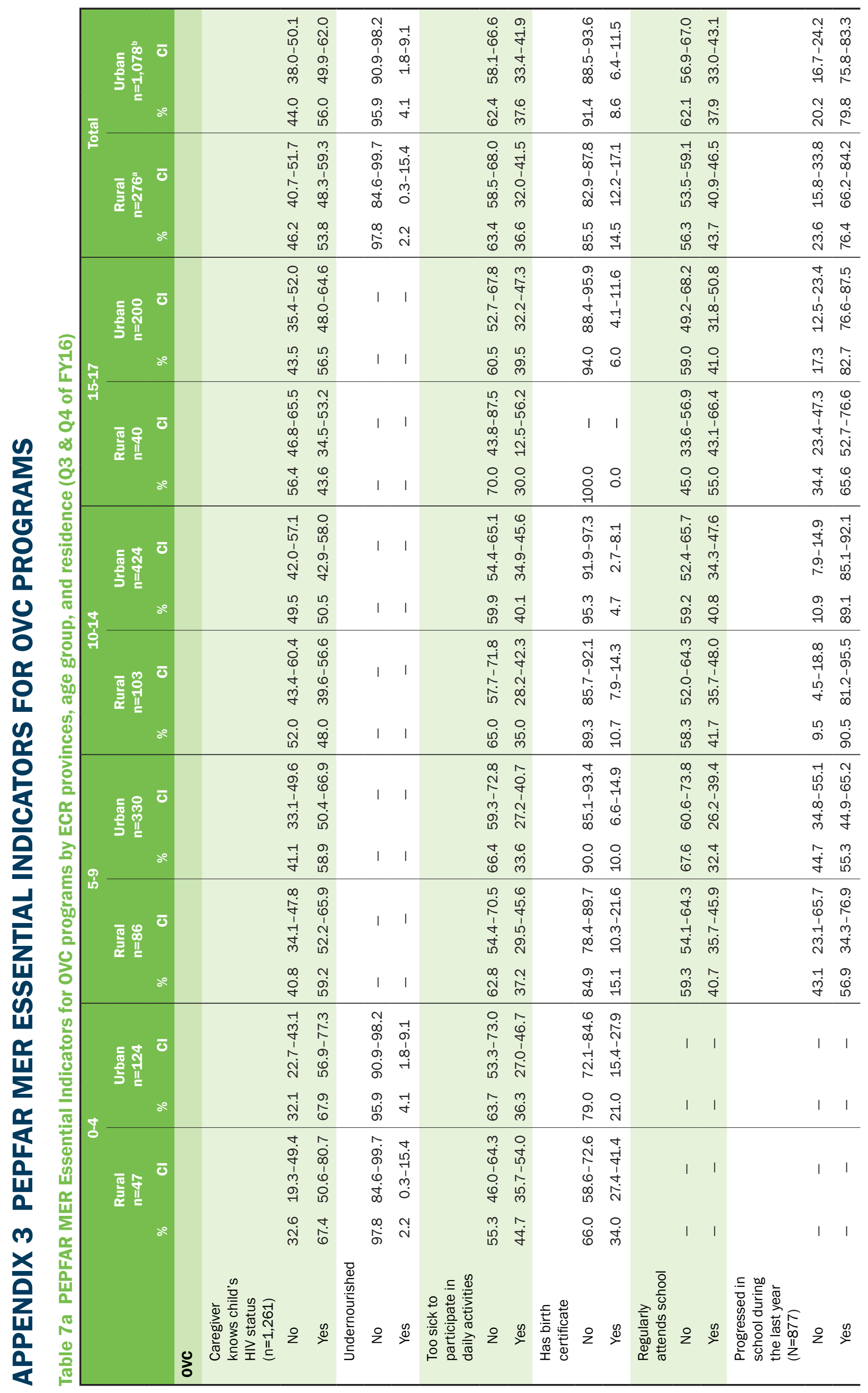




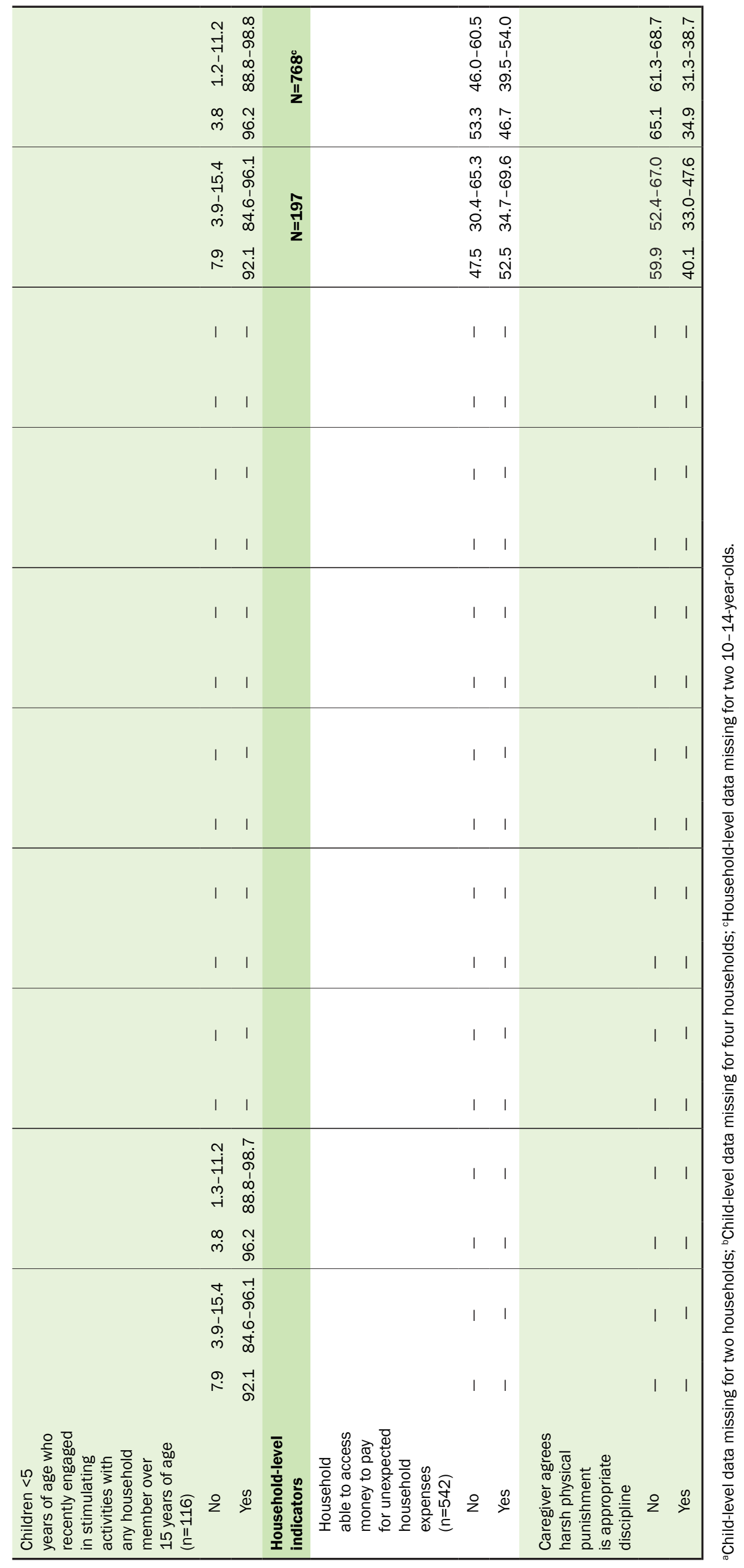




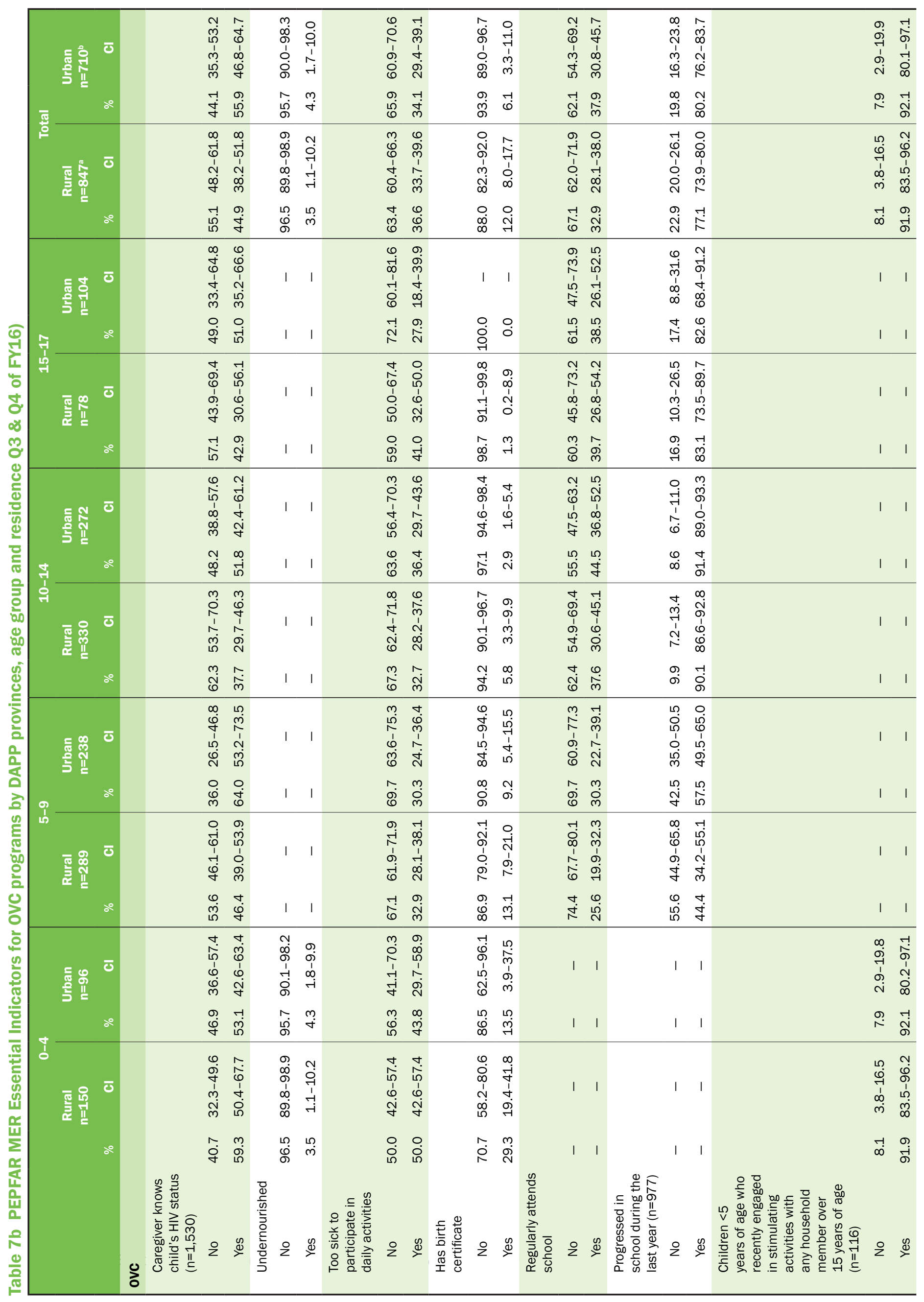





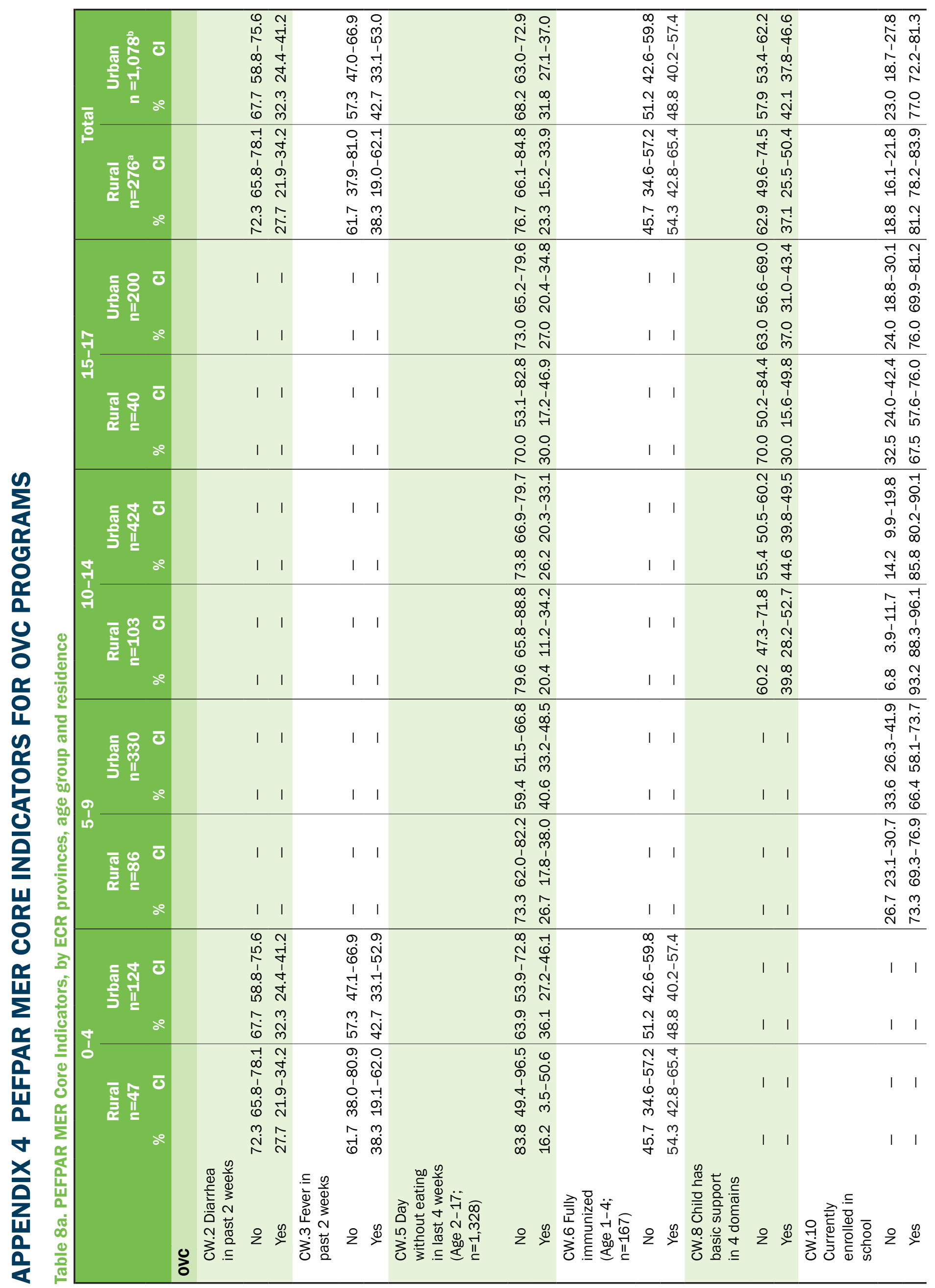




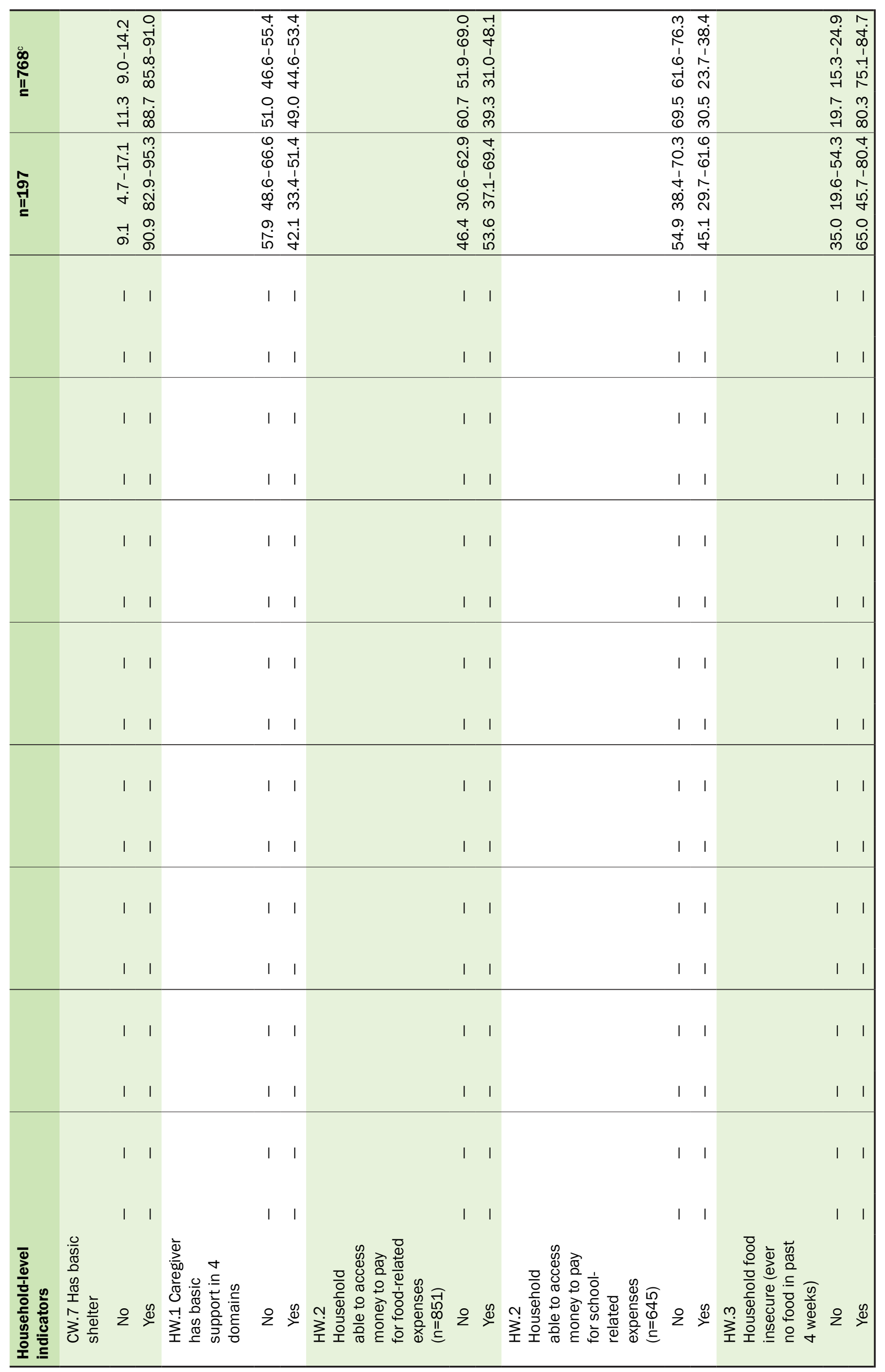




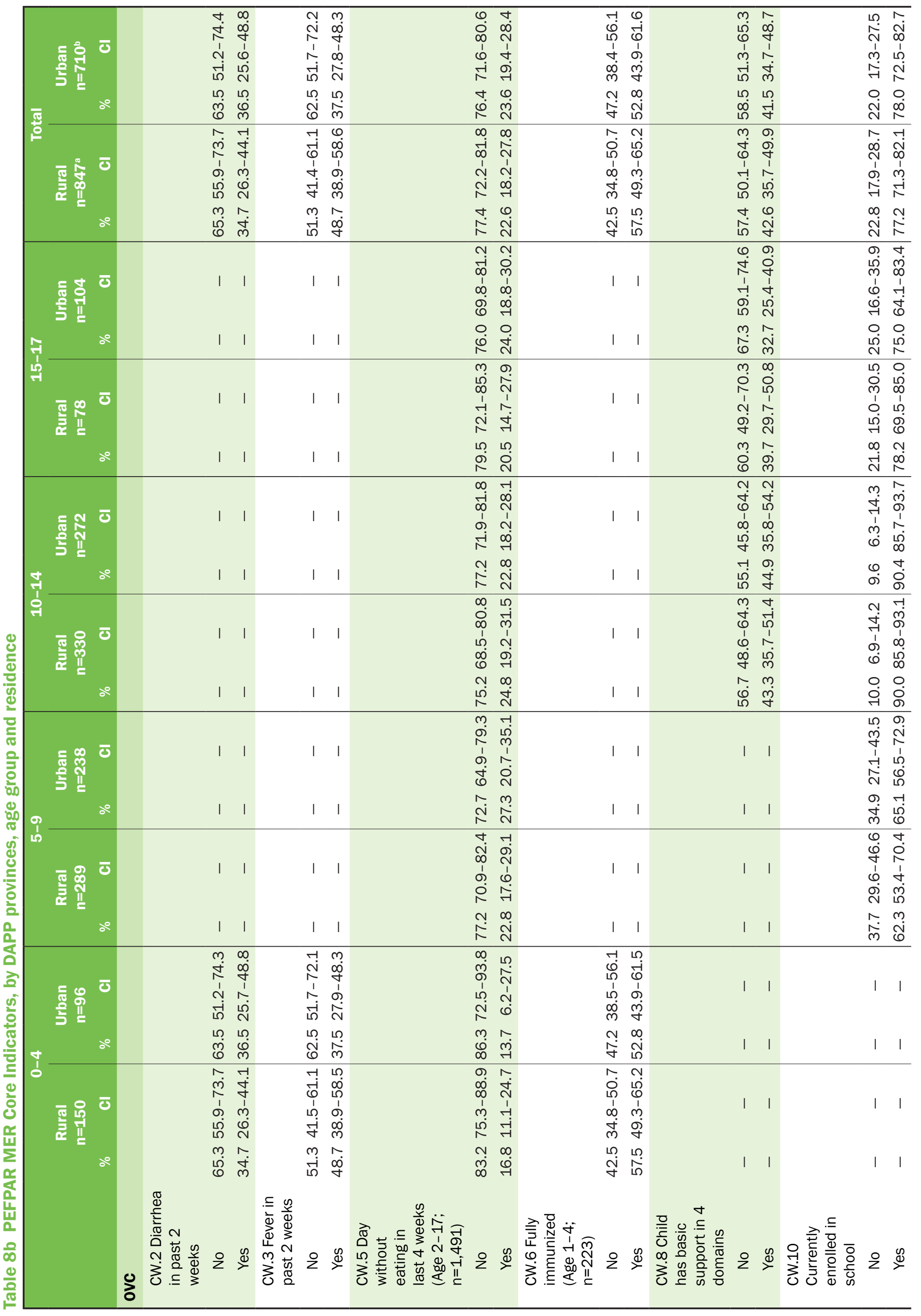




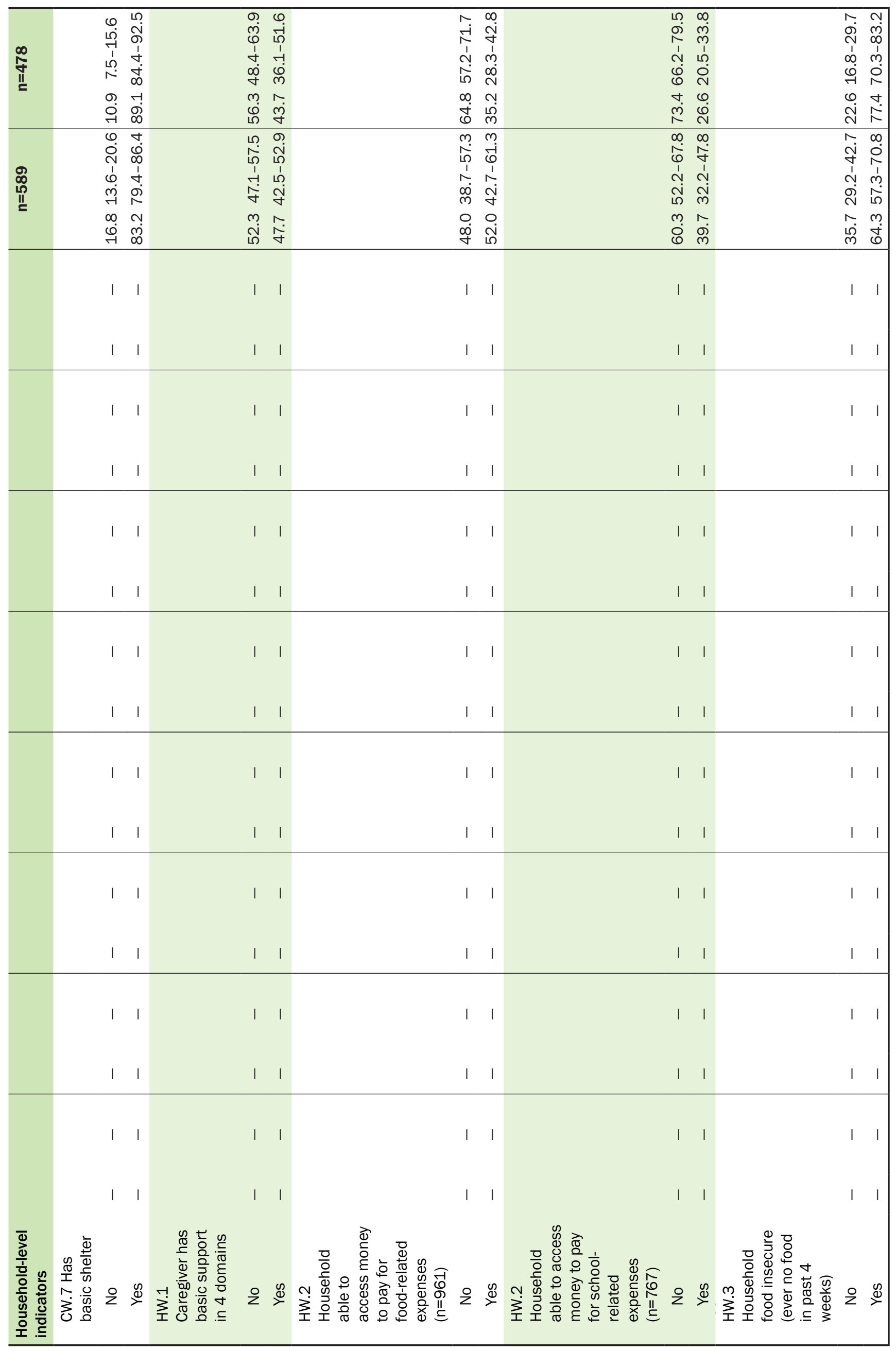




\section{APPENDIX 5 CONFIDENTIALITY AGREEMENT FOR DATA COLLECTORS}

As a member of this research team I understand that I may have access to confidential information about study sites and participants. By signing this statement, I am indicating my understanding of my responsibilities to maintain confidentiality and agree to the following:

- I understand that names and any other identifying information about study sites and participants are completely confidential.

- I agree not to divulge, publish, or otherwise make known to unauthorized persons or to the public any information obtained in the course of this research project that could identify the persons who participated in the study.

- I understand that all information about study sites or participants obtained or accessed by me in the course of my work is confidential. I agree not to divulge or otherwise make known to unauthorized persons any of this information, unless specifically authorized to do so by approved protocol or by the local principal investigator acting in response to applicable law or court order, or public health or clinical need.

- I understand that I am not to read information about study sites or participants, or any other confidential documents, nor ask questions of study participants for my own personal information but only to the extent and for the purpose of performing my assigned duties on this research project.

- I agree to notify the local principal investigator immediately should I become aware of an actual breach of confidentiality or a situation which could potentially result in a breach, whether this be on my part or on the part of another person.

Signature:

Printed name:

Date: 


\section{APPENDIX 6 CONSENT FORM FOR CAREGIVER}

You are invited to take part in a survey. Before you decide whether to participate, you need to understand why the research is being done and what it involves. Please take the time to read or to listen as I read the following information. You may talk to others about the study if you wish. Please ask me if there is anything that is not clear, or if you would like more information. When all of your questions have been answered and you feel that you understand this study, you will be asked if you wish to participate in the study. You will be given a sheet of paper with information about the study in case you have any questions in the future.

\section{Purpose of the Study and Study Requirements}

[What is the study?] We are conducting a survey about child and caregiver well-being so that we can improve the impact of our services and programs. To gather this information, we are interviewing caregivers and older children in some households.

[Why have I been invited to take part?] You have been invited to take part because your household is or has been receiving services from the STEPS-OVC program or the ZAMFAM program or you live in an area where such services will be provided. We have chosen to visit your household from among all the people benefitting or who may receive services from the program through a process of chance.

[What will happen if I take part?] If you agree to take part in the survey, we will first ask you to sign this form. You would then be interviewed about your household, and asked about one child in your care between the ages of 0-9 years (if you have one) who is receiving services from STEPSOVC/ZAMFAM. If you have more than one child of these ages, we will select only one through a process of chance. You will be asked to answer questions about household composition and wealth, general health and nutrition, shelter, schooling, and HIV testing experience. We would also like to measure the width of your child's arm.

The interview with you will take between 30-45 minutes to complete. Your responses will be entered into an electronic device or on paper by the interviewer. Some of the questions are personal and some people may find them difficult to answer. You do not need to answer any questions that you do not want to.

As part of the study, we may also obtain information about your household that the ZAMFAM program organization has on record. This information may include general information about your household members (for example: age, marital status, number of children), information about the health status of household members (for example: nutrition, HIV status, recent deaths) and the services you receive as part of the program.

Risks: The risks to you as a participant in this survey are minimal. You may find one or more questions that we ask to be upsetting or emotionally sensitive. You do not have to respond to any question that makes you uncomfortable. You may end the interview at any time without penalty or loss of any benefits to which you are entitled. 
A risk may be a breach of confidentiality (something you say is accidentally provided to others) but we will take precautions to see that this does not happen. Also, others in the community may see your participation in the survey as an indication that your household is in need of social assistance or that your household has been affected by HIV and AIDS. However, we take steps to minimize this risk. We do not have anything visibly on us that indicates what program we are with. And if anyone asks us what we are doing, we tell people that we are talking to community members who have been randomly selected about how to improve the general quality of life of everyone in this community.

Benefits: There are no direct program benefits to you for participating in the study. You may find an indirect benefit in knowing you have participated in an important study that could help others in the future because your responses will improve our understanding about ways to provide better services to people in communities like yours.

Confidentiality: The information that is collected during the survey will be kept private. No one will be told that you have participated in the study or what your answers are to the questions. The study team will make every effort to protect your privacy and maintain the confidentiality of all the information that you provide. Your name or other identifiers will not be included in reports from this study. The information will be stored in a computer that you need a code to turn on.

At the end of the study, the information provided will be made available to researchers or others who are interested in using it to answer questions about households in Zambia. This means that other people besides the study staff will be able to see the information provided by your household. However, your names and any other personal information that identifies you directly will not be provided to anyone and your responses will be among the responses provided by many hundreds of similar households. As such, no one will be able to know how you personally answered the questions.

Voluntariness: Your participation in this study is completely voluntary. If you decide not to participate, it is OK. You will not lose any existing benefits from STEPS-OVC or ZAMFAM or any other services. If you agree to participate in this survey, you can stop at any time or skip any questions. It will not affect the services you receive from STEPS-OVC or ZAMFAM or any other services.

What will I receive for participating: You will receive a reimbursement of KW 30 for your time today for participation in this study.

What will happen to the results of the research study? The results of the study will be shared with people who are working on ZAMFAM as well as the donor (United States Agency for International Development [USAID]) and the Zambian government so that they can improve the services for people like you. When we tell other people about this research, we will never use names, so no one will ever know what answers you gave me.

Participant Statement: I have read the Informed Consent for this study. I have received an explanation of the planned research, procedures, risks and benefits and privacy of my personal information. I agree to take part in this study. I understand that my participation in this study is voluntary. (Please circle all that apply) 


\begin{tabular}{|l|c|c|c|}
\hline & \multicolumn{2}{|c|}{ Circle } \\
\hline Do you have any questions? If yes, note questions below & Yes & No \\
\hline I agree to respond to the caregiver survey & Yes & No \\
\hline If applicable: & & \\
I agree to respond to questions regarding one child (0-9 years) & Yes & No & N/A \\
I agree to have you measure the width of my 0-5 year old child's arm, & Yes & No & N/A \\
\hline
\end{tabular}

Name of caregiver (print):

$\overline{\text { Date }} \overline{\text { Signature of parent/guardian }} \overline{*(\text { mark }) / \text { Thumbprint }}$

*In case the respondent is not able to sign this form, this attests that the consent form has been read and explained accurately by a member of the research staff, and that the respondent has marked the spaced with an ' $\mathrm{X}$ ' or thumbprint.

Witness (if volunteer is illiterate):

I sign here as a witness to the consent process. I have participated in the discussion and witnessed the volunteer's consent to study participation. All of the writing required of the participant on this informed consent form (initials, indication of left/right thumb print, date, time, ec) was written by me on behalf of the volunteer:

Name of witness (print):

$\overline{\text { Date }} \quad \overline{\text { Signature: Witness }}$

\section{Interviewer's statement}

I, the undersigned, have defined and explained to the participant in a language that she/he understands, the procedures to be followed, the risks and benefits involved, and the obligations of the interviewer.

Interviewer name (print): 


\section{APPENDIX 7 INFORMATION SHEET PROVIDED TO PARTICIPANT}

Project Title: A benchmark assessment of care and support services delivered to orphaned and vulnerable children (OVC) through the Zambia Family (ZAMFAM) project

Who has reviewed the study for ethical issues? This study has been reviewed by the Population Council and the local ethics board here in Zambia named ERES.

What if I need more information? If you have a concern about any aspect of the study, you should ask to speak to the researchers who will do their best to answer your questions. You may call the study's Principal Investigator, Dr. Mike Mbizvo from the Population Council.

What if there is a problem? Any complaint about the way you have been treated during the study or any possible harm you might suffer will be addressed. Please contact the local ethics board ERES.

Michael Mbizvo, Ph. D

Population Council

Plot 3670, No 4. Mwaleshi Road

Olympia Park, Zambia

Office tel: 0211262665

Direct tel: 0211262666

\section{ERES Converge}

33 Joseph Mwilwa Road

Rhodes Park, Lusaka

Tel: +260955 155 633/4

E-mail: eresconverage@yahoo.co.uk 


\section{APPENDIX 8 INFORMATION AND PARENT/GUARDIAN PERMISSION FORM FOR CHILD PARTICIPATION}

We would like to speak to one child aged 10-17 in this household. Before you decide whether to allow your child to participate, you need to understand why the research is being done and what it would involve. Please take the time to read or to listen as I read the following information.

You may talk to others about the study if you wish. Please ask me if there is anything that is not clear, or if you would like more information. When all of your questions have been answered and you feel that you understand this study, you will be asked for your consent for your child to participate in the study. You will be given a sheet of paper with information about the study in case you have any questions in the future. We will also directly ask your child whether he/she wants to participate in this study.

\section{Purpose of the Study and Study Requirements}

[What is the study?] We are conducting a survey about child and caregiver well-being so that we can improve the impact of our services and programs. To gather this information, we are interviewing caregivers and older children in some households.

[Why has my child been invited to take part?] Your child has been invited to take part because he/she has been receiving services from the STEPS-OVC program or the ZAMFAM program or you live in an area where such services will be provided. He/she was selected from among the people receiving services or who may receive services from the program through a process of chance.

[What will happen if my child takes part?] If you agree to let your child take part in the study, we will first ask you to sign this form. If you consent, we will also tell the child about study and what his/her participation in it will involve and ask for his/her agreement to participate.

Your child will be asked questions about their general health and nutrition, shelter, schooling, and HIV testing experience. For those aged 15 years and older, we also want to learn about HIV knowledge, sexual behaviors, and alcohol consumption. We would also measure the width of your child's arm. We will speak to the child alone, but within your sight. You will not be told the responses to their questions, but he or she can request to have you present during the interview at any time.

The interview with your child will take between 30-45 minutes to complete. The responses will be entered into an electronic device or on paper by the interviewer. Some of the questions are personal and some people may find them difficult to answer. Your child does not need to answer any questions that he/she does not want to.

As part of the study, we may also obtain information about your household that the ZAMFAM program organization has on record. This information may include general information about your household members (for example: age, marital status, number of children), information about the health status of household members (for example: nutrition, HIV status, recent deaths) and the services you receive as part of the program. 
Risks: The risks to your child as a participant are minimal. Some of the questions might be a bit personal, upsetting, and some children may find them difficult to answer. But he/she does not have to answer any questions that he/she is not comfortable with, and may end the survey at any time without penalty or loss of any benefits to which he/she is entitled.

A risk may be a breach of confidentiality (something he/she says is accidentally provided to others) but we will take precautions to see that this does not happen. Also, others in the community may see participation in the survey as an indication that your household is in need of social assistance or that your household has been affected by HIV and AIDS. However, we take steps to minimize this risk. We do not have anything visibly on us that indicates what program we are with. And if anyone asks us what we are doing, we tell people that we are talking to community members who have been randomly selected about how to improve the general quality of life of everyone in this community.

Benefits: There are no direct program benefits to you or your child for participating in the study. You may find an indirect benefit in knowing your child has participated in an important study that could help others in the future because as his or her responses will improve our understanding about ways to provide better services for children and young people.

Confidentiality: The information that is collected during the interview will be kept private. No one will be told that your child has participated in the study or what his/her answers are to the questions. The study team will make every effort to protect your child's privacy and maintain the confidentiality of all the information that he/she provides. Your child's name or other identifiers will not be included in reports from this study.

There is one exception. If your child tells us about experiences where someone is presently hurting them or if they think they might need some sort of counseling, we will inform a ZamFam program staff member to make sure s/he are helped.

At the end of the study, the information provided will be made available to researchers or others who are interested in using it to answer questions about households in Zambia. This means that others people besides the study staff will be able to see the information provided by your household. However, your names and any other personal information that identifies you directly will not be provided to anyone and your responses will be among the responses provided by many hundreds of similar households. As such, no one will be able to know how you personally answered the questions.

Voluntariness: Your child's participation in this study is completely voluntary. If your child decides not to participate, it is OK. He/she will not lose any existing benefits from STEPS-OVC or ZAMFAM or any other services. You may also end his/her participation at any time. It will not affect the services you receive from STEPS-OVC or ZAMFAM or any other services.

What will my child receive for participating? You will receive a reimbursement of KW 30 for your time today for participation in this study.

What will happen to the results of the research study? The results of the study will be shared with people who are working on ZAMFAM as well as the donor (United States Agency for 
International Development [USAID]) and the Zambian government so that they can improve the services for people like you. When we tell other people about this research, we will never use names, so no one will ever know what answers the child gave me.

Participant Statement: I have read the Informed Consent for this study as it pertains to the child in my care participant. I have received an explanation of the planned research, procedures, risks, and benefits and privacy of my and their personal information. I agree that the child in my care can take part in this study. I understand that his/her participation in this study is voluntary. (Please circle all that apply)

\begin{tabular}{|l|c|c|c|}
\hline & \multicolumn{2}{|c|}{ Circle } \\
\hline Do you have any questions? If yes, note questions below & Yes & No \\
\hline I agree to allow the child in my care to respond to the survey. & Yes & No & \\
\hline $\begin{array}{l}\text { If applicable: } \\
\text { I agree to have you measure the width of the arm of the child in may care. }\end{array}$ & Yes & No & N/A \\
\hline
\end{tabular}

Name of caregiver (print):

Date

$$
\text { Signature of parent/guardian }
$$

*(mark)/Thumbprint

*In case the respondent is not able to sign this form, this attests that the consent form has been read and explained accurately by a member of the research staff, and that the respondent has marked the spaced with an ' $X$ ' or a thumbprint.

Witness (if volunteer is illiterate):

I sign here as a witness to the consent process. I have participated in the discussion and witnessed the volunteer's consent to study participation. All of the writing required of the participant on this informed consent form (initials, indication of left/right thumb print, date, time, ec) was written by me on behalf of the volunteer:

Name of witness (print):

Date

Signature: Witness

\section{Interviewer's statement}

I, the undersigned, have defined and explained to the participant in a language that she/he understands, the procedures to be followed, the risks and benefits involved, and the obligations of the interviewer.

Interviewer name (print): 


\section{APPENDIX 9 INFORMATION SHEET PROVIDED TO PARTICIPANT}

Project Title: A benchmark assessment of care and support services delivered to orphaned and vulnerable children (OVC) through the Zambia Family (ZAMFAM) project

Who has reviewed the study for ethical issues? This study has been reviewed by the Population Council and the the local ethics board here in Zambia named ERES.

What if I need more information? If you have a concern about any aspect of the study, you should ask to speak to the researchers who will do their best to answer your questions. You may call the study's Principal Investigator, Dr. Mike Mbizvo from the Population Council.

What if there is a problem? Any complaint about the way you have been treated during the study or any possible harm you might suffer will be addressed. Please contact the local ethics board ERES.

Michael Mbizvo, Ph. D

Population Council

Plot 3670, No 4. Mwaleshi Road

Olympia Park, Zambia

Office tel: 0211262665

Direct tel: 0211262666

\section{ERES Converge}

33 Joseph Mwilwa Road

Rhodes Park, Lusaka

Tel: +260 955155 633/4

E-mail: eresconverage@yahoo.co.uk 


\section{APPENDIX 10 CHILD ASSENT (10-17 YEAR OLDS)}

You are being asked to take part in a research study. A research study seeks to understand the issues that children such as yourself face in Zambia. Before you decide whether to answer some questions as part of the study, you need to understand why the study is being done and what it would involve. Please take the time to listen (or read) as I read the following information. You may talk to others about the study if you wish. Please ask me if there is anything that is not clear, or if you would like more information. When all of your questions have been answered and you feel that you understand this study, you will be asked if you are willing to answer the questions. You will be given an information sheet with information about the study in case you have an questions in the future.

Your caregiver has already given permission. However, you do not have to say yes. We have talked to your caregiver and he/she agrees that you do not have to say yes.

\section{Purpose of the Study and Study Requirements}

[What is the study?] We are asking questions to children and their caregiver about their wellbeing so that we can improve the services and programs that you or families like you may receive.

[Why have I been invited to take part?] You have been being asked to take part because your family or household has been receiving services from the STEPS-OVC program or the ZAMFAM program or you live in an area where such services will be provided. You were selected from among the people receiving services or who may receive services from the program through a process of chance.

What will happen if I take part? If you agree answer the questions, we will ask you to sign this form to show you agree. You will be asked questions about your general health and nutrition, shelter, schooling, and HIV testing experience. [If over 15 years old only] We also want to learn about HIV knowledge, sexual behaviors, and alcohol consumption. We would also like to measure the width of your arm.

We would like to speak to you alone, but within sight of your caregiver. We are not going to give any of your answers to your caregiver or anyone else in your household. You may ask, however, to have your caregiver with you during our talk if you wish. It will take between 30-45 minutes to complete the questions we want to ask you. Your answers will be entered into a computer or on paper by the interviewer. Some of the questions are personal and some people may find them difficult to answer. You do not need to answer any questions that you do not want to.

We may also obtain information about your household that the ZAMFAM program organization has on record. This may include general information about your household members (for example: age, marital status, number of children), information about the health status of household members (for example: nutrition, HIV status, recent deaths) and the services you receive as part of the program. 
Risks: The risks to you as a participant are minimal. Some of the questions might be a bit personal, upsetting, and some children may find them difficult to answer. But you do not have to answer any questions that you do not want to and you may end the survey at any time without penalty or loss of any benefits from the ZAMFAM program or other programs.

A risk may be that something you say is accidentally told to others, but we will be very careful to make sure that this does not happen. Also, others in the community may see that because you are answering our questions, that your household is in need of help or that your household has been affected by HIV and AIDS. However, we take steps to make sure this does not happen. We do not have anything that someone can see on us that shows what program we are with. And if anyone asks us what we are doing, we tell people that we are talking to community members who have been selected by chance about how to make the lives of people in the community better.

Benefits: There are no direct program benefits to you for answering our questions. You may find a benefit in knowing you have provided information for an important study that could help others in the future because your responses will improve our understanding about ways to provide better services for children and young people.

Confidentiality: Everything you say today is confidential. That means that no one will know whom this information came from, not even the people from the program who provide services. The study team will make every effort to protect your privacy and protect all the information that you provide. Your name or other information that can identify who you are will not be included in reports from this study.

There is one case where we cannot maintain such confidentiality. If you tell us about experiences where someone is presently hurting you or if you think you might need some sort of counseling, we will inform a ZAMFAM program staff member to make sure you are helped.

At the end of the study, the answers you give will be made available to researchers or others who are interested in using it to answer questions about households in Zambia. This means that others people besides the study staff will be able to see the information provided by your household. However, your names, where you live and any other personal information that identifies you directly will not be provided to anyone and your responses will be among the responses provided by many hundreds of similar households. As such, no one will be able to know how you yourself answered the questions.

Voluntariness: Answering our questions is completely voluntary. If you decide not to answer our questions, it is OK. Your caregiver may also stop us asking questions at any time. You will not lose any benefits from STEPS-OVC or ZAMFAM or any other services.

What will I receive for participating? You will receive KW 30 for your time today spent answering our questions.

What will happen to the results of the research study? The results of the study will be shared with people who are working on ZAMFAM as well as the donor (United States Agency for International Development [USAID]) and the Zambian government so that they can improve the services for people like you. When we tell other people about this research, we will never use names, so no one will ever know what answers you gave me. 
Participant Statement: I have read the Informed Consent for this study. I have received information on why I am being asked these questions, what I am being asked, and the risks and benefits of my answering the questions and the protection of the information I provide. I agree to take part in this study. I understand that my participation in this study is voluntary. (Please circle all that apply)

\begin{tabular}{|c|c|c|c|}
\hline & \multicolumn{3}{|c|}{ Circle } \\
\hline Do you have any questions? If yes, note questions below & Yes & No & \\
\hline I agree to respond to the survey. & Yes & No & \\
\hline If applicable: & & & \\
\hline I agree to have you measure the width of my arm. & Yes & No & N/A \\
\hline
\end{tabular}

Name of child (print):

$\overline{\text { Date }} \overline{\text { Signature of child }} *$ (mark)/Thumbprint

* In case the respondent is not able to sign this form, this attests that the consent form has been read and explained accurately by a member of the research staff, and that the respondent has marked the spaced with an ' $X$ ' or thumbprint.

Witness (if volunteer is illiterate):

I sign here as a witness to the consent process. I have participated in the discussion and witnessed the volunteer's consent to study participation. All of the writing required of the participant on this informed consent form (initials, indication of left/right thumb print, date, time, etc...) was written by me on behalf of the volunteer:

Name of witness (print):

Date

Signature: Witness

\section{Interviewer's statement}

I, the undersigned, have defined and explained to the participant in a language that she/he understands, the procedures to be followed, the risks and benefits involved, and the obligations of the interviewer.

Interviewer name (print): 


\section{APPENDIX 11 INFORMATION SHEET PROVIDED TO PARTICIPANT}

Project Title: A benchmark assessment of care and support services delivered to orphaned and vulnerable children (OVC) through the Zambia Family (ZAMFAM) project

Who has reviewed the study for ethical issues? This study has been reviewed by the Population Council and the the local ethics board here in Zambia named ERES.

What if I need more information? If you have a concern about any aspect of the study, you should ask to speak to the researchers who will do their best to answer your questions. You may call the study's Principal Investigator, Dr. Mike Mbizvo from the Population Council.

What if there is a problem? Any complaint about the way you have been treated during the study or any possible harm you might suffer will be addressed. Please contact the local ethics board ERES.

Michael Mbizvo, PhD

Population Council

Plot 3670, No 4. Mwaleshi Road

Olympia Park, Zambia

Office tel: 0211262665

Direct tel: 0211262666

\section{ERES Converge}

33 Joseph Mwilwa Road

Rhodes Park, Lusaka

Tel: +260 955155 633/4

E-mail: eresconverage@yahoo.co.uk 


\title{
APPENDIX 12 ELIGIBILITY CHECKLIST
}

\author{
Ward name \\ Ward code \\ House ID number \\ Research assistant ID \\ Research assistant name
}

\begin{tabular}{|c|c|c|}
\hline \multicolumn{2}{|r|}{$\begin{array}{l}\text { Ask the caregiver all of the following questions so that we can collect this } \\
\text { information on each of the eligibility criteria. Then indicate at the bottom of the } \\
\text { page whether the household is eligible or ineligible. }\end{array}$} & \multirow{2}{*}{$\begin{array}{l}\begin{array}{l}\text { Circle number next to } \\
\text { response }\end{array} \\
\begin{array}{l}0=\text { No } \rightarrow \text { INELIGIBLE } \\
1=\text { Yes }\end{array}\end{array}$} \\
\hline 1 & Is the household a current beneficiary of ZAMFAM services & \\
\hline 2 & Is there an OVC in the age group $0-17$ years being cared for in this household & $\begin{array}{l}0=\mathrm{No} \rightarrow \text { INELIGIBLE } \\
1=\text { Yes }\end{array}$ \\
\hline 3 & Do you live in selected ward within the ZAMFAM project & $\begin{array}{l}0=\text { No } \rightarrow \text { INELIGIBLE } \\
1=\text { Yes }\end{array}$ \\
\hline 4 & Are you 18 years of age or older & $\begin{array}{l}0=\text { No } \rightarrow \text { INELIGIBLE } \\
1=\text { Yes }\end{array}$ \\
\hline 5 & Have you provided informed consent to participate & $\begin{array}{l}0=\mathrm{No} \rightarrow \text { INELIGIBLE } \\
1=\text { Yes }\end{array}$ \\
\hline \multicolumn{3}{|c|}{ Ovc 0-9 years old: } \\
\hline 6 & Is the OVC a beneficiary of ZAMFAM services & $\begin{array}{l}0=\text { No } \rightarrow \text { INELIGIBLE } \\
1=\text { Yes }\end{array}$ \\
\hline 7 & Is the OVC 0 to 9 years of age & $\begin{array}{l}0=\mathrm{No} \rightarrow \text { INELIGIBLE } \\
1=\text { Yes }\end{array}$ \\
\hline 8 & $\begin{array}{l}\text { Does the OVC live in the same household as the primary caregiver who is } \\
\text { interviewed for the benchmark survey }\end{array}$ & $\begin{array}{l}0=\mathrm{No} \rightarrow \text { INELIGIBLE } \\
1=\text { Yes }\end{array}$ \\
\hline 9 & $\begin{array}{l}\text { Has the OVC been randomly selected, if there are more than one OVC of the age } \\
\text { group in the household }\end{array}$ & $\begin{array}{l}0=\text { No } \rightarrow \text { INELIGIBLE } \\
1=\text { Yes }\end{array}$ \\
\hline \multicolumn{3}{|c|}{ OVC 10-17 years old: } \\
\hline 10 & Is the OVC a current beneficiary of ZAMFAM services & $\begin{array}{l}0=\text { No } \rightarrow \text { INELIGIBLE } \\
1=\text { Yes }\end{array}$ \\
\hline 11 & Is the OVC 10 to 17 years of age & $\begin{array}{l}0=\text { No } \rightarrow \text { INELIGIBLE } \\
1=\text { Yes }\end{array}$ \\
\hline 12 & $\begin{array}{l}\text { Does the OVC live in the same household as the primary caregiver who is } \\
\text { interviewed for the benchmark survey }\end{array}$ & $\begin{array}{l}0=\mathrm{No} \rightarrow \text { INELIGIBLE } \\
1=\text { Yes }\end{array}$ \\
\hline 13 & Has the OVC given informed assent along with caregiver's consent to participate & $\begin{array}{l}0=\text { No } \rightarrow \text { INELIGIBLE } \\
1=\text { Yes }\end{array}$ \\
\hline 14 & $\begin{array}{l}\text { Has the OVC been randomly selected, if there are more than one OVC of the age } \\
\text { group in the household }\end{array}$ & $\begin{array}{l}0=\mathrm{No} \rightarrow \text { INELIGIBLE } \\
1=\text { Yes }\end{array}$ \\
\hline
\end{tabular}

\section{HOUSEHOLD IS ELIGIBLE}

Data entered by:

\section{HOUSEHOLD IS INELIGIBLE}

Date $(\mathrm{dd} / \mathrm{mm} / \mathrm{yyyy})$ : 


\section{APPENDIX 13 HOUSEHOLD AND CAREGIVER QUESTIONNAIRE}

Adapted from: MEASURE Evaluation OVC Caregiver Questionnaire, Version 1.4

IDENTIFICATION DATA

\begin{tabular}{|l|l|l|l|}
\hline 001 & QUESTIONNAIRE IDENTIFICATION NUMBER & \\
\hline 002 & ZAMFAM DATABASE NUMBER & \\
\hline 003 & PROVINCE OR STATE & \\
\hline 004 & DISTRICT OR LOCAL GOVERNMENT AREA & \\
\hline 005 & CONSTITUENCY & \\
\hline 006 & WARD & $\begin{array}{l}\mid \\
\text { Rural }\end{array}$ \\
\hline 007 & $\begin{array}{l}\text { TYPE OF LOCATION } \\
\text { CirCle }\end{array}$ & & \\
\hline 008 & TOWN/VILLAGE & & \\
\hline 009 & NEIGHBOURHOOD & \\
\hline
\end{tabular}

INTERVIEW LOG

\begin{tabular}{|l|l|l|l|}
\hline & VISIT 1 & VISIT 2 & VISITI 3 \\
\hline DATE (day/month/year) & & & \\
\hline INTERVIEWER COMMENTS & & & \\
\hline
\end{tabular}

Interview comment codes: Interview completed 1; Appointment made for later today 2; Appointment made for another day 3; Refused to continue and no appointment made 4; Other (Specify) 5

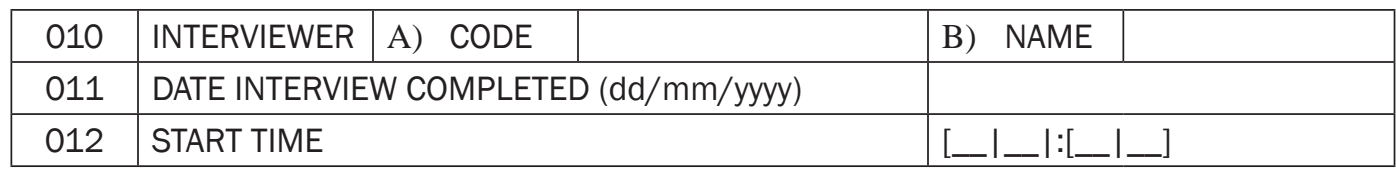

CHECKED BY TEAM LEADER:

Signature Date (dd/mm/yy)

Comments 


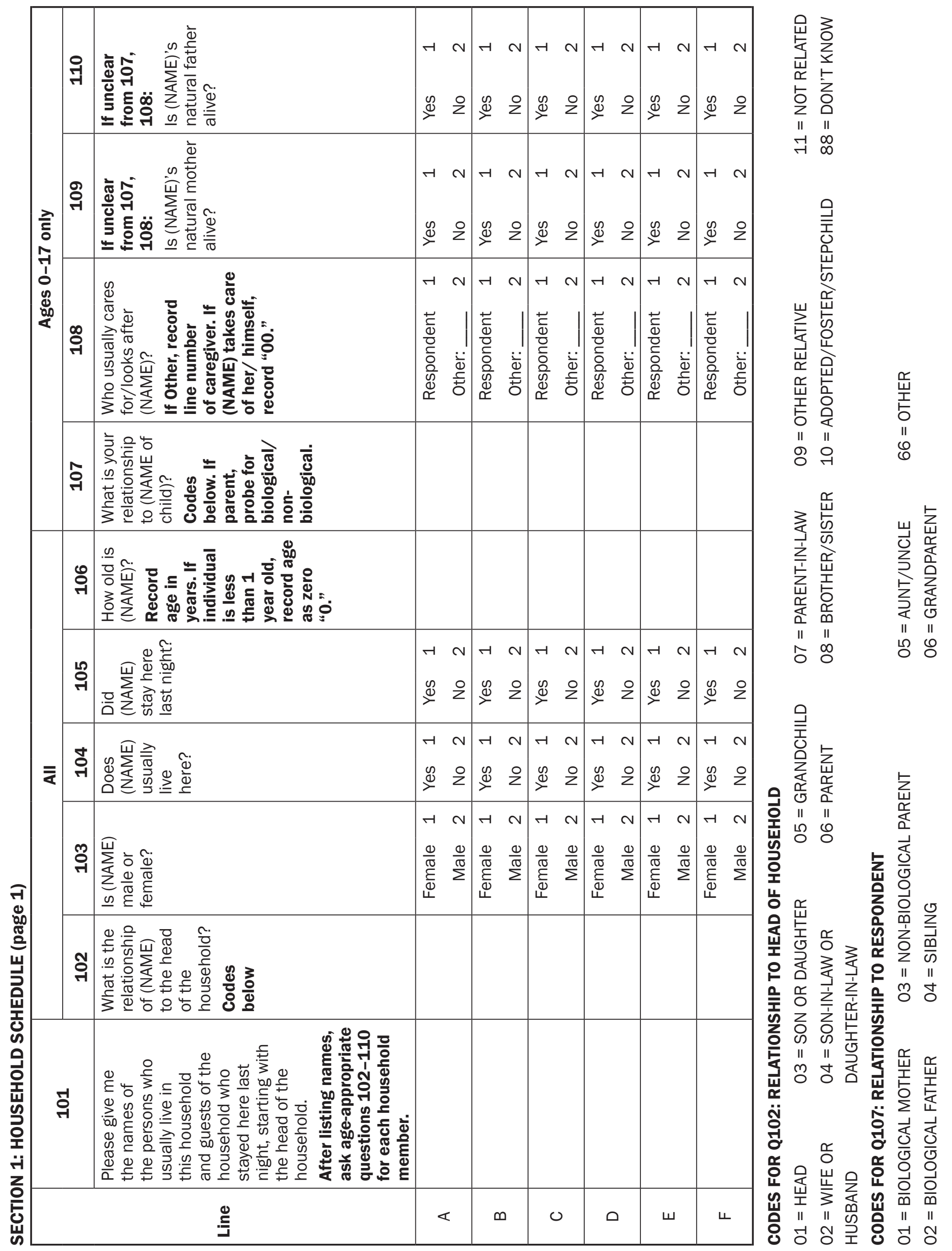




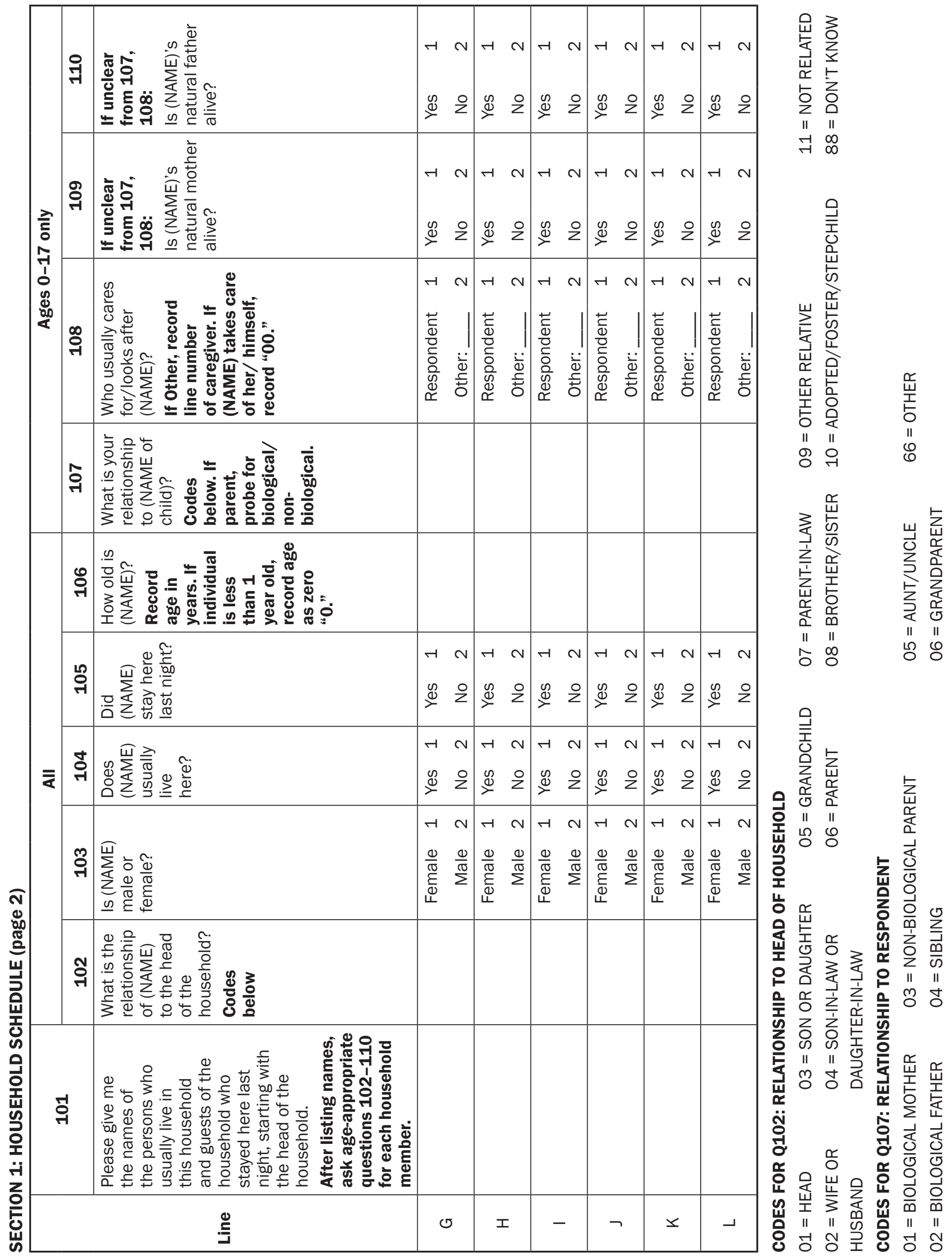

70 - Benchmark assessment of OVC in areas of the ZAMFAM Project 


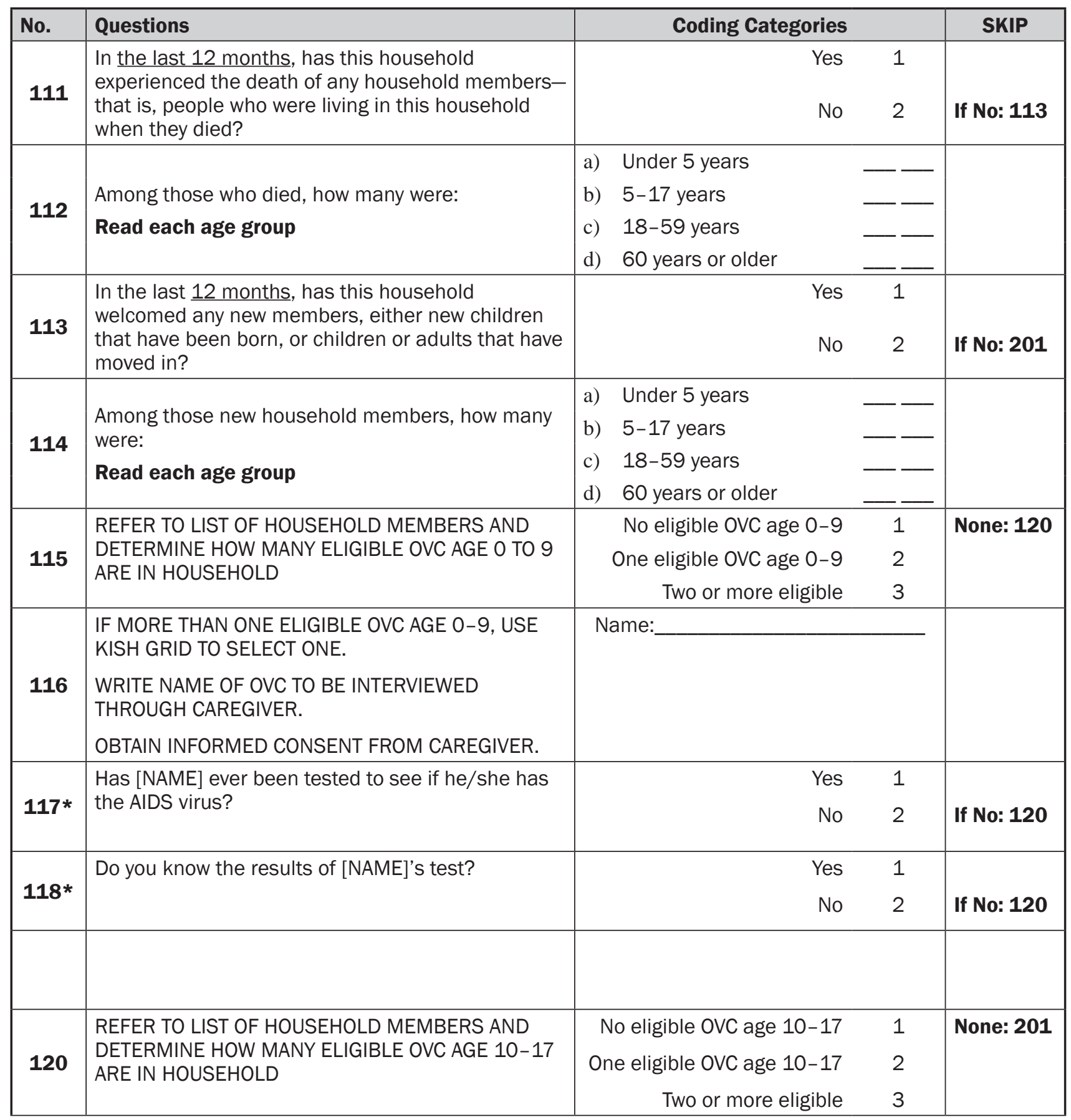




\begin{tabular}{|c|c|c|c|c|}
\hline No. & Questions & Coding Categories & & SKIP \\
\hline 121 & $\begin{array}{l}\text { IF MORE THAN ONE ELIGIBLE OVC AGE 10-17, USE } \\
\text { KISH GRID TO SELECT ONE. } \\
\text { WRITE NAME OF OVC TO BE INTERVIEWED } \\
\text { THROUGH CAREGIVER. } \\
\text { OBTAIN INFORMED CONSENT FROM CAREGIVER. }\end{array}$ & Name: & & \\
\hline $122 *$ & $\begin{array}{l}\text { Has [NAME] ever been tested to see if he/she has } \\
\text { the AIDS virus? }\end{array}$ & $\begin{array}{l}\text { Yes } \\
\text { No }\end{array}$ & 2 & If No: 201 \\
\hline $123 *$ & Do you know the results of [NAME]'s test? & $\begin{array}{l}\text { Yes } \\
\text { No }\end{array}$ & 2 & If No: 201 \\
\hline 124 & $\begin{array}{l}\text { Would you tell me the result of [NAME]'s test? We } \\
\text { will keep the result completely confidential. }\end{array}$ & $\begin{array}{r}\text { Positive } \\
\text { Negative } \\
\text { Indeterminate } \\
\text { No answer }\end{array}$ & 4 & \\
\hline 125 & $\begin{array}{l}\text { CHECK } 115 \text { AND } 120 \text { ARE BOTH “NO,” CONFIRM } \\
\text { THAT NO ELIGIBLE OVC ARE IN HOUSEHOLD. } \\
\text { IF THERE ARE NO ELIGIBLE OVC, THANK } \\
\text { CAREGIVER AND DO NOT PROCEED TO SURVEY } \\
\text { INTERVIEW. }\end{array}$ & $\begin{array}{r}\text { At least one eligible OVC in } \\
\text { household } \\
\text { No eligible OVC in } \\
\text { household }\end{array}$ & 2 & If 1:201 \\
\hline 126 & $\begin{array}{l}\text { INQUIRE WITH CAREGIVER FOR REASON WHY NO } \\
\text { OVC ARE PRESENT IN THE HOUSEHOLD, WHILE } \\
\text { ZAMFAM DATABASE RECORDS INDICATED THAT } \\
\text { THERE WAS. }\end{array}$ & $\begin{array}{r}\text { OVC grew up/older than } 17 \\
\text { OVC died } \\
\text { Never was any OVC in } \\
\text { household } \\
\text { Other (specify): } \\
\text { Don't know }\end{array}$ & $\begin{array}{l}1 \\
2 \\
3\end{array}$ & All: END \\
\hline
\end{tabular}

-END OF SECTION-

SECTION 2: BACKGROUND INFORMATION ON CAREGIVER \& HOUSEHOLD 
I'm going to ask you some basic questions about yourself and your household.

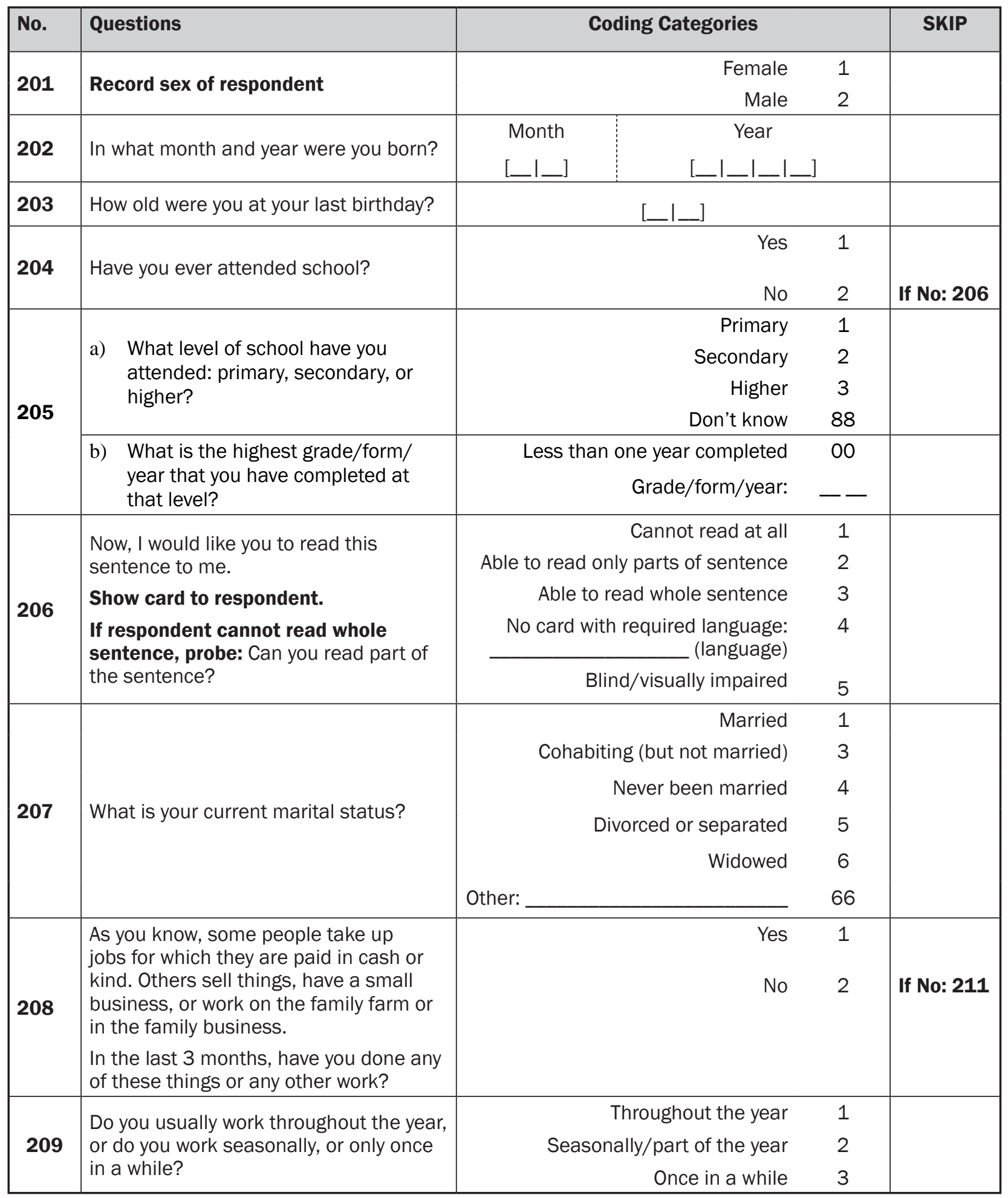




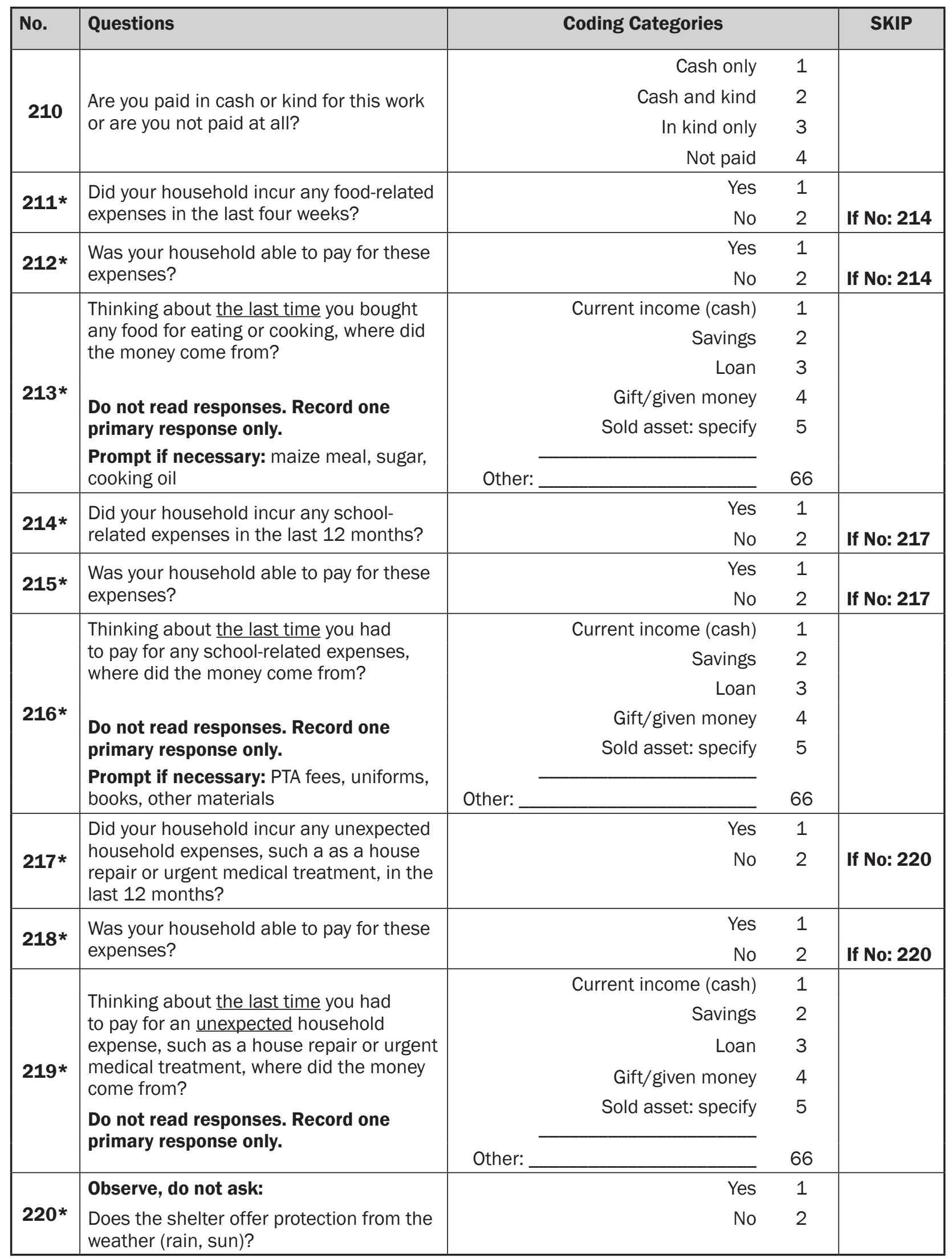




\begin{tabular}{|c|c|c|c|}
\hline No. & Questions & Coding Categories & \\
\hline \multirow{10}{*}{221} & \multirow{10}{*}{$\begin{array}{l}\text { Main material of the floor } \\
\text { Record observation }\end{array}$} & Earth/sand & 1 \\
\hline & & Dung & 2 \\
\hline & & Wood planks & 3 \\
\hline & & Palm/bamboo/reeds & 4 \\
\hline & & Parquet or polished wood & 5 \\
\hline & & Vinyl (PVC) or asphalt strips & 6 \\
\hline & & Ceramic/terrazzo tiles & 7 \\
\hline & & Concrete cement & 8 \\
\hline & & Carpet & 9 \\
\hline & & Other (specify): & 66 \\
\hline \multirow{14}{*}{222} & \multirow{14}{*}{$\begin{array}{l}\text { Main material of the roof } \\
\text { Record observation }\end{array}$} & No roof & 1 \\
\hline & & Thatch/palm leaf & 2 \\
\hline & & Rustic mat & 3 \\
\hline & & Palm/bamboo & 4 \\
\hline & & Wood planks & 5 \\
\hline & & Cardboard & 6 \\
\hline & & Metal/iron sheets & 7 \\
\hline & & Wood & 8 \\
\hline & & Calamine/cement fibers (asbestos) & 9 \\
\hline & & Ceramic tiles/Harvey tiles & 10 \\
\hline & & Cement & 11 \\
\hline & & Roofing shingles & 12 \\
\hline & & Mud tiles & 13 \\
\hline & & Other (specify): & 66 \\
\hline \multirow{14}{*}{223} & \multirow{14}{*}{$\begin{array}{l}\text { Main material of the exterior walls } \\
\text { Record observation }\end{array}$} & No walls & 1 \\
\hline & & Cane/palm/trunks & 2 \\
\hline & & Mud & 3 \\
\hline & & Bamboo/pole with mud & 4 \\
\hline & & Stone with mud & 5 \\
\hline & & Plywood & 6 \\
\hline & & Cardboard & 7 \\
\hline & & Reused wood & 8 \\
\hline & & Cement & 9 \\
\hline & & Stone with lime/cement & 10 \\
\hline & & Bricks & 11 \\
\hline & & Cement blocks & 12 \\
\hline & & Wood planks & 13 \\
\hline & & Other (specify): & 66 \\
\hline \multirow{3}{*}{224} & \multirow{3}{*}{$\begin{array}{l}\text { Compared to last year, do you feel that } \\
\text { your household is more or less financially } \\
\text { secure, or about the same? }\end{array}$} & More secure & 1 \\
\hline & & Less secure & 2 \\
\hline & & About the same & 3 \\
\hline
\end{tabular}




\begin{tabular}{|c|c|c|c|c|}
\hline No. & Questions & Coding Categories & & \\
\hline \multirow{22}{*}{225} & \multirow{11}{*}{ Does your household have a....? } & & Yes & No \\
\hline & & a) Radio & 1 & 2 \\
\hline & & b) Television & 1 & 2 \\
\hline & & c) Mobile telephone & 1 & 2 \\
\hline & & d) Non-mobile telephone & 1 & 2 \\
\hline & & e) Refrigerator & 1 & 2 \\
\hline & & f) Bed & 1 & 2 \\
\hline & & g) Chair & 1 & 2 \\
\hline & & h) Table & 1 & 2 \\
\hline & & i) Cupboard & 1 & 2 \\
\hline & & j) Sofa & 1 & 2 \\
\hline & \multirow{11}{*}{$\begin{array}{l}\text { Ask respondent about ownership } \\
\text { of each item, A to T, and record } \\
\text { response. }\end{array}$} & k) Clock & 1 & 2 \\
\hline & & l) Fan & 1 & 2 \\
\hline & & m) Sewing machine & 1 & 2 \\
\hline & & n) Cassette player & 1 & 2 \\
\hline & & o) Plough & 1 & 2 \\
\hline & & p) Grain grinder & 1 & 2 \\
\hline & & q) $\mathrm{VCR} / \mathrm{DVD}$ & 1 & 2 \\
\hline & & r) Tractor & 1 & 2 \\
\hline & & s) Hammer mill & 1 & 2 \\
\hline & & t) Satellite dish/decoder & 1 & 2 \\
\hline & & u) Watch & 1 & 2 \\
\hline \multirow{7}{*}{226} & \multirow{7}{*}{$\begin{array}{l}\text { Does your household have a....? } \\
\text { Ask respondent about ownership } \\
\text { of each item, A to F, and record } \\
\text { response. }\end{array}$} & & Yes & No \\
\hline & & a) Bicycle & 1 & 2 \\
\hline & & b) Animal-drawn cart & 1 & 2 \\
\hline & & c) Motorcycle, motor scooter & 1 & 2 \\
\hline & & d) Vehicle & 1 & 2 \\
\hline & & e) Boat with a motor & 1 & 2 \\
\hline & & f) Banana boat & 1 & 2 \\
\hline \multirow{10}{*}{227} & \multirow{3}{*}{$\begin{array}{l}\text { How many of each of the following } \\
\text { animals does this household own? }\end{array}$} & a) Traditional cattle & \multicolumn{2}{|c|}{ - } \\
\hline & & b) Dairy cattle & \multicolumn{2}{|c|}{$-\ldots$} \\
\hline & & c) Beef cattle & \multicolumn{2}{|c|}{ - } \\
\hline & \multirow{4}{*}{$\begin{array}{l}\text { Ask respondent about ownership } \\
\text { of each item, A to J, and record } \\
\text { response. }\end{array}$} & d) Horses, donkeys, or mules & \multicolumn{2}{|c|}{-} \\
\hline & & e) Goats & \multicolumn{2}{|c|}{$-\ldots$} \\
\hline & & f) Sheep & \multicolumn{2}{|c|}{$-\ldots$} \\
\hline & & g) Pigs & \multicolumn{2}{|c|}{$-\ldots$} \\
\hline & \multirow{3}{*}{$\begin{array}{l}\text { If none enter ' } 00 \text { '. } \\
\text { If unknown enter } 98 .\end{array}$} & h) Chickens & \multicolumn{2}{|c|}{-} \\
\hline & & i) Other poultry & \multicolumn{2}{|c|}{-} \\
\hline & & j) Other livestock & \multicolumn{2}{|c|}{ - } \\
\hline
\end{tabular}




\begin{tabular}{|c|c|c|c|c|}
\hline No. & Questions & Coding Categories & & SKIP \\
\hline 228 & $\begin{array}{l}\text { Does any member of your household } \\
\text { own any agricultural land? }\end{array}$ & $\begin{array}{l}\text { Yes } \\
\text { No }\end{array}$ & $\begin{array}{l}1 \\
2\end{array}$ & $\begin{array}{l}\text { No: } \\
230\end{array}$ \\
\hline 229 & $\begin{array}{l}\text { Approximately how many acres of } \\
\text { agricultural land do members of your } \\
\text { household own? }\end{array}$ & $\ldots$ acres/hectares (circle) & & \\
\hline 230 & $\begin{array}{l}\text { Approximately how much money did } \\
\text { your household spend on food in the } \\
\text { last one month? }\end{array}$ & [currency] & & \\
\hline 231 & $\begin{array}{l}\text { Was this more or less than the month } \\
\text { before, or about the same? }\end{array}$ & $\begin{array}{r}\text { More } \\
\text { Less } \\
\text { About the same }\end{array}$ & $\begin{array}{l}1 \\
2 \\
3\end{array}$ & $\begin{array}{l}\text { Less: } \\
233 \\
\text { Same: } \\
234\end{array}$ \\
\hline 232 & $\begin{array}{l}\text { Why did you spend more on food? } \\
\text { Record one primary response. }\end{array}$ & $\begin{array}{r}\text { More people in household now } \\
\text { Reduced household food stores } \\
\text { More disposable income } \\
\text { Food prices went up } \\
\text { Other: }\end{array}$ & $\begin{array}{c}1 \\
2 \\
3 \\
4 \\
66\end{array}$ & $\begin{array}{l}\text { All: } \\
234\end{array}$ \\
\hline 233 & $\begin{array}{l}\text { Why did you spend less on food? } \\
\text { Record one primary response. }\end{array}$ & $\begin{array}{r}\text { Fewer people in household now } \\
\text { Harvest produced food; no need to buy } \\
\text { Received food support } \\
\text { Food prices went down } \\
\text { Other: }\end{array}$ & $\begin{array}{c}1 \\
2 \\
3 \\
4 \\
66\end{array}$ & \\
\hline 234 & $\begin{array}{l}\text { Approximately how much money did } \\
\text { your household spend on healthcare } \\
\text { in the last one month? }\end{array}$ & _[currency] & & \\
\hline 235 & $\begin{array}{l}\text { Was this more or less than the month } \\
\text { before, or about the same? }\end{array}$ & $\begin{array}{r}\text { More } \\
\text { Less } \\
\text { About the same }\end{array}$ & $\begin{array}{l}1 \\
2 \\
3\end{array}$ & $\begin{array}{l}\text { Less: } \\
237 \\
\text { Same: } \\
238 \\
\end{array}$ \\
\hline 236 & $\begin{array}{l}\text { Why did you spend more on } \\
\text { healthcare? } \\
\text { Record one primary response. }\end{array}$ & $\begin{array}{l}\text { Household member pregnant/had baby } \\
\text { Had to buy drugs } \\
\text { Routine check-up occurred this month } \\
\text { Other }\end{array}$ & $\begin{array}{c}1 \\
2 \\
3 \\
4 \\
66\end{array}$ & $\begin{array}{l}\text { All: } \\
238\end{array}$ \\
\hline 237 & $\begin{array}{l}\text { Why did you spend less on } \\
\text { healthcare? } \\
\text { Record one primary response. }\end{array}$ & No one was sick & $\begin{array}{l}1 \\
2\end{array}$ & \\
\hline 238 & $\begin{array}{l}\text { Approximately how much money did } \\
\text { your household spend on education } \\
\text { expenses in the last } 12 \text { months? }\end{array}$ & _[currency] & & \\
\hline
\end{tabular}




\begin{tabular}{|c|c|c|c|c|}
\hline No. & Questions & Coding Categories & & SKIP \\
\hline 239 & $\begin{array}{l}\text { Was this more or less than the } \underline{12} \\
\text { months prior, or about the same? }\end{array}$ & $\begin{array}{r}\text { More } \\
\text { Less } \\
\text { About the same }\end{array}$ & $\begin{array}{l}1 \\
2 \\
3\end{array}$ & $\begin{array}{l}\text { Less: } \\
241 \\
\text { Same: } \\
242\end{array}$ \\
\hline 240 & $\begin{array}{l}\text { Why did you spend more on } \\
\text { education? } \\
\text { Record one primary response. }\end{array}$ & $\begin{array}{r}\begin{array}{r}\text { School fees increased } \\
\text { School requirements, such as: uniforms, } \\
\text { school books }\end{array} \\
\text { PTA costs or transportation costs increased } \\
\text { Number of school going members in the } \\
\text { household increased } \\
\text { Other: }\end{array}$ & $\begin{array}{l}1 \\
2 \\
3 \\
4 \\
66\end{array}$ & $\begin{array}{l}\text { All: } \\
242\end{array}$ \\
\hline 241 & $\begin{array}{l}\text { Why did you spend less on education? } \\
\text { Record one primary response. }\end{array}$ & $\begin{array}{l}\text { School fees reduced } \\
\text { PTA costs or transportation costs reduced } \\
\text { Number of school going members in the } \\
\text { household reduced }\end{array}$ & $\begin{array}{l}1 \\
2 \\
3\end{array}$ & \\
\hline 242 & $\begin{array}{l}\text { Approximately how much money did } \\
\text { your household spend on making } \\
\text { improvements to your home in the last } \\
12 \text { months? }\end{array}$ & [currency] & & \\
\hline 243 & $\begin{array}{l}\text { Was this more or less than the } \underline{12} \\
\text { months prior, or about the same? }\end{array}$ & $\begin{array}{r}\text { More } \\
\text { Less } \\
\text { About the same }\end{array}$ & $\begin{array}{l}1 \\
2 \\
3\end{array}$ & $\begin{array}{l}\text { Less: } \\
245 \\
\text { Same: } \\
301\end{array}$ \\
\hline 244 & $\begin{array}{l}\text { Why did you spend more? } \\
\text { Record one primary response. }\end{array}$ & $\begin{array}{l}\text { House was damaged in last } 12 \text { months } \\
\text { Had extra money for improvements } \\
\text { Other: }\end{array}$ & $\begin{array}{c}1 \\
2 \\
66\end{array}$ & $\begin{array}{l}\text { All: } \\
301\end{array}$ \\
\hline 245 & $\begin{array}{l}\text { Why did you spend less? } \\
\text { Record one primary response. }\end{array}$ & No improvements needed & $\begin{array}{c}1 \\
66\end{array}$ & \\
\hline \multicolumn{5}{|c|}{$\begin{array}{l}\text { Progress out of Poverty Index (PPI): We will now ask you a few more questions specifically designed to help us } \\
\text { measure the level of poverty in households. A couple of these questions may have already been asked, but we } \\
\text { appreciate your answers and your patience. }\end{array}$} \\
\hline 246 & $\begin{array}{l}\text { Are all household members ages } 7 \text { to } \\
16 \text { currently attending school? }\end{array}$ & $\begin{array}{r}\text { Yes } \\
\text { No } \\
\text { Nobody age } 7 \text { to } 16 \text { in household } \\
\end{array}$ & $\begin{array}{l}1 \\
2 \\
3\end{array}$ & \\
\hline 247 & $\begin{array}{l}\text { What is the highest grade that the } \\
\text { female head/spouse has attained? }\end{array}$ & $\begin{array}{r}\text { None, or first to fifth grade } \\
\text { Sixth grade } \\
\text { Seventh to ninth grade } \\
\text { No female head/spouse } \\
\text { Tenth grade or higher }\end{array}$ & $\begin{array}{l}1 \\
2 \\
3 \\
4 \\
5\end{array}$ & \\
\hline
\end{tabular}




\begin{tabular}{|c|c|c|c|c|}
\hline No. & Questions & Coding Categories & & SKIP \\
\hline 248 & $\begin{array}{l}\text { What is the main type of energy that } \\
\text { your household uses for cooking? }\end{array}$ & 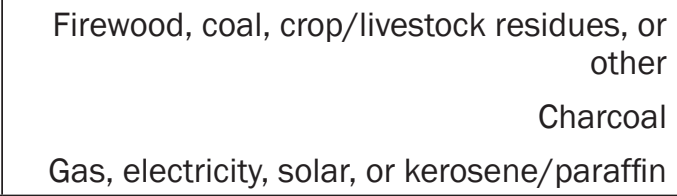 & $\begin{array}{l}1 \\
2 \\
3\end{array}$ & \\
\hline 249 & $\begin{array}{l}\text { Does your household own any non- } \\
\text { electric or electric irons? }\end{array}$ & $\begin{array}{r}\text { None } \\
\text { Only non-electric } \\
\text { Electric, or both electric and non-electric }\end{array}$ & $\begin{array}{l}1 \\
2 \\
3\end{array}$ & \\
\hline 250 & $\begin{array}{l}\text { How many beds and mattresses does } \\
\text { your household own? }\end{array}$ & $\begin{array}{r}\text { None } \\
\text { One or more beds, but no mattresses } \\
\text { One mattress (regardless of beds) } \\
\text { Two or more mattresses (regardless of beds) }\end{array}$ & $\begin{array}{l}1 \\
2 \\
3 \\
4\end{array}$ & \\
\hline
\end{tabular}

-END OF SECTION- 


\section{SECTION 3: HOUSEHOLD FOOD SECURITY}

Now I have a few questions about food consumption in your household.

\begin{tabular}{|c|c|c|c|c|c|}
\hline No. & Question & \multicolumn{3}{|l|}{ Coding Categories } & SKIP \\
\hline \multirow{13}{*}{301} & \multirow{7}{*}{$\begin{array}{l}\text { Now I would like to ask you about } \\
\text { the types of foods that you or } \\
\text { anyone in your household ate } \\
\text { yesterday during the day and at } \\
\text { night. }\end{array}$} & & Yes & No & \\
\hline & & a) Any maize, rice, wheat, or...? & 1 & 2 & \\
\hline & & $\begin{array}{l}\text { b) Any potatoes, yams, manioc, } \\
\text { cassava, or other foods made } \\
\text { from roots or tubers? }\end{array}$ & 1 & 2 & \\
\hline & & Any vegetables? & 1 & 2 & \\
\hline & & d) Any fruits? & 1 & 2 & \\
\hline & & $\begin{array}{l}\text { e) Any beef, pork, lamb, goat, } \\
\text { rabbit, wild game, chicken, } \\
\text { duck, or other birds, liver, } \\
\text { kidney, heart, or other organ } \\
\text { meats? }\end{array}$ & 1 & 2 & \\
\hline & & f) Any eggs? & 1 & 2 & \\
\hline & Read list of foods one at a time. & $\begin{array}{l}\text { g) Any fresh or dried fish or } \\
\text { shellfish? }\end{array}$ & 1 & 2 & \\
\hline & & $\begin{array}{l}\text { h) Any foods made from beans, } \\
\text { peas, lentils, or nuts? }\end{array}$ & 1 & 2 & \\
\hline & & $\begin{array}{l}\text { i) Any cheese, yogurt, milk, or } \\
\text { other milk products? }\end{array}$ & 1 & 2 & \\
\hline & & $\begin{array}{l}\text { j) Any foods made with oil, fat, or } \\
\text { butter? }\end{array}$ & 1 & 2 & \\
\hline & & k) Any sugar or honey? & 1 & 2 & \\
\hline & & $\begin{array}{l}\text { Any other foods, such as } \\
\text { condiments, coffee, tea? }\end{array}$ & 1 & 2 & \\
\hline $302 *$ & $\begin{array}{l}\text { In the past } 4 \text { weeks, was there ever } n \\
\text { household because of lack of resourc }\end{array}$ & $\begin{array}{l}\text { o food to eat of any kind in your } \\
\text { es to get food? }\end{array}$ & 1 & 2 & If No: 304 \\
\hline 303 & $\begin{array}{l}\text { How many times did this happen? } \\
\text { Read out responses }\end{array}$ & $\begin{array}{r}\text { Rarely (1-2 times in past } 4 \text { weeks) } \\
\text { Sometimes (3-10 times in past } 4 \\
\text { weeks) } \\
\text { Often (more than } 10 \text { times in past } \\
4 \text { weeks) }\end{array}$ & 2 & & \\
\hline 304 & $\begin{array}{l}\text { In the past } 4 \text { weeks, did you or any } \\
\text { household member go to sleep at } \\
\text { night hungry because there was not } \\
\text { enough food? }\end{array}$ & $\begin{array}{l}\text { Yes } \\
\text { No }\end{array}$ & $\begin{array}{l}1 \\
2\end{array}$ & & If No: $\mathbf{3 0 6}$ \\
\hline 305 & $\begin{array}{l}\text { How many times did this happen? } \\
\text { Read out responses }\end{array}$ & $\begin{array}{r}\text { Rarely (1-2 times in past } 4 \text { weeks) } \\
\text { Sometimes (3-10 times in past } 4 \\
\text { weeks) } \\
\text { Often (more than } 10 \text { times in past } \\
4 \text { weeks) }\end{array}$ & 1 & & \\
\hline
\end{tabular}




\begin{tabular}{|c|c|c|c|c|}
\hline 306 & $\begin{array}{l}\text { In the past } 4 \text { weeks, did you or any } \\
\text { member of your household go a } \\
\text { whole day and night without eating } \\
\text { anything because there was not } \\
\text { enough food? }\end{array}$ & $\begin{array}{l}\text { Yes } \\
\text { No }\end{array}$ & 2 & If No: 401 \\
\hline \multirow{3}{*}{307} & How many times did this happen? & Rarely (1-2 times in past 4 weeks) & 1 & \\
\hline & Read out responses & $\begin{array}{r}\text { Sometimes (3-10 times in past } 4 \\
\text { weeks) }\end{array}$ & 2 & \\
\hline & & $\begin{array}{r}\text { Often (more than } 10 \text { times in past } \\
4 \text { weeks) }\end{array}$ & 3 & \\
\hline
\end{tabular}

-END OF SECTION- 


\section{SECTION 4: CAREGIVER WELLBEING}

Next, I have some questions on your wellbeing.

\begin{tabular}{|c|c|c|c|c|}
\hline No. & Question & Coding Categorie & & SKIP \\
\hline 401 & $\begin{array}{l}\text { At any point in the last month, have you gone more than } \\
\text { one day when you were too sick or too tired to participate } \\
\text { in daily activities? }\end{array}$ & $\begin{array}{l}\text { Yes } \\
\text { No }\end{array}$ & $\begin{array}{l}1 \\
2\end{array}$ & $\begin{array}{l}\text { If No: } \\
403\end{array}$ \\
\hline 402 & $\begin{array}{l}\text { How often does it happen that you are too sick or too } \\
\text { tired to participate in daily activities? Would you say...? } \\
\text { Read out responses. }\end{array}$ & $\begin{array}{r}\text { Once in a while } \\
\text { At least once a week }\end{array}$ & $\begin{array}{l}1 \\
2\end{array}$ & \\
\hline $403 *$ & $\begin{array}{l}\text { Do you have someone in your life to turn to for } \\
\text { suggestions about how to deal with a personal problem? }\end{array}$ & $\begin{array}{l}\text { Yes } \\
\text { No }\end{array}$ & 2 & \\
\hline $404 *$ & $\begin{array}{l}\text { Do you have someone in your life to help with daily chores } \\
\text { if you were sick? }\end{array}$ & $\begin{array}{l}\text { Yes } \\
\text { No }\end{array}$ & 2 & \\
\hline $405 *$ & $\begin{array}{l}\text { Do you have someone in your life that shows you love and } \\
\text { affection? }\end{array}$ & $\begin{array}{l}\text { Yes } \\
\text { No }\end{array}$ & 2 & \\
\hline $406 *$ & $\begin{array}{l}\text { Do you have someone in your life to do something } \\
\text { enjoyable with? }\end{array}$ & $\begin{array}{l}\text { Yes } \\
\text { No }\end{array}$ & 2 & \\
\hline 407 & $\begin{array}{l}\text { Compared to other households in your community, how } \\
\text { well do you feel you can meet the needs of the children in } \\
\text { your care? Would you say ...? } \\
\text { Read out responses. }\end{array}$ & $\begin{array}{r}\text { Much better than } \\
\text { other households } \\
\text { A bit better than } \\
\text { other households } \\
\text { About the same as } \\
\text { other households } \\
\text { A bit worse than } \\
\text { other households } \\
\text { Much worse than } \\
\text { other households }\end{array}$ & $\begin{array}{l}2 \\
3\end{array}$ & \\
\hline 408 & $\begin{array}{l}\text { Do you think that hitting or beating a child is an } \\
\text { appropriate means of discipline or control in the home? }\end{array}$ & $\begin{array}{l}\text { Yes } \\
\text { No }\end{array}$ & 2 & \\
\hline 409 & $\begin{array}{l}\text { Do you think that hitting or beating a child is an } \\
\text { appropriate means of discipline or control at school? }\end{array}$ & $\begin{array}{c}\text { Yes } \\
\text { No }\end{array}$ & 1 & \\
\hline
\end{tabular}




\section{SECTION 5: GENDER ATTITUDES}

Now I have some questions about who makes decisions in your household.

\begin{tabular}{|c|c|c|c|c|}
\hline No. & Questions & Coding Categories & & SKIP \\
\hline 501 & $\begin{array}{l}\text { FILTER } \\
\text { Do you have a husband/wife or partner? }\end{array}$ & $\begin{array}{r}\text { Yes } \\
\text { No }\end{array}$ & $\begin{array}{l}1 \\
2\end{array}$ & \begin{tabular}{|l|} 
If No: \\
509
\end{tabular} \\
\hline 502 & $\begin{array}{l}\text { FILTER } \\
\text { Is respondent female or male? }\end{array}$ & $\begin{array}{r}\text { Female } \\
\text { Male }\end{array}$ & $\begin{array}{l}1 \\
2\end{array}$ & $\begin{array}{l}\text { If Male: } \\
508\end{array}$ \\
\hline 503 & $\begin{array}{l}\text { WOMEN ONLY } \\
\text { Who usually decides how the money that you } \\
\text { earn will be used: you, your husband/partner, } \\
\text { or you and your husband/partner jointly? }\end{array}$ & $\begin{array}{r}\text { Respondent } \\
\text { Husband/Partner } \\
\text { Respondent and } \\
\text { Husband/Partner jointly } \\
\text { I don't earn any money } \\
\text { Other }\end{array}$ & $\begin{array}{c}1 \\
2 \\
3 \\
4 \\
46\end{array}$ & \\
\hline 504 & $\begin{array}{l}\text { WOMEN ONLY } \\
\text { Who usually makes decisions about health } \\
\text { care for yourself: you, your husband/partner, } \\
\text { you and your husband/partner jointly, or } \\
\text { someone else? }\end{array}$ & $\begin{array}{r}\text { Respondent } \\
\text { Husband/Partner } \\
\text { Respondent and } \\
\text { Husband/Partner jointly } \\
\text { Other }\end{array}$ & $\begin{array}{l}1 \\
2 \\
3 \\
66\end{array}$ & \\
\hline 505 & $\begin{array}{l}\text { WOMEN ONLY } \\
\text { Who usually makes decisions about making } \\
\text { major household purchases? }\end{array}$ & $\begin{array}{r}\text { Respondent } \\
\text { Husband/Partner } \\
\text { Respondent and } \\
\text { Husband/Partner jointly } \\
\text { Other }\end{array}$ & $\begin{array}{l}3 \\
66\end{array}$ & \\
\hline 506 & $\begin{array}{l}\text { WOMEN ONLY } \\
\text { Who usually makes decisions about making } \\
\text { purchases for daily household needs? }\end{array}$ & $\begin{array}{r}\text { Respondent } \\
\text { Husband/Partner } \\
\text { Respondent and } \\
\text { Husband/Partner jointly } \\
\text { Other }\end{array}$ & $\begin{array}{l}1 \\
2 \\
3 \\
66\end{array}$ & \\
\hline 507 & $\begin{array}{l}\text { WOMEN ONLY } \\
\text { Who usually makes decisions about visits to } \\
\text { your family or relatives? }\end{array}$ & $\begin{array}{r}\text { Respondent } \\
\text { Husband/Partner } \\
\text { Respondent and } \\
\text { Husband/Partner jointly } \\
\text { Other }\end{array}$ & $\begin{array}{l}1 \\
2 \\
3 \\
66\end{array}$ & $\begin{array}{l}\text { All: } \\
509\end{array}$ \\
\hline 508 & $\begin{array}{l}\text { MEN ONLY } \\
\text { Who usually decides how the money that you } \\
\text { earn will be used: you, your wife/partner, or } \\
\text { you and your wife/partner jointly? }\end{array}$ & $\begin{array}{r}\text { Respondent } \\
\text { Wife/Partner } \\
\text { Respondent and Wife/ } \\
\text { Partner jointly } \\
\text { I don't earn any money } \\
\text { Other }\end{array}$ & $\begin{array}{c}4 \\
66\end{array}$ & \\
\hline
\end{tabular}




\begin{tabular}{|c|c|c|c|c|c|c|}
\hline No. & Questions & & Codir & Cat & ories & SKIP \\
\hline \multirow{6}{*}{509} & \multirow{6}{*}{$\begin{array}{l}\text { MEN AND WOMEN } \\
\text { In a couple, who do you think } \\
\text { should have the greater say in } \\
\text { each of the following decisions: } \\
\text { the husband, the wife, or both } \\
\text { equally: }\end{array}$} & & Husband & Wit & $\begin{array}{l}\text { Both } \\
\text { equally }\end{array}$ & \\
\hline & & $\begin{array}{l}\text { a) making large } \\
\text { household } \\
\text { purchases? }\end{array}$ & 1 & 2 & 3 & \\
\hline & & $\begin{array}{l}\text { b) making small } \\
\text { daily household } \\
\text { purchases? }\end{array}$ & 1 & 2 & 3 & \\
\hline & & $\begin{array}{l}\text { c) deciding when to } \\
\text { visit the wife's family } \\
\text { or relatives? }\end{array}$ & 1 & 2 & 3 & \\
\hline & & $\begin{array}{l}\text { d) deciding what to } \\
\text { do with the money } \\
\text { she earns for her } \\
\text { work? }\end{array}$ & 1 & 2 & 3 & \\
\hline & & $\begin{array}{l}\text { e) deciding how } \\
\text { many children to } \\
\text { have? }\end{array}$ & 1 & 2 & 3 & \\
\hline \multirow{6}{*}{510} & \multirow{6}{*}{$\begin{array}{l}\text { MEN AND WOMEN } \\
\text { Do you agree or disagree with } \\
\text { the following statement? It is } \\
\text { acceptable for a husband to } \\
\text { beat his wife if: } \\
\text { Read out responses. }\end{array}$} & & Agree & \multicolumn{2}{|c|}{ Disagree } & \\
\hline & & $\begin{array}{r}\text { She goes out without } \\
\text { telling him }\end{array}$ & 1 & \multicolumn{2}{|r|}{2} & \\
\hline & & $\begin{array}{l}\text { She is not looking } \\
\text { after their children }\end{array}$ & 1 & \multicolumn{2}{|r|}{2} & \\
\hline & & She argues with him & 1 & \multicolumn{2}{|r|}{2} & \\
\hline & & $\begin{array}{r}\text { She refuses to have } \\
\text { sex with him }\end{array}$ & 1 & \multicolumn{2}{|r|}{2} & \\
\hline & & She burns the food & 1 & \multicolumn{2}{|r|}{2} & \\
\hline
\end{tabular}


SECTION 6: CAREGIVER HIV/AIDS KNOWLEDGE, ATTITUDES \& BEHAVIOR

\begin{tabular}{|c|c|c|c|c|c|c|}
\hline No. & Question & \multicolumn{4}{|c|}{ Coding Categories } & SKIP \\
\hline \multirow[b]{2}{*}{601} & \multirow{2}{*}{$\begin{array}{l}\text { Now I would like to talk about something } \\
\text { else. Have you ever heard of an illness called } \\
\text { AIDS? }\end{array}$} & & Yes & \multicolumn{2}{|l|}{1} & \multirow[b]{2}{*}{$\begin{array}{l}\text { If No: } \\
701\end{array}$} \\
\hline & & & No & 2 & & \\
\hline \multirow{3}{*}{602} & \multirow{3}{*}{$\begin{array}{l}\text { Can people reduce their chances of getting } \\
\text { the AIDS virus by having just one uninfected } \\
\text { sex partner who has no other sex partners? }\end{array}$} & & Yes & 1 & & \\
\hline & & & No & 2 & & \\
\hline & & & Don't know/Not sure & 88 & & \\
\hline \multirow{3}{*}{603} & \multirow{3}{*}{$\begin{array}{l}\text { Can people reduce their chance of getting } \\
\text { the AIDS virus by using a condom every time } \\
\text { they have sex? }\end{array}$} & & Yes & 1 & & \\
\hline & & & No & 2 & & \\
\hline & & & Don't know/Not sure & 88 & & \\
\hline \multirow{3}{*}{604} & \multirow{3}{*}{$\begin{array}{l}\text { Is it possible for a healthy-looking person to } \\
\text { have the AIDS virus? }\end{array}$} & & Yes & 1 & & \\
\hline & & & No & 2 & & \\
\hline & & & Don't know/Not sure & 88 & & \\
\hline \multirow{3}{*}{605} & \multirow{3}{*}{$\begin{array}{l}\text { Can people get the AIDS virus from mosquito } \\
\text { bites? }\end{array}$} & & Yes & 1 & & \\
\hline & & & No & 2 & & \\
\hline & & & Don't know/Not sure & 88 & & \\
\hline \multirow{3}{*}{606} & \multirow{3}{*}{$\begin{array}{l}\text { Can people get the AIDS virus by sharing } \\
\text { food with someone who has AIDS? }\end{array}$} & & Yes & 1 & & \\
\hline & & & No & 2 & & \\
\hline & & & Don't know/Not sure & 88 & & \\
\hline \multirow{4}{*}{607} & \multirow{4}{*}{$\begin{array}{l}\text { Can the virus that causes AIDS be } \\
\text { transmitted from a mother to her baby: }\end{array}$} & & & Yes & DK & \\
\hline & & a) & During pregnancy? & 2 & 8 & \\
\hline & & b) & During delivery? & 2 & 8 & \\
\hline & & c) & By breastfeeding? & 1 & 8 & \\
\hline \multirow[b]{2}{*}{608} & \multirow[b]{2}{*}{$\begin{array}{l}\text { Have you ever been tested to see if you have } \\
\text { the AIDS virus? }\end{array}$} & & & Yes & 1 & \\
\hline & & & & No & 2 & $\begin{array}{l}\text { If No: } \\
611\end{array}$ \\
\hline \multirow{2}{*}{609} & \multirow{2}{*}{ Did you get the results of the test? } & & & Yes & 1 & \\
\hline & & & & No & 2 & \\
\hline \multirow{4}{*}{610} & \multirow{4}{*}{$\begin{array}{l}\text { Would you tell me the result of the test? We } \\
\text { will keep the result completely confidential. }\end{array}$} & & & Positive & 1 & \\
\hline & & & & Negative & 2 & \\
\hline & & & & Indeterminate & 3 & \\
\hline & & & & No answer & 4 & \\
\hline \multirow{2}{*}{611} & \multirow{2}{*}{$\begin{array}{l}\text { Do you know of a place where people can go } \\
\text { to get tested for the AIDS virus? }\end{array}$} & & & Yes & 1 & \\
\hline & & & & No & 2 & \\
\hline \multirow{2}{*}{611} & \multirow{2}{*}{$\begin{array}{l}\text { Should children age } 12-14 \text { be taught about } \\
\text { using a condom to avoid getting AIDS? }\end{array}$} & & & Yes & 1 & \\
\hline & & & & No & 2 & \\
\hline
\end{tabular}




\begin{tabular}{|c|c|c|c|c|}
\hline No. & Question & Coding Categories & & SKIP \\
\hline \multirow{3}{*}{612} & \multirow{3}{*}{$\begin{array}{l}\text { Would you buy fresh vegetables from a } \\
\text { shopkeeper or vendor if you knew that this } \\
\text { person had the AIDS virus? }\end{array}$} & Yes & 1 & \\
\hline & & No & 2 & \\
\hline & & Don't know/Not sure & 88 & \\
\hline \multirow{3}{*}{613} & \multirow{3}{*}{$\begin{array}{l}\text { If a member of your family got infected with } \\
\text { the AIDS virus, would you want it to remain a } \\
\text { secret or not? }\end{array}$} & Yes & 1 & \\
\hline & & No & 2 & \\
\hline & & Don't know/Not sure & 88 & \\
\hline \multirow{3}{*}{614} & \multirow{3}{*}{$\begin{array}{l}\text { If a member of your family became sick with } \\
\text { AIDS, would you be willing to care for her or } \\
\text { him in your own household? }\end{array}$} & Yes & 1 & \\
\hline & & No & 2 & \\
\hline & & Don't know/Not sure & 88 & \\
\hline \multirow{3}{*}{615} & \multirow{3}{*}{$\begin{array}{l}\text { In your opinion, if a female teacher has the } \\
\text { AIDS virus but is not sick, should she be } \\
\text { allowed to continue teaching in the school? }\end{array}$} & Yes & 1 & \\
\hline & & No & 2 & \\
\hline & & Don't know/Not sure & 88 & \\
\hline
\end{tabular}

-END OF SECTION- 


\section{SECTION 7: ACCESS TO HIV PREVENTION, CARE AND SUPPORT}

\begin{tabular}{|c|c|c|c|c|c|}
\hline No. & \multicolumn{3}{|c|}{ Question } & \multicolumn{2}{|c|}{ Coding Category } \\
\hline \multirow{15}{*}{701} & \multirow{15}{*}{$\begin{array}{l}\text { I am going to read out a } \\
\text { list of items and services. } \\
\text { Please tell me if you } \\
\text { or anyone else in your } \\
\text { household has received } \\
\text { or accessed any of these } \\
\text { items or services in the } \\
\text { last } 6 \text { months. }\end{array}$} & $\begin{array}{l}\text { a) } \\
\text { i) } \\
\text { ii) } \\
\text { iii) } \\
\text { iv) }\end{array}$ & $\begin{array}{l}\text { Cash } \\
\text { Government } \\
\text { NGO } \\
\text { Friends/family } \\
\text { Other: }\end{array}$ & Yes (amount) & $\begin{array}{l}\text { No } \\
2 \\
2 \\
2 \\
2\end{array}$ \\
\hline & & b) 1 & HIV test & Yes & No \\
\hline & & c) $\begin{array}{c}1 \\
1 \\
y\end{array}$ & $\begin{array}{l}\text { Nutritional advice in caring for } \\
\text { your children }\end{array}$ & Yes & No \\
\hline & & d) & Free food or vitamins & Yes & No \\
\hline & & e) & $\begin{array}{l}\text { Information on how to prevent } \\
\text { HIV and other sexually } \\
\text { transmitted infections }\end{array}$ & Yes & No \\
\hline & & f) & Information on birth spacing & Yes & No \\
\hline & & g) & Livelihood training & Yes & No \\
\hline & & h) ( & Community savings group & Yes & No \\
\hline & & i) & Life skills training & Yes & No \\
\hline & & j) & $\begin{array}{l}\text { Psychosocial support from a } \\
\text { home visitor or social worker }\end{array}$ & Yes & No \\
\hline & & k) & $\begin{array}{l}\text { Free school supplies or a } \\
\text { school uniform }\end{array}$ & Yes & No \\
\hline & & 1) & Birth registration support & Yes & No \\
\hline & & m) & $\begin{array}{l}\text { Paralegal support (wills, } \\
\text { succession planning) }\end{array}$ & Yes & No \\
\hline & & n) $\quad$ & Malaria prevention education & Yes & No \\
\hline & & o) 1 & Mosquito net & Yes & No \\
\hline
\end{tabular}

\section{-END OF SECTION-}

I have come to the end of my questions about you and your household. I would now like to ask you some questions about [name].

013 END TIME

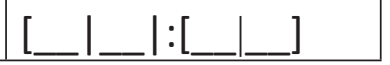

Check question 116 for name of child aged 0-9, apply Child Questionnaire 0-9 years to Caregiver.

Check question 121 for child aged 10-17, apply Child Questionnaire directly with Child, with both parental consent and child assent. 


\section{Children Aged 0 to 9 Questionnaire}

Adapted from: MEASURE Evaluation Children aged 0 to 9 years Questionnaire, Version 1.4

IDENTIFICATION DATA

\begin{tabular}{|c|l|c|}
\hline $\mathbf{0 0 1}$ & QUESTIONNAIRE IDENTIFICATION NUMBER & \\
\hline $\mathbf{0 0 2}$ & ZAMFAM DATABASE NUMBER & \\
\hline $\mathbf{0 0 3}$ & PROVINCE OR STATE & \\
\hline $\mathbf{0 0 4}$ & DISTRICT OR LOCAL GOVERNMENT AREA & \\
\hline $\mathbf{0 0 5}$ & CONSTITUENCY & \\
\hline $\mathbf{0 0 6}$ & WARD & \\
\hline $\mathbf{0 0 7}$ & TYPE OF LOCATION & Urban \\
\hline $\mathbf{0 0 8}$ & TOWN/VILLAGE & Rural \\
\hline $\mathbf{0 0 9}$ & NEIGHBOURHOOD & \\
\hline
\end{tabular}

INTERVIEW LOG

\begin{tabular}{|l|c|c|c|}
\hline & VISIT 1 & VISIT 2 & VISIT 3 \\
\hline DATE (day/month/year) & & & \\
\hline INTERVIEWER COMMENTS & & & \\
\hline
\end{tabular}

Interview comment codes: Interview completed 1; Appointment made for later today 2; Appointment made for another day 3; Refused to continue and no appointment made 4; Other (Specify) 5

\begin{tabular}{|c|l|l|l|}
\hline $\mathbf{0 1 0}$ & INTERVIEWER & C) CODE & D) NAME \\
\hline $\mathbf{0 1 1}$ & DATE INTERVIEW COMPLETED (day/month/year) & \\
\hline $\mathbf{0 1 2}$ & START TIME & [_I__ I:_____ $]$ \\
\hline
\end{tabular}

CHECKED BY TEAM LEADER: Signature Date

\section{Comments:}




\section{SECTION 1: CHILD HEALTH \& PROTECTION}

I am now going to ask you a few questions about [insert child's name].

\begin{tabular}{|c|c|c|c|c|}
\hline No. & Question & \multicolumn{2}{|l|}{ Coding Category } & SKIP \\
\hline 101 & Record/Confirm Child's Name & & & \\
\hline 102 & $\begin{array}{l}\text { Record Child's Line Letter from Household } \\
\text { Schedule (Caregiver Questionnaire) }\end{array}$ & & & \\
\hline $103 *$ & Record/Confirm Child's Sex & $\begin{array}{r}\text { Female } \\
\text { Male }\end{array}$ & $\begin{array}{l}1 \\
2\end{array}$ & \\
\hline 104 & In what month and year was [NAME] born? & Month & & \\
\hline $105 *$ & $\begin{array}{l}\text { Remind me, how old was [NAME] at their last } \\
\text { birthday? } \\
\text { Confirm with } 104 \text { and adjust if necessary. Do } \\
\text { not leave blank. If unknown, ask caregiver to } \\
\text { estimate. }\end{array}$ & _] years & & \\
\hline 106 & $\begin{array}{l}\text { Would you say that in general [NAME's] health } \\
\text { is......? } \\
\text { Read out responses. }\end{array}$ & $\begin{array}{r}\text { Excellent } \\
\text { Very good } \\
\text { Good } \\
\text { Fair } \\
\text { Poor }\end{array}$ & $\begin{array}{l}1 \\
2 \\
3 \\
4 \\
5\end{array}$ & \\
\hline 107 * & $\begin{array}{l}\text { In the last } 2 \text { weeks, has [NAME] been too sick to } \\
\text { participate in daily activities? }\end{array}$ & $\begin{array}{l}\text { Yes } \\
\text { No }\end{array}$ & $\begin{array}{l}1 \\
2\end{array}$ & \\
\hline 108 & $\begin{array}{l}\text { Does [NAME] have a disability that makes it difficult } \\
\text { for him/her to participate in daily activities? }\end{array}$ & $\begin{array}{l}\text { Yes } \\
\text { No }\end{array}$ & $\begin{array}{l}1 \\
2\end{array}$ & $\begin{array}{l}\text { If No: } \\
110\end{array}$ \\
\hline 109 & How would you describe [NAME's] disability? & $\begin{array}{r}\text { Blind or partially blind } \\
\text { Deaf or partially deaf } \\
\text { Has difficulties learning } \\
\text { Physical } \\
\text { Other }\end{array}$ & $\begin{array}{l}1 \\
2 \\
3 \\
4 \\
66\end{array}$ & \\
\hline $110 *$ & Does [NAME] have a birth certificate? & $\begin{array}{r}\text { Yes } \\
\text { No } \\
\text { Don't know }\end{array}$ & $\begin{array}{c}1 \\
2 \\
88\end{array}$ & $\begin{array}{l}\text { If No: } \\
112 \\
\text { If DK: } \\
112\end{array}$ \\
\hline $111 *$ & $\begin{array}{l}\text { Could you please show me [NAME's] birth } \\
\text { certificate? }\end{array}$ & $\begin{array}{r}\text { Seen/confirmed } \\
\text { Not seen/not confirmed }\end{array}$ & $\begin{array}{l}1 \\
2\end{array}$ & \\
\hline
\end{tabular}




\begin{tabular}{|c|c|c|c|c|c|}
\hline No. & Question & \multicolumn{3}{|c|}{ Coding Category } & SKIP \\
\hline 112 & $\begin{array}{l}\text { FILTER. } \\
\text { Age of child }\end{array}$ & \multicolumn{2}{|r|}{$\begin{array}{r}5 \text { years or older } \\
0-4 \text { years }\end{array}$} & $\begin{array}{l}1 \\
2\end{array}$ & $\begin{array}{l}\text { If } 5+\text { years: } \\
128\end{array}$ \\
\hline $113 *$ & $\begin{array}{l}\text { Do you have a card where [NAME's] } \\
\text { vaccinations are written down? } \\
\text { If yes, ask for card. }\end{array}$ & & $\begin{array}{r}\text { Yes, seen } \\
\text { Yes, not seen } \\
\text { No } \\
\text { Don't know }\end{array}$ & $\begin{array}{c}1 \\
2 \\
3 \\
88\end{array}$ & $\begin{array}{l}\text { If No: } 113 \\
\text { If DK: } 113\end{array}$ \\
\hline \multirow{10}{*}{114 * } & \multirow{10}{*}{$\begin{array}{l}\text { Check name on card to make sure card } \\
\text { relates to child in question. } \\
\text { Document the vaccinations recorded on the } \\
\text { card. Only include documented vaccinations } \\
\text { here. }\end{array}$} & & $\begin{array}{c}\text { Yes, } \\
\text { documented }\end{array}$ & No & \\
\hline & & a) BCG & 1 & 2 & \\
\hline & & b) OPV 0 & 1 & 2 & \\
\hline & & c) OPV 1 & 1 & 2 & \\
\hline & & d) OPV 2 & 1 & 2 & \\
\hline & & e) OPV 3 & 1 & 2 & \\
\hline & & f) $\mathrm{DPT} 1$ & 1 & 2 & \\
\hline & & g) $\mathrm{DPT} 2$ & 1 & 2 & \\
\hline & & h) DPT 3 & 1 & 2 & \\
\hline & & i) Measles & 1 & 2 & \\
\hline \multicolumn{6}{|c|}{$\begin{array}{l}\text { If caregiver cannot produce a vaccination card for child, probe for vaccinations below. If you have } \\
\text { documented the vaccinations from a card, but there are gaps in the vaccination record, probe with questions } \\
\text { below. }\end{array}$} \\
\hline $115 *$ & $\begin{array}{l}\text { Has [NAME] received a vaccine against } \\
\text { tuberculosis, that is, an injection in the arm } \\
\text { or shoulder, that usually causes a scar? } \\
\text { (BCG) }\end{array}$ & & $\begin{array}{r}\text { Yes } \\
\text { No } \\
\text { Don't know }\end{array}$ & $\begin{array}{c}1 \\
2 \\
88\end{array}$ & \\
\hline $116 *$ & $\begin{array}{l}\text { Has [NAME] received the polio vaccine, that } \\
\text { is, drops in the mouth? }\end{array}$ & & $\begin{array}{r}\text { Yes } \\
\text { No } \\
\text { Don't know }\end{array}$ & $\begin{array}{c}1 \\
2 \\
88\end{array}$ & $\begin{array}{l}\text { If No: } 121 \\
\text { If DK: } 121\end{array}$ \\
\hline $117 *$ & $\begin{array}{l}\text { Has the child received OPVO, that is the first } \\
\text { polio vaccine normally received in the first } \\
\text { two weeks after birth? }\end{array}$ & & $\begin{array}{r}\text { Yes } \\
\text { No } \\
\text { Don't know }\end{array}$ & $\begin{array}{c}1 \\
2 \\
88\end{array}$ & \\
\hline $118 *$ & $\begin{array}{l}\text { Has the child received OPV1, that is the } \\
\text { second polio vaccine? }\end{array}$ & & $\begin{array}{r}\text { Yes } \\
\text { No } \\
\text { Don't know }\end{array}$ & $\begin{array}{c}1 \\
2 \\
88\end{array}$ & \\
\hline $119 *$ & $\begin{array}{l}\text { Has the child received OPV2, that is the } \\
\text { third polio vaccine? }\end{array}$ & & $\begin{array}{r}\text { Yes } \\
\text { No } \\
\text { Don't know }\end{array}$ & $\begin{array}{c}1 \\
2 \\
88\end{array}$ & \\
\hline 120 * & $\begin{array}{l}\text { Has the child received OPV } 3 \text {, that is the } \\
\text { fourth polio vaccine? }\end{array}$ & & $\begin{array}{r}\text { Yes } \\
\text { No } \\
\text { Don't know }\end{array}$ & $\begin{array}{c}1 \\
2 \\
88\end{array}$ & \\
\hline
\end{tabular}




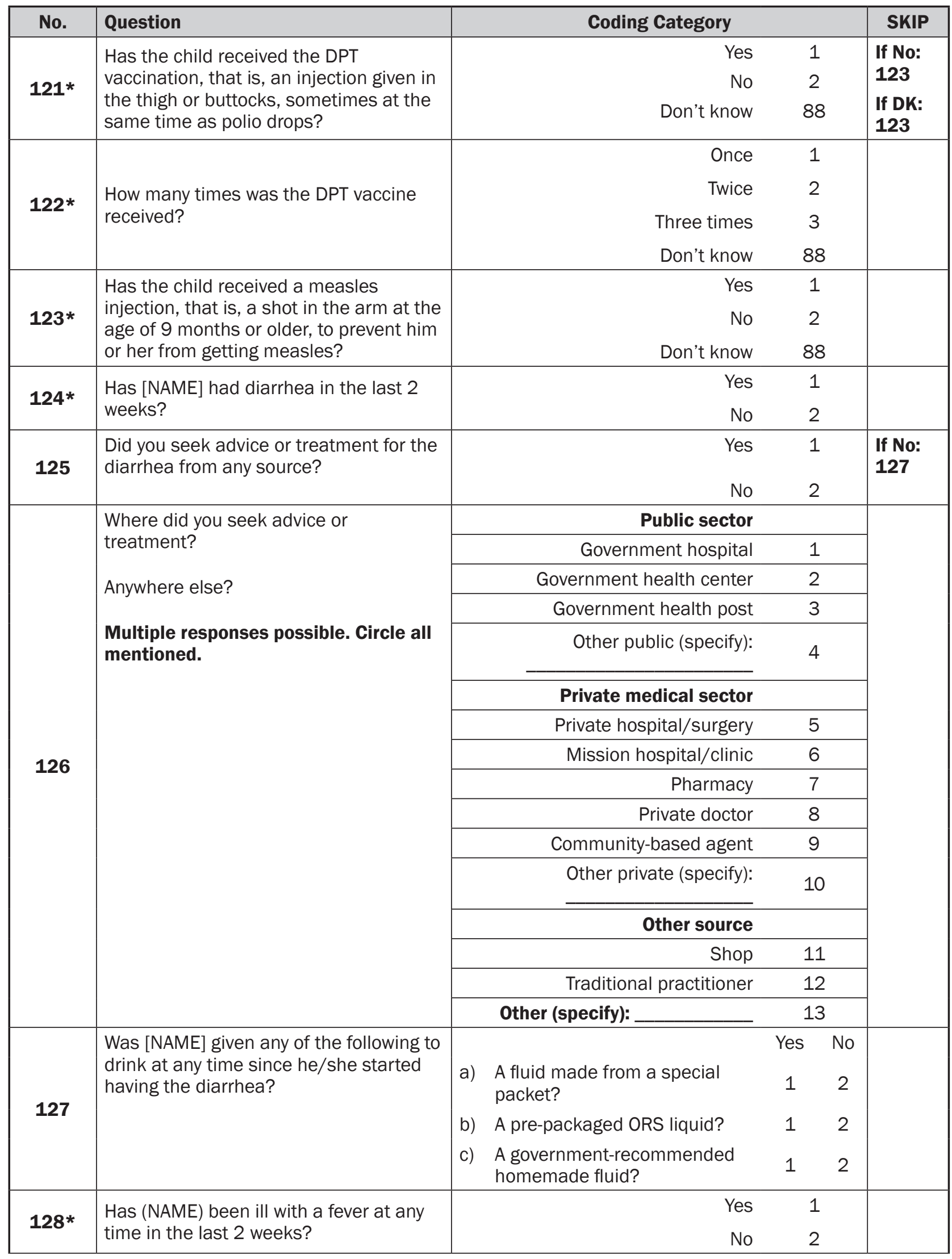




\begin{tabular}{|c|c|c|c|c|}
\hline 129 & $\begin{array}{l}\text { Did you seek advice or treatment for the } \\
\text { fever from any source? }\end{array}$ & $\begin{array}{l}\text { Yes } \\
\text { No }\end{array}$ & $\begin{array}{l}1 \\
2\end{array}$ & $\begin{array}{l}\text { If No: } \\
131\end{array}$ \\
\hline \multirow{16}{*}{130} & \multirow{16}{*}{$\begin{array}{l}\text { Where did you seek advice or } \\
\text { treatment? } \\
\text { Anywhere else? } \\
\text { Multiple responses possible. Circle all } \\
\text { mentioned. }\end{array}$} & Public sector & & \\
\hline & & Government hospital & 1 & \\
\hline & & Government health center & 2 & \\
\hline & & Government health post & 3 & \\
\hline & & Other public (specify): & 4 & \\
\hline & & Private medical sector & & \\
\hline & & Private hospital/surgery & 5 & \\
\hline & & Mission hospital/clinic & 6 & \\
\hline & & Pharmacy & 7 & \\
\hline & & Private doctor & 8 & \\
\hline & & Community-based agent & 9 & \\
\hline & & Other private (specify): & 10 & \\
\hline & & Other source & & \\
\hline & & Shop & 11 & \\
\hline & & Traditional practitioner & 12 & \\
\hline & & Other (specify): & 13 & \\
\hline \multirow{2}{*}{131} & \multirow{2}{*}{$\begin{array}{l}\text { At any time during the illness, did } \\
\text { [NAME] take any drugs for the illness? }\end{array}$} & Yes & 1 & \\
\hline & & No & 2 & \\
\hline 132 & $\begin{array}{l}\text { Sometimes adults taking care of } \\
\text { children have to leave the house to go } \\
\text { shopping, wash clothes, or for some } \\
\text { other reasons, and have to leave young } \\
\text { children. } \\
\text { On how many days in the past week was } \\
\text { [NAME] left alone for more than one } \\
\text { hour? }\end{array}$ & \multicolumn{2}{|l|}{ [___ ] days } & \\
\hline 133 & $\begin{array}{l}\text { On how many days in the past week was } \\
\text { [NAME] left in the care of another child } \\
\text { (that is, someone less than } 10 \text { years old) } \\
\text { for more than an hour? }\end{array}$ & \multicolumn{2}{|l|}{ [___ ] days } & \\
\hline \multirow{2}{*}{134} & \multirow{2}{*}{$\begin{array}{l}\text { Did [NAME] sleep under a mosquito net } \\
\text { last night? }\end{array}$} & Yes & 1 & \\
\hline & & No & 2 & \\
\hline
\end{tabular}

-END OF SECTION- 
SECTION 2: CHILD EDUCATION AND WORK

\begin{tabular}{|c|c|c|c|c|}
\hline No. & Question & Coding Category & & SKIP \\
\hline 201 & Filter: Age of child (Question 105) & $\begin{array}{r}5 \text { years or older } \\
3-4 \text { years } \\
0-2 \text { years }\end{array}$ & $\begin{array}{l}1 \\
2 \\
3\end{array}$ & $\begin{array}{l}\text { If } 3-4 \text { years: } \\
214 \\
\text { If } 0-2 \text { years: } \\
301\end{array}$ \\
\hline \multicolumn{5}{|c|}{ I now have some questions for you about [NAME's] schooling and chores. } \\
\hline 202* & Is [NAME] currently enrolled in school? & $\begin{array}{r}\text { Yes } \\
\text { No }\end{array}$ & $\begin{array}{l}1 \\
2\end{array}$ & If No: 206 \\
\hline 203* & $\begin{array}{l}\text { During the last school week, did } \\
\text { [NAME] miss any school days for any } \\
\text { reason? }\end{array}$ & $\begin{array}{c}\text { Yes } \\
\text { No }\end{array}$ & $\begin{array}{l}1 \\
2\end{array}$ & If No: 205 \\
\hline 204 & $\begin{array}{l}\text { Why did [NAME] miss school days } \\
\text { during the last school week? } \\
\text { Do not read responses. Circle one } \\
\text { primary response. }\end{array}$ & $\begin{array}{r}\text { No money for school fees, } \\
\text { materials, transport } \\
\text { Child was too sick to attend school } \\
\text { School is too far away/no school } \\
\text { Child had to work to help family } \\
\text { Child needed to care for sick } \\
\text { household members } \\
\text { Child does not like school } \\
\text { Other: }\end{array}$ & $\begin{array}{c}1 \\
2 \\
3 \\
4 \\
5 \\
6 \\
66\end{array}$ & \\
\hline 205* & $\begin{array}{l}\text { What grade/form/year is [NAME] in } \\
\text { now? }\end{array}$ & [_l_] & & All: 208 \\
\hline 206 & $\begin{array}{l}\text { Why is [NAME] not enrolled in school? } \\
\text { Do not read responses. Circle one } \\
\text { primary response. }\end{array}$ & $\begin{array}{r}\text { No money for school fees, } \\
\text { materials, transport } \\
\text { Child is too sick to attend school } \\
\text { School is too far away/no school } \\
\text { Child has to work to help family } \\
\text { Child needs to care for sick } \\
\text { household members } \\
\text { Child does not like school } \\
\text { Child is too young to attend school } \\
\text { Other: }\end{array}$ & $\begin{array}{l}1 \\
2 \\
3 \\
4 \\
5 \\
6 \\
7 \\
66\end{array}$ & \\
\hline 207 & Has [NAME] ever attended school? & $\begin{array}{r}\text { Yes } \\
\text { No } \\
\end{array}$ & $\begin{array}{l}1 \\
2\end{array}$ & If No: 211 \\
\hline 208* & $\begin{array}{l}\text { Was [NAME] enrolled in school during } \\
\text { the previous school year? }\end{array}$ & $\begin{array}{r}\text { Yes } \\
\text { No } \\
\end{array}$ & $\begin{array}{l}1 \\
2\end{array}$ & If No: 210 \\
\hline $209 *$ & $\begin{array}{l}\text { What grade/form/year was [NAME] in } \\
\text { during the previous school year? }\end{array}$ & [_l_] & & All: 211 \\
\hline 210 & $\begin{array}{l}\text { What is the highest grade/form/year } \\
\text { that [NAME] has completed? }\end{array}$ & [_l_] & & \\
\hline 211 & $\begin{array}{l}\text { In the past } 6 \text { months, has [NAME] } \\
\text { worked for money or kind? }\end{array}$ & $\begin{array}{r}\text { Yes } \\
\text { No }\end{array}$ & $\begin{array}{l}1 \\
2\end{array}$ & If No: 213 \\
\hline
\end{tabular}




\begin{tabular}{|c|c|c|c|c|c|}
\hline No. & Question & \multicolumn{3}{|c|}{ Coding Category } & SKIP \\
\hline 212 & $\begin{array}{l}\text { What did [NAME] do to earn these } \\
\text { wages? } \\
\text { Probe: Anything else? } \\
\text { Multiple responses possible. Circle } \\
\text { all mentioned. }\end{array}$ & $\begin{array}{r}\text { House chores, child ce } \\
\text { other } \\
\text { Selling/hawking } \\
\text { Labor, e.g., farm, constr } \\
\text { Other: }\end{array}$ & $\begin{array}{l}\text { e for } \\
\text { amily } \\
\text { oods } \\
\text { ction }\end{array}$ & $\begin{array}{c}1 \\
2 \\
3 \\
66\end{array}$ & \\
\hline 213* & $\begin{array}{l}\text { In the past } 3 \text { days, did you or any } \\
\text { household member over } 15 \text { years of } \\
\text { age engage in any of the following } \\
\text { activities with [NAME]: } \\
\text { Read out a through f one at a time. }\end{array}$ & $\begin{array}{l}\text { a) Read books to or } \\
\text { looked at picture } \\
\text { books with [NAME]? } \\
\text { b) Told stories to } \\
\text { [NAME]? } \\
\text { c) Sang songs to [NAME] } \\
\text { or with [NAME] } \\
\text { including lullabies? } \\
\text { d) Took [NAME] } \\
\text { outside of the home, } \\
\text { compound, yard, or } \\
\text { enclosure? } \\
\text { e) Played with [NAME]? } \\
\text { f) Named, counted, } \\
\text { or drew things with } \\
\text { [NAME]? }\end{array}$ & $\begin{array}{c}\text { Yes } \\
1 \\
1 \\
1 \\
1 \\
1 \\
1\end{array}$ & 2 & All: 301 \\
\hline 214 & $\begin{array}{l}\text { Does [NAME] attend any organized or } \\
\text { early childhood education program, } \\
\text { such as a private or government } \\
\text { facility, including kindergarten or } \\
\text { community child care? }\end{array}$ & & $\begin{array}{l}\text { Yes } \\
\text { No }\end{array}$ & $\begin{array}{l}1 \\
2\end{array}$ & \\
\hline
\end{tabular}


SECTION 3: FOOD CONSUMPTION

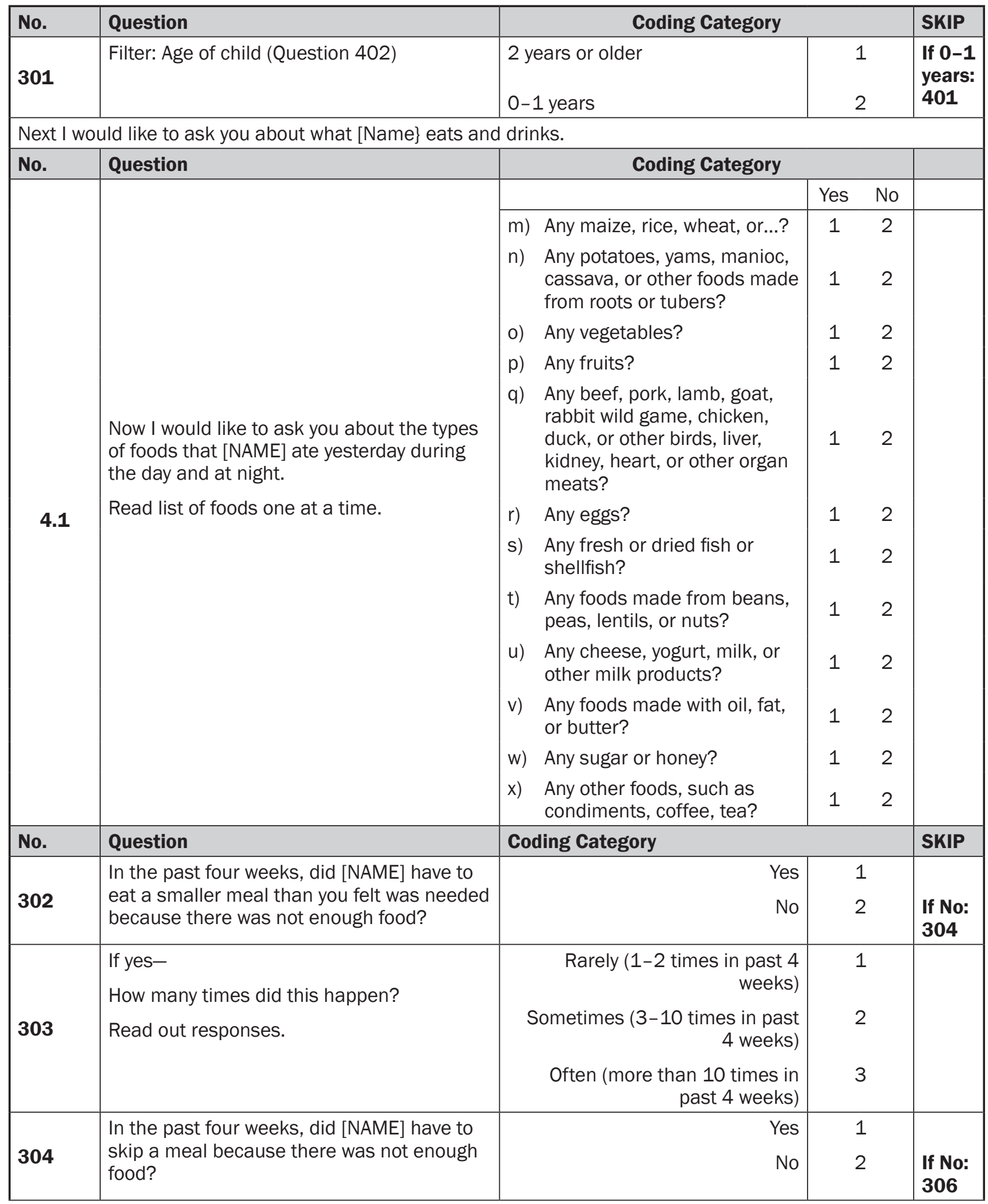




\begin{tabular}{|c|c|c|c|c|}
\hline No. & Question & Coding Category & & SKIP \\
\hline 305 & $\begin{array}{l}\text { If yes- } \\
\text { How many times did this happen? } \\
\text { Read out responses. }\end{array}$ & $\begin{array}{r}\text { Rarely (1-2 times in past } 4 \\
\text { weeks) } \\
\text { Sometimes (3-10 times in past } \\
4 \text { weeks) } \\
\text { Often (more than } 10 \text { times in } \\
\text { past } 4 \text { weeks) }\end{array}$ & $\begin{array}{l}1 \\
2 \\
3\end{array}$ & \\
\hline 306 & $\begin{array}{l}\text { In the past four weeks did [NAME] go to } \\
\text { sleep at night hungry because there was not } \\
\text { enough food to eat? }\end{array}$ & $\begin{array}{r}\text { Yes } \\
\text { No }\end{array}$ & $\begin{array}{l}1 \\
2\end{array}$ & $\begin{array}{l}\text { If No: } \\
308\end{array}$ \\
\hline 307 & $\begin{array}{l}\text { If yes- } \\
\text { How many times did this happen? } \\
\text { Read out responses. }\end{array}$ & $\begin{array}{r}\text { Rarely (1-2 times in past } 4 \\
\text { weeks) } \\
\text { Sometimes (3-10 times in past } \\
4 \text { weeks) } \\
\text { Often (more than } 10 \text { times in } \\
\text { past } 4 \text { weeks) }\end{array}$ & $\begin{array}{l}1 \\
2 \\
3\end{array}$ & \\
\hline $308 *$ & $\begin{array}{l}\text { In the past four weeks did [NAME] go a } \\
\text { whole day and night without eating anything } \\
\text { because there was not enough food to eat? }\end{array}$ & $\begin{array}{l}\text { Yes } \\
\text { No }\end{array}$ & $\begin{array}{l}1 \\
2\end{array}$ & \begin{tabular}{|l} 
If No: \\
401
\end{tabular} \\
\hline 309 & $\begin{array}{l}\text { If yes- } \\
\text { How many times did this happen? } \\
\text { Read out responses. }\end{array}$ & $\begin{array}{r}\text { Rarely (1-2 times in past } 4 \\
\text { weeks) } \\
\text { Sometimes (3-10 times in past } \\
4 \text { weeks) } \\
\text { Often (more than } 10 \text { times in } \\
\text { past } 4 \text { weeks) }\end{array}$ & $\begin{array}{l}2 \\
3\end{array}$ & \\
\hline
\end{tabular}




\section{SECTION 4: ACCESS TO HIV PREVENTION, CARE, AND SUPPORT}

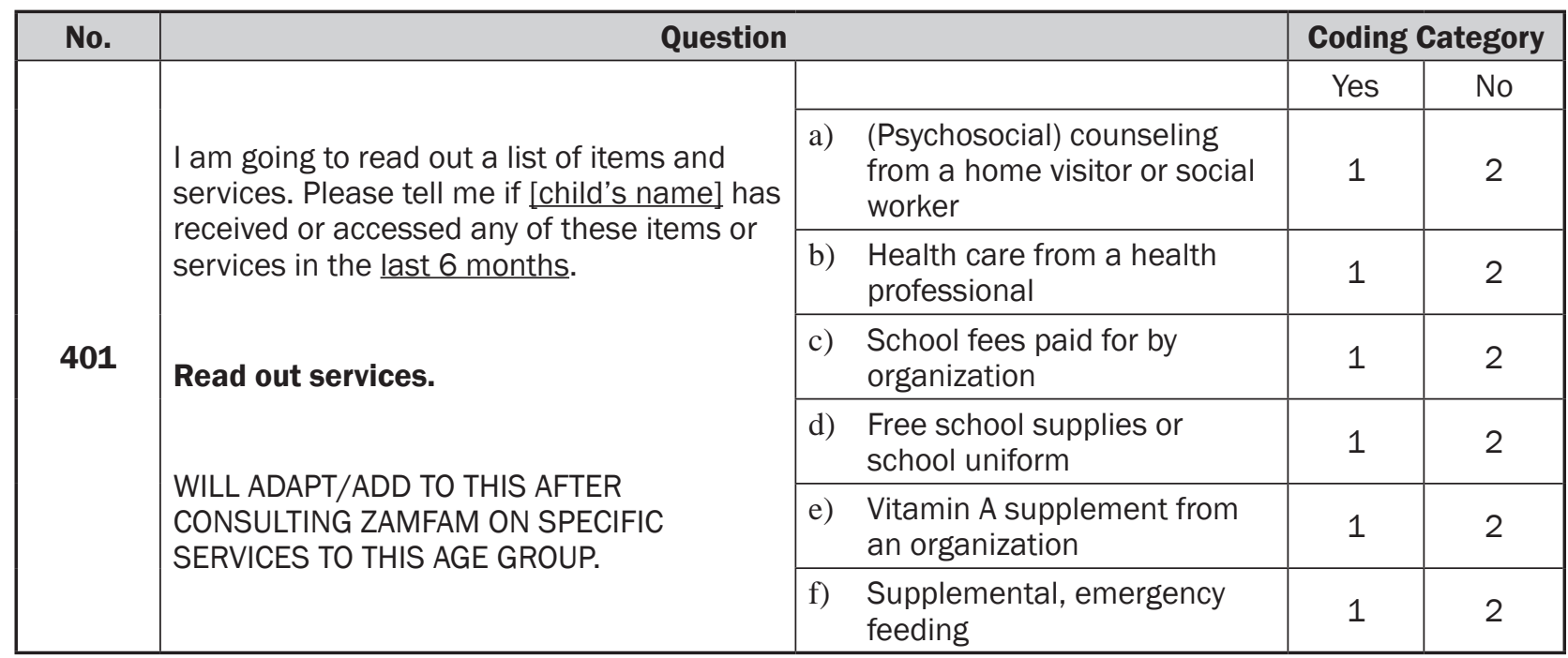

\section{-END OF SECTION-}

\section{SECTION 5: MUAC}

We are almost finished! May I measure your child's arm?

\begin{tabular}{|c|c|c|c|}
\hline No. & Questior & & Coding Category \\
\hline 501* & $\begin{array}{l}\text { Measure child's arm circumference. } \\
\text { Document measurement. }\end{array}$ & $\begin{array}{l}\text { a) } \\
\text { b) } \\
\text { a) MUAC }\end{array}$ & [_l__].[_l_] $\mathrm{Cm}$ \\
\hline
\end{tabular}

I have come to the end of my questions. Is there anything you would like to add or ask us?

Thank you for participating in this interview! 


\section{Children aged 10 to 17 Questionnaire}

Adapted from: MEASURE Evaluation Children aged 0 to 9 years Questionnaire, Version 1.4

IDENTIFICATION DATA

\begin{tabular}{|c|l|c|}
\hline $\mathbf{0 0 1}$ & QUESTIONNAIRE IDENTIFICATION NUMBER & \\
\hline $\mathbf{0 0 2}$ & ZAMFAM DATABASE NUMBER & \\
\hline $\mathbf{0 0 3}$ & PROVINCE OR STATE & \\
\hline $\mathbf{0 0 4}$ & DISTRICT OR LOCAL GOVERNMENT AREA & \\
\hline $\mathbf{0 0 5}$ & CONSTITUENCY & \\
\hline $\mathbf{0 0 6}$ & WARD & Urban \\
\hline $\mathbf{0 0 7}$ & TYPE OF LOCATION & Rural \\
\hline $\mathbf{0 0 8}$ & TOWN/VILLAGE & 2 \\
\hline $\mathbf{0 0 9}$ & NEIGHBOURHOOD & \\
\hline
\end{tabular}

INTERVIEW LOG

\begin{tabular}{|l|c|c|c|}
\hline & VISIT 1 & VISIT 2 & VISITI 3 \\
\hline DATE (day/month/year) & & & \\
\hline INTERVIEWER COMMENTS & & & \\
\hline
\end{tabular}

Interview comment codes: Interview completed 1; Appointment made for later today 2; Appointment made for another day 3; Refused to continue and no appointment made 4; Other (Specify) 5

\begin{tabular}{|l|l|l|l|}
\hline $\mathbf{0 1 0}$ & INTERVIEWER & E) CODE & F) NAME \\
\hline $\mathbf{0 1 1}$ & DATE INTERVIEW COMPLETED (day/month/year) & \\
\hline $\mathbf{0 1 2}$ & START TIME & [_I_I:[_I_ $]$ \\
\hline
\end{tabular}

CHECKED BY TEAM LEADER: Signature Date

\section{Comments}




\section{SECTION 1: BACKGROUND INFORMATION}

Let's start out by you telling me a little about yourself.

\begin{tabular}{|c|c|c|c|}
\hline No. & Questions & \multicolumn{2}{|c|}{ Coding Categories } \\
\hline 101 & $\begin{array}{l}\text { Record/Confirm Child's Name } \\
\text { What is your name? }\end{array}$ & & \\
\hline 102 & $\begin{array}{l}\text { Record Child's Line Letter from Household Schedule } \\
\text { (Caregiver Questionnaire) }\end{array}$ & & \\
\hline $103 *$ & Record/Confirm Child's Sex & $\begin{array}{r}\text { Female } \\
\text { Male }\end{array}$ & $\begin{array}{l}1 \\
2\end{array}$ \\
\hline 104 & In what month and year were you born? & $\begin{array}{l}\text { Month } \\
{[\ldots \text { ___ }]}\end{array}$ & - _ _ \\
\hline $105 *$ & $\begin{array}{l}\text { How old were you at your last birthday? } \\
\text { Confirm with } 104 \text { and adjust if necessary. Do not } \\
\text { leave blank. If child does not know, ask caregiver to } \\
\text { estimate age of child. }\end{array}$ & 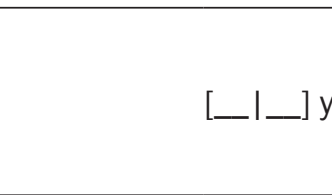 & \\
\hline 106 & $\begin{array}{l}\text { Who takes care of you? } \\
\text { Do not read responses. Record one primary } \\
\text { response only. }\end{array}$ & $\begin{array}{r}\text { Mother and/or father } \\
\text { Sister and/or brother } \\
\text { Aunt and/or uncle } \\
\text { Grandmother and/or } \\
\text { Grandfather } \\
\text { Other relative } \\
\text { Neighbor } \\
\text { Friend } \\
\text { No one/self } \\
\text { Other: }\end{array}$ & $\begin{array}{l}1 \\
2 \\
3 \\
4 \\
5 \\
6 \\
7 \\
8 \\
66\end{array}$ \\
\hline
\end{tabular}




\section{SECTION 2: DIARY}

I would like you to talk to me about your day yesterday. If yesterday wasn't a school day, ask about last school day.

\begin{tabular}{|c|c|c|c|c|}
\hline No. & Questions & Coding Categc & & SKIP \\
\hline 201 & $\begin{array}{l}\text { When did you get up-would you say, before the sun was up/it } \\
\text { got light or after the sun was up/it got light? }\end{array}$ & $\begin{array}{l}\text { Before sunrise } \\
\text { After sunrise }\end{array}$ & 1 & If After: 203 \\
\hline 202 & $\begin{array}{l}\text { And what did you do after you got up, but before it got light? } \\
\text { Anything else? }\end{array}$ & \multicolumn{3}{|c|}{ Mark X in all applicable boxes in diary } \\
\hline 203 & $\begin{array}{l}\text { Now, thinking about the time between when the sun came up/ } \\
\text { it got light and noon/the middle of the day, what did you do? } \\
\text { Anything else? }\end{array}$ & \multicolumn{3}{|c|}{ Mark X in all applicable boxes in diary } \\
\hline 204 & And around noon, what did you do? Anything else? & \multicolumn{3}{|c|}{ Mark X in all applicable boxes in diary } \\
\hline 205 & $\begin{array}{l}\text { Now, let's think about the time between noon sundown/when } \\
\text { it started to get dark, what did you do? Anything else? }\end{array}$ & \multicolumn{3}{|c|}{ Mark X in all applicable boxes in diary } \\
\hline 206 & $\begin{array}{l}\text { Now, let's think about after it got dark. What did you do before } \\
\text { you went to sleep? Anything else? }\end{array}$ & \multicolumn{3}{|c|}{ Mark X in all applicable boxes in diary } \\
\hline
\end{tabular}

Instructions: Ask about the time frames one at a time; probe for additional activities before going on to the next time frame. Every column should have at least one activity box marked. Multiple activities permitted. Do not read response options.

\begin{tabular}{|c|c|c|c|c|c|}
\hline \multirow[b]{2}{*}{ Activity } & \multicolumn{5}{|c|}{ Time } \\
\hline & 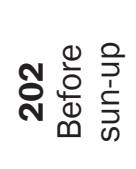 & 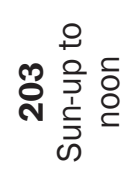 & ষั ণ ঠ & 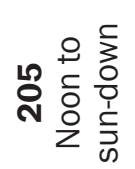 & ○㐫 \\
\hline \multicolumn{6}{|l|}{ Sleep } \\
\hline \multicolumn{6}{|l|}{ Meal } \\
\hline \multicolumn{6}{|l|}{ Household chores } \\
\hline \multicolumn{6}{|l|}{ Work on family/household farm } \\
\hline \multicolumn{6}{|l|}{ Care for household member-child } \\
\hline \multicolumn{6}{|l|}{ Care for household member-adult } \\
\hline \multicolumn{6}{|l|}{ School attendance } \\
\hline \multicolumn{6}{|l|}{ School work } \\
\hline \multicolumn{6}{|l|}{ Work (excluding household chores) } \\
\hline \multicolumn{6}{|l|}{ Informal recreation/leisure } \\
\hline \multicolumn{6}{|l|}{ Organized recreation/club } \\
\hline Other: specify & & & & & \\
\hline
\end{tabular}


SECTION 3: EDUCATION

\begin{tabular}{|c|c|c|c|c|}
\hline No. & Question & Coding Category & & SKIP \\
\hline \multirow{2}{*}{$301 *$} & \multirow{2}{*}{$\begin{array}{l}\text { Are you currently enrolled in } \\
\text { school? }\end{array}$} & Yes (correct diary) & 1 & If No: \\
\hline & & No & 2 & \\
\hline \multirow{2}{*}{$302 *$} & \multirow{2}{*}{$\begin{array}{l}\text { During the last school week, did } \\
\text { you miss any school days for any } \\
\text { reason? }\end{array}$} & Yes & 1 & If No: \\
\hline & & No & 2 & \\
\hline \multirow{10}{*}{303} & \multirow{10}{*}{$\begin{array}{l}\text { Why did you miss school days } \\
\text { during the last school week? } \\
\text { Do not read responses. Circle one } \\
\text { primary response. }\end{array}$} & No money for school materials, transport & 1 & \\
\hline & & I was too sick to attend school & 2 & \\
\hline & & School is too far away/no school & 3 & \\
\hline & & I had to work & 4 & \\
\hline & & I had to care for household members & 5 & \\
\hline & & Parent/guardian did not want me to go to & 6 & \\
\hline & & school & & \\
\hline & & I don't like school & 7 & \\
\hline & & School was not in session & 8 & \\
\hline & & Other: & 66 & \\
\hline $304 *$ & $\begin{array}{l}\text { What grade/form/year are you in } \\
\text { now? }\end{array}$ & [___ $]$ & & $\begin{array}{l}\text { All: } \\
307\end{array}$ \\
\hline \multirow{9}{*}{305} & \multirow{9}{*}{$\begin{array}{l}\text { Why do you NOT go to school? } \\
\text { Do not read responses. Circle one } \\
\text { primary response. }\end{array}$} & No money for school materials, transport & 1 & \\
\hline & & I am too sick to attend school & 2 & \\
\hline & & School is too far away/no school & 3 & \\
\hline & & I have to work & 4 & \\
\hline & & I have to care for household members & 5 & \\
\hline & & $\begin{array}{r}\text { Parent/guardian does not want me to go } \\
\text { to school }\end{array}$ & 6 & \\
\hline & & I don't like school & 7 & \\
\hline & & School was not in session & 8 & \\
\hline & & Other: & 66 & \\
\hline \multirow{2}{*}{306} & \multirow{2}{*}{ Have you ever attended school? } & Yes & 1 & If No: \\
\hline & & No & 2 & 401 \\
\hline \multirow{2}{*}{$307 *$} & \multirow{2}{*}{$\begin{array}{l}\text { Were you enrolled in school during } \\
\text { the previous school year? }\end{array}$} & Yes & 1 & If No: \\
\hline & & No & 2 & 309 \\
\hline $308 *$ & $\begin{array}{l}\text { What grade/form/year were you in } \\
\text { during the previous school year? }\end{array}$ & & [_l_ $]$ & $\begin{array}{l}\text { All: } \\
401\end{array}$ \\
\hline $309 *$ & $\begin{array}{l}\text { What is the highest grade/form/ } \\
\text { year that you have completed? }\end{array}$ & & [_l_ $]$ & \\
\hline
\end{tabular}




\section{SECTION 4: CHORES AND WORK}

\begin{tabular}{|c|c|c|c|c|}
\hline No. & Questions & Coding Categories & & SKIP \\
\hline 401 & $\begin{array}{l}\text { Check DIARY. Were the household chores } \\
\text { and/or care for your family or household, } \\
\text { mentioned? }\end{array}$ & $\begin{array}{l}\text { Yes } \\
\text { No }\end{array}$ & $\begin{array}{l}1 \\
2\end{array}$ & $\begin{array}{l}\text { If Yes: } \\
403\end{array}$ \\
\hline 402 & $\begin{array}{l}\text { Do you sometimes do household chores, or } \\
\text { care for a member of your household? }\end{array}$ & $\begin{array}{r}\text { Yes (correct diary) } \\
\text { No }\end{array}$ & $\begin{array}{l}1 \\
2\end{array}$ & $\begin{array}{l}\text { If No: } \\
405\end{array}$ \\
\hline 403 & $\begin{array}{l}\text { What household chores do you usually do? } \\
\text { Anything else? } \\
\text { Multiple responses possible; circle all } \\
\text { mentioned. Probe with response categories } \\
\text { if necessary. } \\
\text { Corroborate with diary. }\end{array}$ & $\begin{array}{r}\text { Prepare food } \\
\text { Fetch water } \\
\text { Clean toilets } \\
\text { Take care of children } \\
\text { Plant/tend to/harvest crops } \\
\text { Feed, care for animals } \\
\text { Wash clothes, blankets } \\
\text { Other: }\end{array}$ & $\begin{array}{l}1 \\
2 \\
3 \\
4 \\
6 \\
7 \\
8 \\
66\end{array}$ & \\
\hline 404 & $\begin{array}{l}\text { About how much time do you spend per day } \\
\text { doing household or farm chores for your } \\
\text { family? }\end{array}$ & 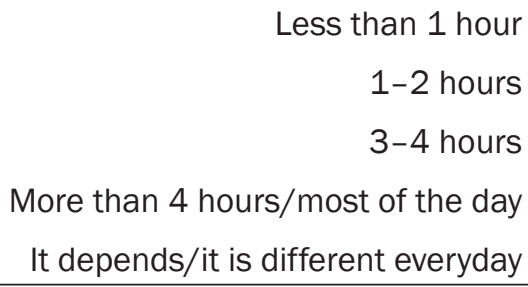 & $\begin{array}{l}1 \\
2 \\
3 \\
4 \\
5\end{array}$ & \\
\hline 405 & Check DIARY-Was other work mentioned? & $\begin{array}{l}\text { Yes } \\
\text { No }\end{array}$ & 1 & $\begin{array}{l}\text { If Yes: } \\
407\end{array}$ \\
\hline 406 & $\begin{array}{l}\text { Apart from these chores, do you sometimes } \\
\text { do other work outside your home? }\end{array}$ & $\begin{array}{r}\text { Yes (correct diary) } \\
\text { No }\end{array}$ & $\begin{array}{l}1 \\
2\end{array}$ & $\begin{array}{l}\text { If No: } \\
411\end{array}$ \\
\hline
\end{tabular}




\begin{tabular}{|c|c|c|c|c|}
\hline No. & Questions & Coding Categories & & SKIP \\
\hline 407 & $\begin{array}{l}\text { What kinds of other work do you sometimes } \\
\text { do? } \\
\text { Anything else? } \\
\text { Multiple responses possible; circle all } \\
\text { mentioned. Probe with response categories } \\
\text { if necessary. } \\
\text { Corroborate with diary. }\end{array}$ & $\begin{array}{r}\text { Hawk goods } \\
\text { Sell food at market } \\
\text { Household/farm chores for } \\
\text { other families } \\
\text { Work in a restaurant or bar } \\
\text { Help out in shop } \\
\text { Construction } \\
\text { Sewing } \\
\text { Mechanic } \\
\text { Clerk, Delivery, Administrative } \\
\text { Other: }\end{array}$ & $\begin{array}{l}1 \\
2 \\
3 \\
4 \\
5 \\
6 \\
7 \\
8 \\
9 \\
66\end{array}$ & \\
\hline 408 & $\begin{array}{l}\text { How often do you do other work? Would you } \\
\text { say....? } \\
\text { Read response categories }\end{array}$ & $\begin{array}{r}\text { Every day/most days } \\
\text { Several times a week } \\
\text { Once a week } \\
\text { Once in a while }\end{array}$ & $\begin{array}{l}1 \\
2 \\
3 \\
4\end{array}$ & $\begin{array}{l}\text { If Every day } \\
\text { (1): } 409 \\
\text { All others: } \\
410\end{array}$ \\
\hline 409 & $\begin{array}{l}\text { About how much time do you spend per day } \\
\text { doing this work? }\end{array}$ & $\begin{array}{r}\text { Less than } 1 \text { hour } \\
1-2 \text { hours } \\
3-4 \text { hours } \\
\text { More than } 4 \text { hours } \\
\text { It depends/it is different } \\
\text { everyday }\end{array}$ & $\begin{array}{l}1 \\
2 \\
3 \\
4 \\
5\end{array}$ & \\
\hline 410 & $\begin{array}{l}\text { Have you ever received money for any of the } \\
\text { work that you do? }\end{array}$ & $\begin{array}{l}\text { Yes } \\
\text { No }\end{array}$ & $\begin{array}{l}1 \\
2\end{array}$ & \\
\hline 411 & What [else] do you do to get money? & $\begin{array}{rr}\text { Nothing } \\
\text { Begging }\end{array}$ & $\begin{array}{c}1 \\
2 \\
66\end{array}$ & $\begin{array}{l}\text { If work } \\
\text { mentioned, } \\
\text { return to } \\
406-410 .\end{array}$ \\
\hline 412 & $\begin{array}{l}\text { What do you do with the money you get? } \\
\text { Anything else? } \\
\text { Multiple responses possible; circle all } \\
\text { mentioned. Probe with response categories } \\
\text { if necessary. }\end{array}$ & $\begin{array}{r}\text { Give to parents/guardians } \\
\text { Pay for my school expenses } \\
\text { Pay for school expenses of } \\
\text { others } \\
\text { Buy food for myself } \\
\text { Buy food for others } \\
\text { Buy other things for myself } \\
\text { Save it } \\
\text { Other: }\end{array}$ & $\begin{array}{l}1 \\
2 \\
3 \\
4 \\
5 \\
6 \\
7 \\
66\end{array}$ & \\
\hline
\end{tabular}




\section{SECTION 5: FOOD AND ALCOHOL CONSUMPTION}

Next I would like to ask you about what you eat and drink.

\begin{tabular}{|c|c|c|c|c|}
\hline No. & Question & \multicolumn{3}{|l|}{ Coding Category } \\
\hline \multirow{13}{*}{501} & \multirow{13}{*}{$\begin{array}{l}\text { Now I would like to ask you about the } \\
\text { types of foods that you ate yesterday } \\
\text { during the day and at night. } \\
\text { Read list of foods one at a time. }\end{array}$} & & Yes & No \\
\hline & & Any maize, rice, wheat, or...? & 1 & 2 \\
\hline & & $\begin{array}{l}\text { Any potatoes, yams, manioc, cassava, or } \\
\text { other foods made from roots or tubers? }\end{array}$ & 1 & 2 \\
\hline & & Any vegetables? & 1 & 2 \\
\hline & & Any fruits? & 1 & 2 \\
\hline & & $\begin{array}{l}\text { Any beef, pork, lamb, goat, rabbit wild game, } \\
\text { chicken, duck, or other birds, liver, kidney, } \\
\text { heart, or other organ meats? }\end{array}$ & 1 & 2 \\
\hline & & Any eggs? & 1 & 2 \\
\hline & & Any fresh or dried fish or shellfish? & 1 & 2 \\
\hline & & $\begin{array}{l}\text { Any foods made from beans, peas, lentils, or } \\
\text { nuts? }\end{array}$ & 1 & 2 \\
\hline & & $\begin{array}{l}\text { Any cheese, yogurt, milk, or other milk } \\
\text { products? }\end{array}$ & 1 & 2 \\
\hline & & Any foods made with oil, fat, or butter? & 1 & 2 \\
\hline & & Any sugar or honey? & 1 & 2 \\
\hline & & $\begin{array}{l}\text { Any other foods, such as condiments, coffee, } \\
\text { tea? }\end{array}$ & 1 & 2 \\
\hline No. & Question & \multicolumn{2}{|l|}{ Coding Category } & SKIP \\
\hline & In the past four weeks, did you have & Yes & 1 & \\
\hline 502 & $\begin{array}{l}\text { to eat a smaller meal than you felt you } \\
\text { needed because there was not enough } \\
\text { food? }\end{array}$ & No & 2 & $\begin{array}{l}\text { If No: } \\
504\end{array}$ \\
\hline \multirow{3}{*}{503} & If yes- & Rarely (1-2 times in past 4 weeks) & 1 & \\
\hline & How many times did this happen? & Sometimes (3-10 times in past 4 weeks) & 2 & \\
\hline & Read out responses. & Often (more than 10 times in past 4 weeks) & 3 & \\
\hline \multirow[b]{2}{*}{504} & \multirow{2}{*}{$\begin{array}{l}\text { In the past four weeks, did you have } \\
\text { to skip a meal because there was not } \\
\text { enough food? }\end{array}$} & Yes & 1 & \\
\hline & & No & 2 & $\begin{array}{l}\text { If No: } \\
506\end{array}$ \\
\hline \multirow{3}{*}{505} & If yes- & Rarely (1-2 times in past 4 weeks) & 1 & \\
\hline & How many times did this happen? & Sometimes (3-10 times in past 4 weeks) & 2 & \\
\hline & Read out responses. & Often (more than 10 times in past 4 weeks) & 3 & \\
\hline \multirow[b]{2}{*}{506} & \multirow{2}{*}{$\begin{array}{l}\text { In the past four weeks did you go to } \\
\text { sleep at night hungry because there } \\
\text { was not enough food to eat? }\end{array}$} & Yes & 1 & \\
\hline & & No & 2 & $\begin{array}{l}\text { If No: } \\
508\end{array}$ \\
\hline \multirow{3}{*}{507} & If yes- & Rarely (1-2 times in past 4 weeks) & 1 & \\
\hline & How many times did this happen? & Sometimes (3-10 times in past 4 weeks) & 2 & \\
\hline & Read out responses. & Often (more than 10 times in past 4 weeks) & 3 & \\
\hline
\end{tabular}




\begin{tabular}{|c|c|c|c|c|}
\hline No. & Question & Coding Category & & SKIP \\
\hline $508 *$ & $\begin{array}{l}\text { In the past four weeks did you go a } \\
\text { whole day and night without eating } \\
\text { anything because there was not } \\
\text { enough food to eat? }\end{array}$ & $\begin{array}{l}\text { Yes } \\
\text { No }\end{array}$ & $\begin{array}{l}1 \\
2\end{array}$ & $\begin{array}{l}\text { If No: } \\
510\end{array}$ \\
\hline 509 & $\begin{array}{l}\text { If yes- } \\
\text { How many times did this happen? } \\
\text { Read out responses. }\end{array}$ & $\begin{array}{r}\text { Rarely (1-2 times in past } 4 \text { weeks) } \\
\text { Sometimes (3-10 times in past } 4 \text { weeks) } \\
\text { Often (more than } 10 \text { times in past } 4 \text { weeks) }\end{array}$ & $\begin{array}{l}1 \\
2 \\
3\end{array}$ & \\
\hline 510 & $\begin{array}{l}\text { Have you ever consumed a drink } \\
\text { containing alcohol including beer, } \\
\text { spirits-that is a whole glass or drink, } \\
\text { not just a taste? }\end{array}$ & $\begin{array}{l}\text { Yes } \\
\text { No }\end{array}$ & $\begin{array}{l}1 \\
2\end{array}$ & $\begin{array}{l}\text { If No: } \\
601\end{array}$ \\
\hline 511 & $\begin{array}{l}\text { When was the last time you consumed } \\
\text { a drink containing alcohol? } \\
\text { Read out responses. }\end{array}$ & $\begin{array}{r}\text { Yesterday/a few days ago } \\
\text { About a week ago } \\
\text { More than a week ago }\end{array}$ & $\begin{array}{l}1 \\
2 \\
3\end{array}$ & \\
\hline 512 & $\begin{array}{l}\text { How often does it happen that you } \\
\text { consume a drink containing alcohol? } \\
\text { Read out responses. }\end{array}$ & $\begin{array}{l}\text { Only once in a while } \\
\text { At least once a week }\end{array}$ & $\begin{array}{l}1 \\
2\end{array}$ & \\
\hline
\end{tabular}




\section{SECTION 6: HEALTH, SUPPORT, AND PROTECTION}

Now I have a few questions about your health and wellbeing.

\begin{tabular}{|c|c|c|c|c|c|}
\hline No. & Question & & Coding Category & & SKIP \\
\hline $601 *$ & Do you have a birth certificate? & & $\begin{array}{r}\text { Yes } \\
\text { No } \\
\text { Don't know }\end{array}$ & $\begin{array}{c}1 \\
2 \\
88\end{array}$ & $\begin{array}{l}\text { If No: } \\
603 \\
\text { If DK: } \\
603 \\
\end{array}$ \\
\hline $602 *$ & $\begin{array}{l}\text { Could you please show me your birth } \\
\text { certificate? }\end{array}$ & & $\begin{array}{r}\text { Seen/confirmed } \\
\text { Not seen/not confirmed }\end{array}$ & $\begin{array}{l}1 \\
2\end{array}$ & \\
\hline $603 *$ & $\begin{array}{l}\text { At any point in the last } 2 \text { weeks, have } \\
\text { you been too sick to participate in daily } \\
\text { activities? }\end{array}$ & & $\begin{array}{l}\text { Yes } \\
\text { No }\end{array}$ & $\begin{array}{l}1 \\
2\end{array}$ & \\
\hline 604 & $\begin{array}{l}\text { Do you have a disability that makes it } \\
\text { difficult for you to participate in daily } \\
\text { activities? }\end{array}$ & & $\begin{array}{l}\text { Yes } \\
\text { No }\end{array}$ & $\begin{array}{l}1 \\
2\end{array}$ & $\begin{array}{l}\text { If No: } \\
606\end{array}$ \\
\hline 605 & How would you describe your disability? & Other & $\begin{array}{r}\text { Blind or partially blind } \\
\text { Deaf or partially deaf } \\
\text { I have difficulties learning } \\
\text { Physical } \\
\end{array}$ & $\begin{array}{l}1 \\
2 \\
3 \\
4 \\
66\end{array}$ & \\
\hline $606 *$ & $\begin{array}{l}\text { I'm going to ask you a few questions about } \\
\text { people in your life. Please respond yes or no. } \\
\text { Do you have someone in your life to turn to } \\
\text { for suggestions about how to deal with a } \\
\text { personal problem? }\end{array}$ & & $\begin{array}{l}\text { Yes } \\
\text { No }\end{array}$ & $\begin{array}{l}1 \\
2\end{array}$ & \\
\hline $607 *$ & $\begin{array}{l}\text { Do you have someone in your life to help } \\
\text { with daily chores if you are sick? }\end{array}$ & & $\begin{array}{l}\text { Yes } \\
\text { No }\end{array}$ & $\begin{array}{l}1 \\
2\end{array}$ & \\
\hline $608 *$ & $\begin{array}{l}\text { Do you have someone in your life that shows } \\
\text { you love and affection? }\end{array}$ & & $\begin{array}{l}\text { Yes } \\
\text { No }\end{array}$ & $\begin{array}{l}1 \\
2\end{array}$ & \\
\hline $609 *$ & $\begin{array}{l}\text { Do you have someone in your life to do } \\
\text { something enjoyable with? }\end{array}$ & & $\begin{array}{l}\text { Yes } \\
\text { No }\end{array}$ & $\begin{array}{l}1 \\
2\end{array}$ & \\
\hline
\end{tabular}




\section{SECTION 7: HIV/AIDS KNOWLEDGE, ATTITUDES, AND SEXUAL BEHAVIOR}

\section{Section restricted to ages 13-17 only}

We are nearly done. I have a few short questions on a disease called HIV/AIDS.

\begin{tabular}{|c|c|c|c|c|}
\hline No. & Question & \multicolumn{2}{|c|}{ Coding Categories } & SKIP \\
\hline 701 & $\begin{array}{l}\text { Has anyone ever talked to you or taught you } \\
\text { about how children grow and develop? } \\
\text { Prompt: how children's bodies change over } \\
\text { time (puberty changes) }\end{array}$ & $\begin{array}{r}\text { Yes } \\
\text { No }\end{array}$ & $\begin{array}{l}1 \\
2\end{array}$ & $\begin{array}{l}\text { If No: } \\
703\end{array}$ \\
\hline 702 & $\begin{array}{l}\text { Who talked to you about how children grow } \\
\text { and develop? } \\
\text { Anyone else? } \\
\text { Multiple responses possible. Circle all } \\
\text { mentioned. }\end{array}$ & $\begin{array}{r}\text { Teacher } \\
\text { Family/household } \\
\text { member } \\
\text { Other: }\end{array}$ & $\begin{array}{l}1 \\
2 \\
66\end{array}$ & \\
\hline 703 & $\begin{array}{l}\text { Has anyone ever talked to you or taught you } \\
\text { about sex or sexual behavior? }\end{array}$ & $\begin{array}{r}\text { Yes } \\
\text { No }\end{array}$ & $\begin{array}{l}1 \\
2\end{array}$ & $\begin{array}{l}\text { If No: } \\
705\end{array}$ \\
\hline 704 & $\begin{array}{l}\text { Who talked to you about sex or sexual } \\
\text { behavior? } \\
\text { Anyone else? } \\
\text { Multiple responses possible. Circle all } \\
\text { mentioned. }\end{array}$ & $\begin{array}{r}\text { Teacher } \\
\text { Family/household } \\
\text { member } \\
\text { Other: }\end{array}$ & $\begin{array}{l}1 \\
2 \\
66\end{array}$ & \\
\hline 705 & Have you ever heard of an illness called AIDS? & $\begin{array}{r}\text { Yes } \\
\text { No }\end{array}$ & $\begin{array}{l}1 \\
2\end{array}$ & $\begin{array}{l}\text { If No: } \\
801\end{array}$ \\
\hline 706 & $\begin{array}{l}\text { Has anyone ever talked to you or taught you } \\
\text { about HIV or AIDS? }\end{array}$ & $\begin{array}{r}\text { Yes } \\
\text { No }\end{array}$ & $\begin{array}{l}1 \\
2\end{array}$ & $\begin{array}{l}\text { If No: } \\
708\end{array}$ \\
\hline 707 & $\begin{array}{l}\text { Who talked to you about HIV or AIDS? } \\
\text { Anyone else? } \\
\text { Multiple responses possible. Circle all } \\
\text { mentioned. }\end{array}$ & $\begin{array}{r}\text { Teacher } \\
\text { Family/household } \\
\text { member } \\
\text { Other: }\end{array}$ & $\begin{array}{c}1 \\
2 \\
66\end{array}$ & \\
\hline 708 & $\begin{array}{l}\text { Can people reduce their chances of getting } \\
\text { the AIDS virus by having just one uninfected } \\
\text { sex partner who has no other sex partners? }\end{array}$ & $\begin{array}{r}\text { Yes } \\
\text { No } \\
\text { Don't know/Not sure }\end{array}$ & $\begin{array}{c}1 \\
2 \\
88\end{array}$ & \\
\hline 709 & $\begin{array}{l}\text { Can people reduce their chance of getting the } \\
\text { AIDS virus by using a condom every time they } \\
\text { have sex? }\end{array}$ & $\begin{array}{r}\text { Yes } \\
\text { No } \\
\text { Don't know/Not sure }\end{array}$ & $\begin{array}{l}1 \\
2 \\
88\end{array}$ & \\
\hline 710 & $\begin{array}{l}\text { Is it possible for a healthy-looking person to } \\
\text { have the AIDS virus? }\end{array}$ & $\begin{array}{r}\text { Yes } \\
\text { No } \\
\text { Don't know/Not sure }\end{array}$ & $\begin{array}{c}1 \\
2 \\
88\end{array}$ & \\
\hline 711 & $\begin{array}{l}\text { Can people get the AIDS virus from mosquito } \\
\text { bites? }\end{array}$ & $\begin{array}{r}\text { Yes } \\
\text { No } \\
\text { Don't know/Not sure }\end{array}$ & $\begin{array}{c}1 \\
2 \\
88\end{array}$ & \\
\hline 712 & $\begin{array}{l}\text { Can people get the AIDS virus by sharing food } \\
\text { with someone who has AIDS? }\end{array}$ & $\begin{array}{r}\text { Yes } \\
\text { No } \\
\text { Don't know/Not sure }\end{array}$ & $\begin{array}{c}1 \\
2 \\
88\end{array}$ & \\
\hline
\end{tabular}




\begin{tabular}{|c|c|c|c|c|c|c|c|}
\hline \multirow{5}{*}{$\begin{array}{l}\text { No. } \\
713\end{array}$} & \multirow{5}{*}{$\begin{array}{l}\text { Question } \\
\text { Can the virus that causes AIDS be } \\
\text { transmitted from a mother to her baby: }\end{array}$} & \multicolumn{5}{|c|}{ Coding Categories } & \multirow[t]{5}{*}{ SKIP } \\
\hline & & \multirow{4}{*}{\multicolumn{2}{|c|}{$\begin{array}{l}\text { d) During pregnancy? } \\
\text { e) During delivery? } \\
\text { f) By breastfeeding? }\end{array}$}} & Yes & No & DK & \\
\hline & & & & 1 & 2 & 8 & \\
\hline & & & & 1 & 2 & 8 & \\
\hline & & & & 1 & 2 & 8 & \\
\hline 714 & $\begin{array}{l}\text { In your opinion, if a female teacher has the } \\
\text { AIDS virus but is not sick, should she be } \\
\text { allowed to continue teaching in the school? }\end{array}$ & & $\begin{array}{r}\text { Yes } \\
\text { No } \\
\text { Don't know/Not sure }\end{array}$ & \multicolumn{3}{|c|}{$\begin{array}{c}1 \\
2 \\
88\end{array}$} & \\
\hline 715 & $\begin{array}{l}\text { In your opinion, if a pupil has HIV but is not } \\
\text { sick, should he or she be allowed to continue } \\
\text { attending school? }\end{array}$ & & $\begin{array}{r}\text { Yes } \\
\text { No } \\
\text { Don't know/Not sure }\end{array}$ & \multicolumn{3}{|c|}{$\begin{array}{c}1 \\
2 \\
88\end{array}$} & \\
\hline 716 & $\begin{array}{l}\text { In your opinion, are pupils from families with } \\
\text { HIV-infected individuals treated unkindly by } \\
\text { other students? }\end{array}$ & & $\begin{array}{r}\text { Yes } \\
\text { No } \\
\text { Don't know/Not sure }\end{array}$ & \multicolumn{3}{|c|}{$\begin{array}{c}1 \\
2 \\
88\end{array}$} & \\
\hline 717 & $\begin{array}{l}\text { In your opinion, are pupils from families with } \\
\text { HIV-infected individuals treated unkindly by } \\
\text { teachers? }\end{array}$ & & $\begin{array}{r}\text { Yes } \\
\text { No } \\
\text { Don't know/Not sure }\end{array}$ & \multicolumn{3}{|c|}{$\begin{array}{c}1 \\
2 \\
88\end{array}$} & \\
\hline 718 & $\begin{array}{l}\text { I have a few more questions about HIV. If you } \\
\text { don't want to answer, that is all right. } \\
\text { Have you ever been tested to see if you have } \\
\text { the AIDS virus? }\end{array}$ & & $\begin{array}{r}\text { Yes } \\
\text { No } \\
\text { Don't know }\end{array}$ & \multicolumn{3}{|c|}{$\begin{array}{l}1 \\
2\end{array}$} & $\begin{array}{l}\text { If No: } \\
721 \\
\text { If DK: } \\
721\end{array}$ \\
\hline 719 & Did you get the results of your test? & & $\begin{array}{r}\text { Yes } \\
\text { No }\end{array}$ & \multicolumn{3}{|c|}{$\begin{array}{l}1 \\
2\end{array}$} & \\
\hline 720 & $\begin{array}{l}\text { Would you tell me the result of your test? We } \\
\text { will keep the result completely confidential. }\end{array}$ & & $\begin{array}{r}\text { Positive } \\
\text { Negative } \\
\text { Indeterminate } \\
\text { No answer }\end{array}$ & \multicolumn{3}{|c|}{$\begin{array}{l}1 \\
2 \\
3 \\
4\end{array}$} & \\
\hline 721 & $\begin{array}{l}\text { Do you know of a place where people can go } \\
\text { to get tested for the AIDS virus? }\end{array}$ & & $\begin{array}{r}\text { Yes } \\
\text { No }\end{array}$ & \multicolumn{3}{|c|}{$\begin{array}{l}1 \\
2\end{array}$} & \\
\hline \multicolumn{8}{|c|}{$\begin{array}{l}\text { Sexual behavior: My next few questions relate to sex. These questions may be awkward to answer. If you do } \\
\text { not wish to answer, you do not have to. Please just say PASS. If you do choose to answer, please be as honest } \\
\text { as you can. The information you provide will help us to improve our programs to meet the needs of children } \\
\text { like you. Everything that you tell me will be held strictly confidential. }\end{array}$} \\
\hline No. & Questions & \multicolumn{4}{|c|}{ Coding Categories } & \multicolumn{2}{|c|}{ SKIP } \\
\hline 722 & $\begin{array}{l}\text { Have you ever had sexual intercourse? } \\
\text { For the purposes of this survey, "sexual } \\
\text { intercourse" is when a male puts his penis } \\
\text { inside of a female's vagina or inside of } \\
\text { someone's anus. }\end{array}$ & & $\begin{array}{l}\text { Yes } \\
\text { No }\end{array}$ & $\frac{1}{2}$ & & If No & 801 \\
\hline 723 & $\begin{array}{l}\text { How old were you when you first had sex? } \\
\text { If respondent cannot recall, ask them to } \\
\text { estimate. }\end{array}$ & & Age (years) & {$[-1$} & & & \\
\hline 724 & Have you had sex in the past 1 year? & & $\begin{array}{r}\text { Yes } \\
\text { No }\end{array}$ & $\frac{1}{2}$ & $\frac{1}{2}$ & If No & 801 \\
\hline 725 & $\begin{array}{l}\text { How many different sex partners have you } \\
\text { had in the past } 1 \text { year? }\end{array}$ & & lumber of sex partners & {$[-1$} & —] & & \\
\hline 726 & $\begin{array}{l}\text { Thinking about the last time you had sex, did } \\
\text { you or your partner use a condom? }\end{array}$ & & $\begin{array}{r}\text { Yes } \\
\text { No } \\
\text { Don't know }\end{array}$ & $\begin{array}{l}1 \\
2 \\
8\end{array}$ & & & \\
\hline
\end{tabular}




\section{SECTION 8: ACCESS TO HIV PREVENTION, CARE, AND SUPPORT}

We have arrived at the last section of the questionnaire. We are almost finished. Thank you very much for your participation so far.

Instructions: Respondents should respond only for services that they personally have received. The caregiver or head of household will also be asked. Data may be cross-checked. OR, this question may be posed to either the adult or the child (instead of both).

\begin{tabular}{|c|c|c|c|c|}
\hline No. & Question & Coding categories & & \\
\hline \multirow{10}{*}{801} & \multirow{3}{*}{$\begin{array}{l}\text { I am going to read out a list } \\
\text { of items and services. Please } \\
\text { tell me if YOU have received or } \\
\text { accessed any of these items of } \\
\text { services in the last } 6 \text { months. }\end{array}$} & $\begin{array}{l}\text { g) Health care from a health } \\
\text { professional }\end{array}$ & Yes & No \\
\hline & & $\begin{array}{l}\text { h) Home visit from a community worker } \\
\text { or social worker }\end{array}$ & Yes & No \\
\hline & & $\begin{array}{l}\text { i) Free school supplies or a school } \\
\text { uniform }\end{array}$ & Yes & No \\
\hline & \multirow{3}{*}{$\begin{array}{l}\text { Read out services. Confirm } \\
\text { responses with caregiver. Circle } \\
\text { final responses. }\end{array}$} & Mosquito net & Yes & No \\
\hline & & \multicolumn{3}{|l|}{ Ages 13-17 } \\
\hline & & $\begin{array}{l}\text { k) Information on how to prevent HIV } \\
\text { and other sexually transmitted } \\
\text { infections }\end{array}$ & Yes & No \\
\hline & \multirow{4}{*}{$\begin{array}{l}\text { [WILL MODIFY THIS SECTION } \\
\text { AFTER CONSULTING WITH } \\
\text { ZAMFAM AND CONFIRMING } \\
\text { TYPES OF SERVICES] }\end{array}$} & l) Information on birth spacing & Yes & No \\
\hline & & m) Livelihood training & Yes & No \\
\hline & & \multicolumn{3}{|l|}{ Ages 15-17 } \\
\hline & & n) Life skills training & Yes & No \\
\hline
\end{tabular}

\section{-END OF SECTION-}

\section{SECTION 9: MUAC}

We are almost finished! May I [measure] your arm?

\begin{tabular}{|c|l|l|l|}
\hline No. & \multicolumn{1}{|c|}{ Question } & \multicolumn{1}{c|}{ Coding Category } \\
\hline 901* & $\begin{array}{l}\text { Measure child's arm } \\
\text { circumference. Document } \\
\text { measurement. }\end{array}$ & MUAC & [_l__].[_l__ $\mathrm{Cm}$ \\
\hline
\end{tabular}

I have come to the end of my questions. Is there anything you would like to add or ask us?

Thank you for participating in this interview!

\section{3}

END TIME

$[-|+|:[-1]$




\section{APPENDIX 14 INTERVENTION SUMMARY REPORTS BY ZAMFAM PARTNERS}

\subsection{Lusaka and Copperbelt Provinces: Expanded Church Response}

Expanded Church Response (ECR) is a faith-based National NGO established in 2003 to help the church, an institution in virtually every community in Zambia, to have an expanded, comprehensive, and coordinated response to HIV/AIDS and associated development issues throughout the country. ECR's efforts have helped awaken and transform the faith-based response to best practice initiatives in villages and urban compounds to reverse stigma and discrimination, expand initiatives to mitigate the impact of HIV/AIDS, and build solutions sustainable by the community.

Using eight approaches i.e. Household centred, needs-based, age appropriate interventions, integrated, youth driven, evidence based, cost-effective and coordinated. ECR in partnership with Catholic Relief Services (CRS), Zambia Open Community Schools (ZOCs) and Serenity Harm Reduction Programme Zambia (SHARPZ) is implementing the Zambia Family (ZAMFAM) project which is a five-year USAID/PEPFAR-funded Project, aimed at supporting the GRZ, through the Ministry of Community Development, Mother and Child Health ( $\mathrm{MCDMCH})$, Ministry of Gender and Child Development, USAID-funded partner organizations or implementing partners working in Zambia to implement various activities related to vulnerable children and families/ caregivers programming. This project is being implemented under ECR as the prime partner in two provinces i.e. Lusaka and Copperbelt. In Lusaka, it is being implemented in eight (8) districts namely: Lusaka, Chongwe, Rufunsa, Luangwa, Shibuyunji, Chilanga, Kafue, and Chirundu. On the Copperbelt, it is being implemented in ten (10) districts namely: Masaiti, Chililabombwe, Ndola, Chingola, Kitwe, Luanshya, Kalulushi. Lufwanyama, Mufurila and Mpongwe. 


\section{Major Interventions:}

- Family-tailored: through community volunteers and para-social workers (PSW)

- Community Level Services: encouraged throughout the program

- Needs-based: addressing specifically low selfefficacy, poverty, psychosocial well-being of the caregiver, and parenting knowledge

- Age-appropriate: Target each level of the household with specific programming

- Integrated approach: expands opportunity and provides access to community level services such as community savings groups (CSGs)

- Youth Driven Approach: through Adolescent and Youth clubs to engage, support, and connect

- Quality-Focused Approach: through BruceJain Quality of Care's six elements to strengthen Community Based Organizations (CBOs)

- Evidence-based and Cost-effective: Builds capacity of implementation and programs

- Coordinated Approach: leverages CBOs and public structures to strengthen community level initiatives

- Targets 21,000 households and 100,0000 OVC below age of 18

\section{Benefits for:}

- OVC: Birth registration, Educational support, Reference to ART and adherence support, Health, Nutrition, Social protection

- Youth: Life skills training, Alcohol prevention and treatment training, Increase Vocational certification, opportunities, transport, fees, etc)

- Family: Training in parenting skills, Trainings in Community Saving groups, Pediatric HIV education

- Caregivers: Trainings in Community Saving Groups, Trainings and certifications in lay counseling, Training in national database M\&E tools, Trainings in health, hygiene, MUAC, Incentives(e.g. gumboots, raincoats, T-shirts, umbrellas)

- FBOs: In view of USAID Forward Initiative: develop and provide internal mentoring system, Training in relevant OCB modules, Training in P3 engagement, Training in OVC minimum standards, Training in quality framework approaches, May be provided with small sub grant for specific activities, May benefit from future ECR partnerships 


\section{ZAMFAM SOUTH AND CENTRAL}

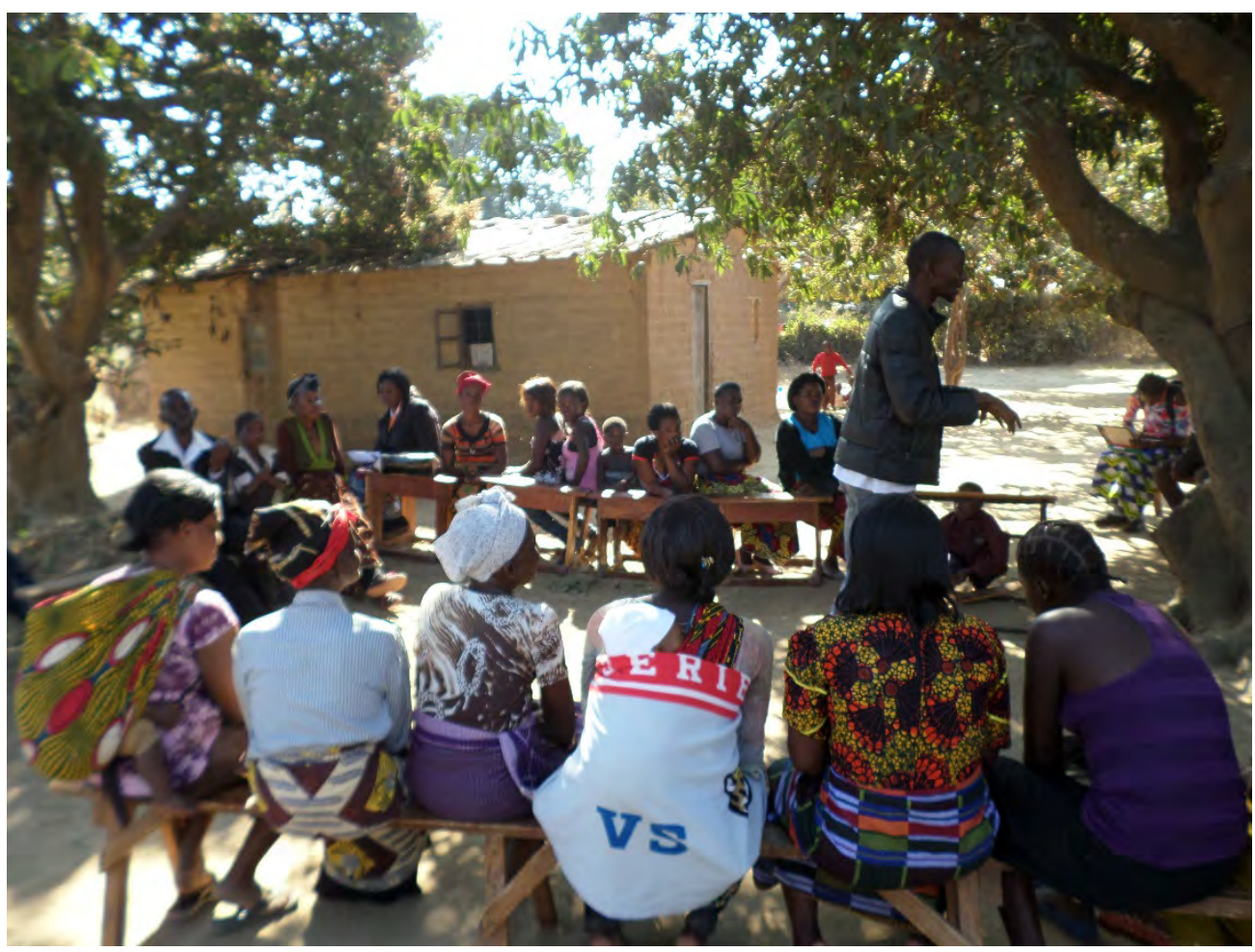

Intervention Packages

$20^{\text {th }}$ November 2015 to $30^{\text {th }}$ September 2016

To:

Population Council in Zambia 


\section{TABLE OF CONTENTS}

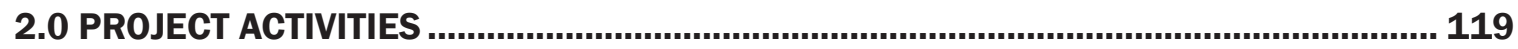

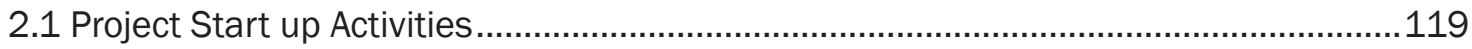

2.2 Transitioning STEPS OVC Children into ZAMFAM South Central....................................120

2.3. Enrollment of new children in ZAMFAM South Central ...................................121

3.0 ACHIEVEMENTS BY KEY RESULT AREAS .............................................................. 122

Result 1-Resilience of households to care for children and adolescents living with, affected by and/or vulnerable to HIV measurably increased.

Result 2-Child wellbeing status measurably improved due to provision and accessing of quality care and support services.

Result 3-Capacity of government and community structures to care for and support children and adolescents living with, affected by and/or vulnerable to HIV measurably increased.

Result 4-Strengthened shared learning and evidence base to improve programming and inform policy and program investment.

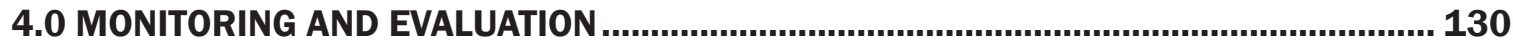

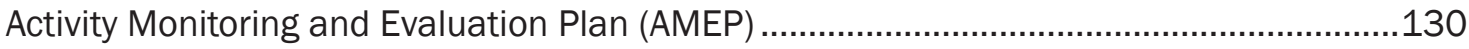

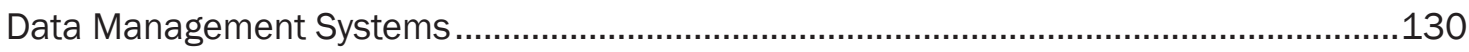

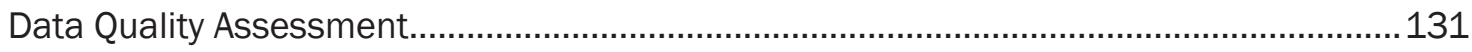

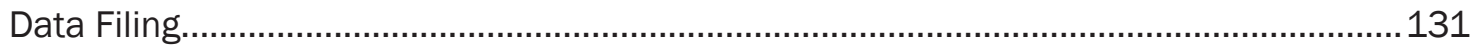

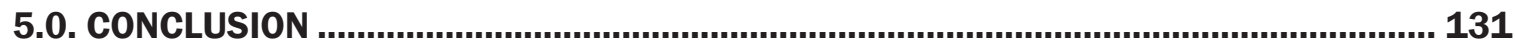




\section{LIST OF ACRONYMS}

\begin{tabular}{|c|c|}
\hline AIDS & Acquired Immune Deficiency System \\
\hline AG & Action Group \\
\hline AMEP & Activity Monitoring and Evaluation Plan \\
\hline CHEP & Copperbelt Health Education Project \\
\hline $\mathrm{CHW}$ & Community Health Worker \\
\hline Creative & Creative Associates International \\
\hline $\mathrm{COP}$ & Chief of Party \\
\hline CWAC & Community Welfare Assistant Committee \\
\hline DAPP & Development Aid from People to People \\
\hline DCOP & Deputy Chief of Party \\
\hline DMS & Data Management System \\
\hline DWAC & District Welfare Assistance Committee \\
\hline ECR & Expanded Church Response \\
\hline HIV & Human Immune Virus \\
\hline HPP & The Federation Humana People to People \\
\hline IEC & Information, Education and Communication material \\
\hline JCM & Jesus Care Ministries \\
\hline KAFHI & Kabwe Adventist Family Health Institute \\
\hline MCDSW & Ministry of Community Development and Social Welfare \\
\hline$M \& E$ & Monitoring and Evaluation \\
\hline $\mathrm{NZP}+$ & Network of Zambian People Living with HIV \\
\hline OVC & Orphans and Vulnerable Children \\
\hline PLWHA & People Living With HIV and AIDS \\
\hline STEPS OVC & $\begin{array}{l}\text { Sustainability Through Economic Strengthening, Prevention } \\
\text { and Support for Orphans Vulnerable Children }\end{array}$ \\
\hline TSA & The Salvation Army \\
\hline USAID & United States Agency for International Development \\
\hline VAG & Village Action Groups \\
\hline ZAMFAM & Zambia Family Activity \\
\hline
\end{tabular}




\section{BASIC PROJECT INFORMATION}

\author{
Project Number \\ Project Name \\ Sector \\ Finance Arrangements \\ Implementing Agency \\ Sub Awardees
}

Implementing Partners

Project Goal

Expected Results

Start Date

End Date
AID-611-A-16-00002
USAID - DAPP ZAMFAM South Central Project

HIV and AIDS

Donor Support United States Agency for International

Development (USAID)

Development Aid from People to People (DAPP)

Creative Associates International, Inc

Network of Zambian People Living with HIV and AIDS (NZP+)

Kabwe Adventist Family Health Institute (KAFHI)

Ministry of Health (MoH), Ministry of Community Development and Social Welfare (MCDSW), communities and schools

To improve the care and resilience of vulnerable populations in the Central and Southern Provinces of Zambia, specifically targeting OVC and PLWHA by supporting, protecting, and strengthening the capacity of children, families, and communities.

Resilience of households to care for children and adolescents living with, affected by and/or vulnerable to HIV measurably increased.

Child wellbeing status measurably improved due to provision and accessing of quality care and support services.

Capacity of government and community structures to care for and support children and adolescents living with, affected by and/or vulnerable to HIV measurably increased.

Shared learning and evidence base to improve programming and inform policy and program investment strengthened.

20 November 2015

19 November 2020 
Table 1: ZAMFAM South Central project districts

\begin{tabular}{|c|c|c|c|}
\hline \multicolumn{4}{|c|}{ Southern Province } \\
\hline & District & \# of Project Areas & Project Life Span \\
\hline 1 & Chibombo & 7 & 5 years \\
\hline 2 & Kabwe & 9 & 5 years \\
\hline 3 & Kapiri Mponshi & 6 & 5 years \\
\hline 4 & Mumbwa & 6 & 5 years \\
\hline 5 & Choma & 5 & $11 / 2$ years (Possible extn) \\
\hline 6 & Gwembe & 1 & $11 / 2$ years \\
\hline 7 & Kalomo & 5 & $1 \frac{1 / 2}{2}$ ears \\
\hline 8 & Kazungula & 2 & $1 \frac{1 / 2}{\text { years }}$ \\
\hline 9 & Livingstone & 8 & 5 years \\
\hline 10 & Mazabuka & 8 & 5 years \\
\hline 11 & Monze & 2 & $11 / 2$ years (Possible extn) \\
\hline 12 & Sinazongwe & 3 & 5 years \\
\hline & Total & 62 & \\
\hline
\end{tabular}




\subsection{EXECUTIVE SUMMARY}

ZAMFAM South Central project is operating in Southern and Central provinces covering 15 districts, seven in Central province and eight in Southern province. The project is providing services to OVCs by supporting, protecting, and strengthening the capacity of children, families, and communities and is strengthening the resilience of families to support orphans and vulnerable children and improving their economic status through livelihood strengthening activities.

The project started with the transitioning of the approximately 100,000 OVC from the recently completed STEPS OVC Project. 87,000 of the children below the age of 17 and having been active within the past 6 months were access and either enrolled in ZAMFAM or graduated. Three former Lead Agencies under the STEPS OVC Project were sub-granted to take part in the transitioning process.

Operation areas for ZAMFAM South Central are partly the former areas covered under the STEPS OVC project. New areas had been identified in areas with a high population density and high HIV prevalence level.

During this reporting period, ZAMFAM South Central in the targeted districts, spread over 62 project areas, each manned with 1 project leader and 3 community mobilizers. Each staff organizes and supervises activities for 2,000 OVC.

Essential community structures to spearhead the planned interventions were established. This include engagement of community leaders, health facilities and school staff through community gatherings and dialogue meetings, identification and training of 5760 Child Care Volunteers (CCVs), training of 413 Community Health Workers (CHWs) in accelerated HIV child care and treatment, establishing and training the leadership of 1,703 Village/ Community Action Groups and identification and or strengthening of 476 Saving Groups.

In close cooperation with local leaders the project identified, assessed and enrolled a total of 129,913 OVCs which represent 103\% achievement.

During the registration process it was established that 72,245 children and their guardian do not know the HIV status of the children.

Services to the enrolled OVC started through provision of training and organization of activities utilizing the mentioned structures. Lessons were carried out in the Village Action Groups involving discussion related to the major needs of OVC as well as lessons and actions among the group members to improve the household surroundings, thereby promoting healthy living environment for the children.

The trained CCVs and CHWs got connected to the Village Action Groups and the targeted families and started to provide services including referring children for HIV testing and supporting the children tested HIV positive to ensure recommended treatment and care. A total of 9,723 children were referred to HIV testing in the reporting period. 
The project started to work with the Community Welfare Assistance Committees (CWACs) as well as with District Welfare Assistance Committees (DWACs) to support vulnerable populations including OVC.

The data base was developed to record the result of the Child Status Index (CSI), as well as capture the services provided to the children based on the project Activity Monitoring and Evaluation Plan (AMEP).

Activities were carried out by DAPP in cooperation with its partners namely Creative Associates, $\mathrm{KAFHI}$ and NZP+. The project further identified 10 community based organizations which were in the process of being sub-granted to supplement efforts under ZAMFAM SC. 


\subsection{PROJECT ACTIVITIES}

\subsection{Project Start up Activities}

\subsubsection{Project Launch}

ZAMFAM was jointly launched by DAPP and Expanded Church Response (ECR) with support from USAID on the 20th of January 2016. The launch was a significant event that brought visibility to the project and its goals, as it brought key stakeholders in the same room, including children who participated with songs, poems, sketches and speeches.

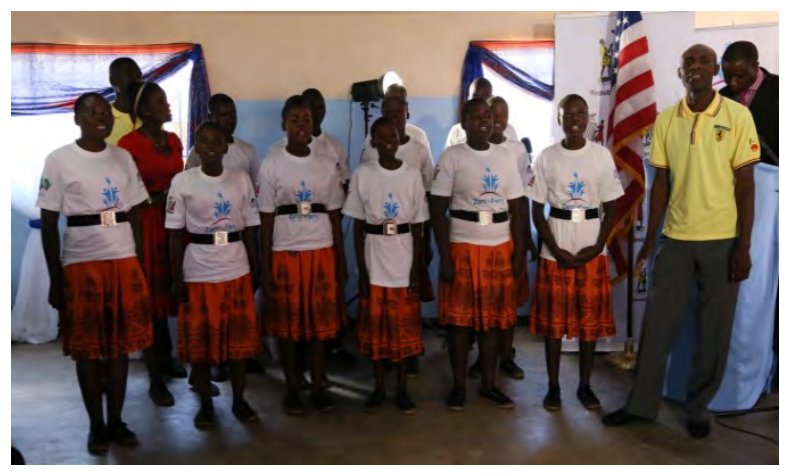

Picture 1: Children singing during the launch

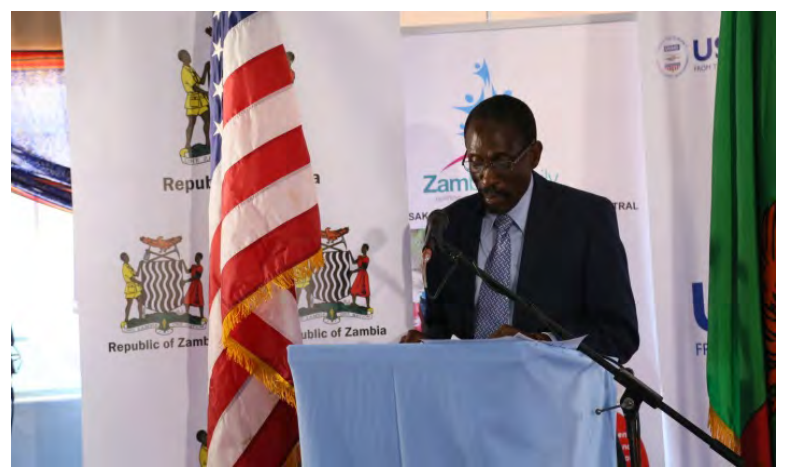

Picture 2: The guest of honour delivering a key note

\subsubsection{Staff Recruitment and Training}

ZAMFAM South Central successfully recruited all project key staff including one Chief of Party (COP); two Deputy Chiefs of Party (DCOP); one Finance and Operations Director; one Monitoring and Evaluation Specialist; two Assistant Monitoring and Evaluation Specialists; one Community Mobilization Specialist; eight District Coordinators; 62 Project Leaders; 186 Community Mobilisers; 16 Data clerks; five Accounts Clerks; 4 Drivers and 10 Office Assistants.

Following their recruitment, the COP and the DCOPs were oriented in USAID and DAPP regulations and procedures in order for them to understand the donors requirements, rules and regulations, as well as the project's implementing organization's policies and standard operating procedures. The rest of the staff were also successfully trained in areas relevant to their roles, 61 Project Leaders (17 female and 44 male) were trained for a period of 4 weeks from 11th January to 13th February 2016 at the DAPP national headquarters, and 186 Community Mobilisers were trained for 2 weeks from 29th May to 10th June 2016 in Kapiri, Chibombo and Mumbwa, Monze and Choma districts. 


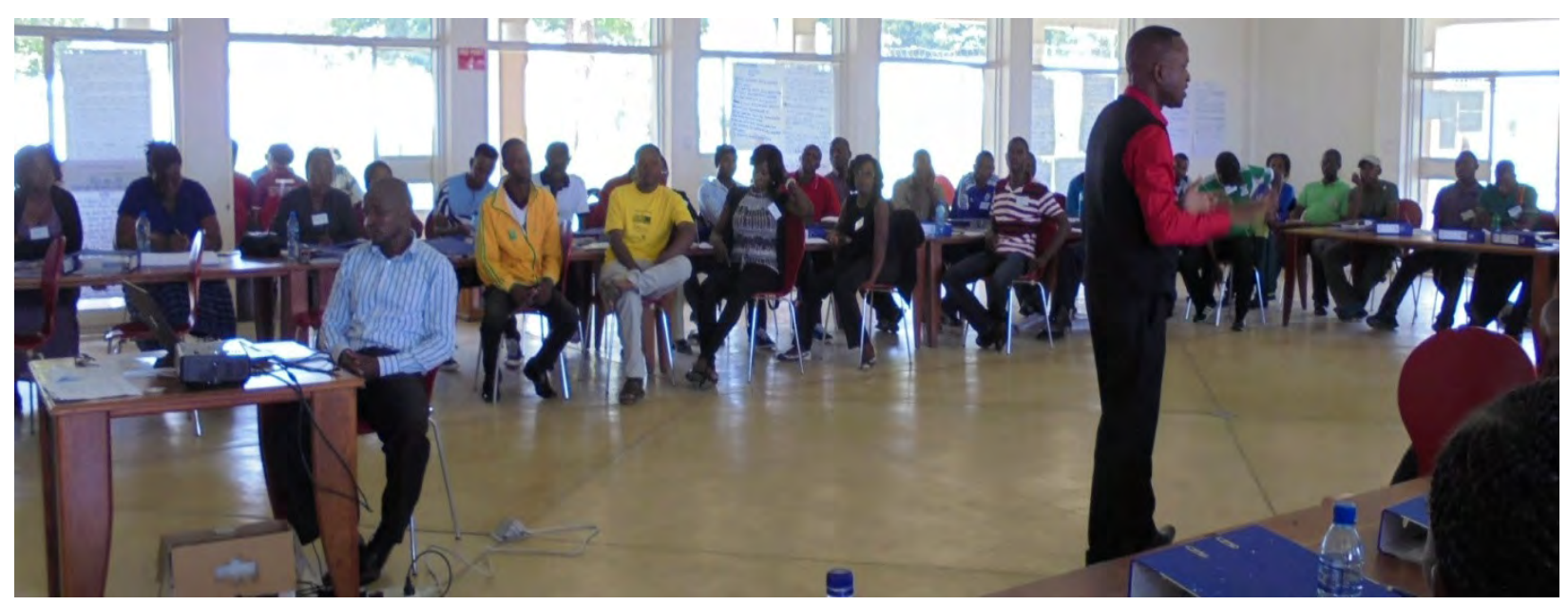

Project Leaders training: participants following the proceedings

\subsubsection{Establishment of District Project Offices}

Table 3: Distribution of offices and their usage

\begin{tabular}{|l|l|l|}
\hline District & Type of office & Location \\
\hline Kabwe & Regional/Provincial/District Offices & 27 Lukanga Road, Kabwe. \\
\hline Chibombo & District office & $\begin{array}{l}\text { Chibombo district next to the Chibombo } \\
\text { District Commissioner's house }\end{array}$ \\
\hline Kapiri Mposhi & District office & Tazara Township \\
\hline Mumbwa & District office & Mumbwa town \\
\hline Mazabuka & Provincial office & Kaonga \\
\hline Livingstone & District office & Airport Road \\
\hline Choma & District office & River Side \\
\hline Sinazongwe & District office & New Township \\
\hline Monze & Provincial office & Tagore \\
\hline
\end{tabular}

\subsubsection{Introductory Meetings at National, Provincial and District Levels}

As part of the project start up, ZAMFAM South Central staff including the COP, DCOP and the Community Mobilization Specialist held introductory meetings and briefings with provincial and district social welfare office, health and education offices. The meetings were convened with the purpose of introducing the ZAMFAM South Central project to GRZ and its officials at provincial and district levels in order to enhance collaboration with existing GRZ structures and ensure "buy in" and support from the relevant authorities.

\subsection{Transitioning STEPS OVC Children into ZAMFAM South Central}

ZAMFAM South Central with approval from USAID engaged three Sub-grantees namely The Salvation Army (TSA), Jesus Cares Ministry (JCM) and Copperbelt Health Education Project (CHEP). The role of these sub-grantees was to provide transitioning support for eligible beneficiaries of the STEPS OVC project to the ZAMFAM South Central project. 
Following assessments using the CSI tool, the children that qualified for enrolment as they scored 1 or 2 on the CSI assessment, were transitioned into ZAMFAM South Central, and those that did not qualify were graduated (if scoring 3 and 4 in all elements).

\subsection{Enrollment of new children in ZAMFAM South Central}

In addition to the children transitioned from STEPS OVC, ZAMFAM South Central identified and enrolled new children in the project from the scale up districts (close to 90,000 children). The project ensured that all relevant local stakeholders were included in the identification process of children including the local leaders, CWACs, school teachers and Community Health Workers (CHWs) from health facilities.

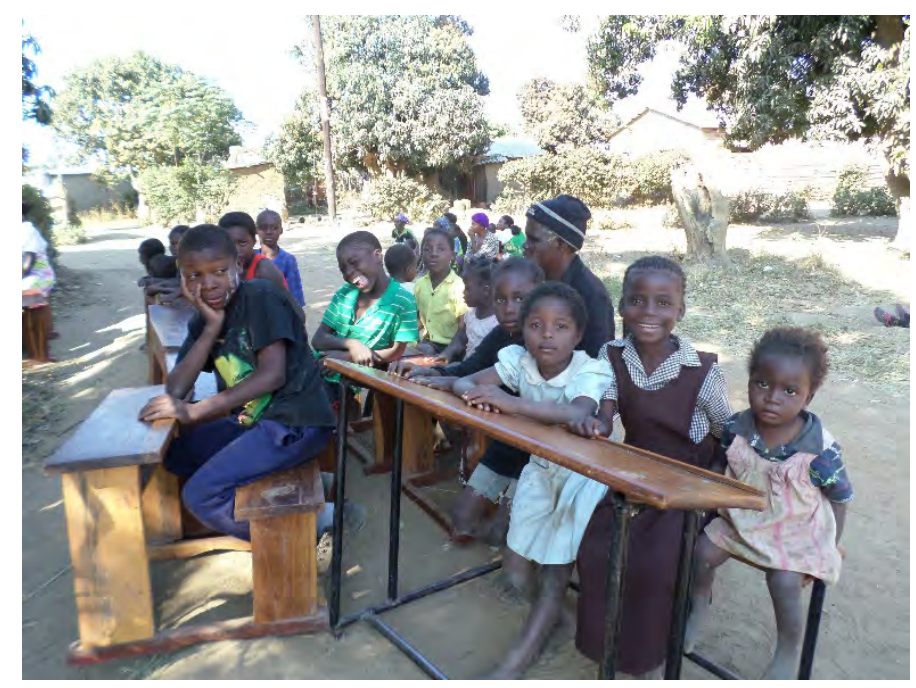

Table 4 Total number of children enrolled by district

\begin{tabular}{|lr|}
\hline District & Children enrolled \\
Chibombo & 10,439 \\
Kabwe & 22,408 \\
Kapiri-Mposhi & 12,651 \\
Mumbwa & 12,817 \\
Choma & 8,706 \\
Gwembe & 2,254 \\
Kalomo & 8,223 \\
Kazungula & 5,313 \\
Livingstone & 19,061 \\
Mazabuka & 20,711 \\
Monze & 5,077 \\
Sinazongwe & 2,254 \\
Total & $\mathbf{1 2 9 , 9 1 1}$ \\
\hline
\end{tabular}

The committees targeted households that had children who were/suspected to be HIV positive, orphans, children being looked by the elderly or ill guardians and those that were known to be living in a hostile environment. An identification form was used as a tool for identifying OVCs. All the OVCs who were identified were assessed using CSI forms and registered using a registration form by Project Leaders, Community Mobilisers and Child Care Volunteers (CCVs).

The CSI tool assess each child in the areas of food security, nutrition and growth, shelter, care, abuse and protection, wellness, health care services, emotional health, social behavior and education.

The registration form captures the children's demographic information and their HIV status.

129, 913 children $(64,674$ female and 65,238 male) consisting newly identified and children transiting from STEPS OVC were enrolled.

The registration process revealed that 3626 children were known to be HIV positive, while 53,541 were HIV negative and 72,745 had unknown HIV status. 


\subsection{ACHIEVEMENTS BY KEY RESULT AREAS}

3.1. Result 1-Resilience of households to care for children and adolescents living with, affected by and/or vulnerable to HIV measurably increased.

\subsubsection{Establish Action Groups, train Action Group (AG) leaders in use of the CSI tool for} $A G$, club activities related to resilience of households to care for OVC and improved child wellbeing, and startup of activities in the $A G$

In its effort to empower families taking care of OVCs, ZAMFAM South Central commenced the establishment of Village Actions Groups (VAGs) in rural and Community Action Groups (CAGs) in urban/ sub urban communities in the project areas in scale up districts in Southern and Central provinces. The aim of the VAG is to provide a fora for the village to come together to build resilience in the vulnerable populations. During the period under review a total of 1,793 Village Action Groups and 853 Action Groups were established which both represent $85 \%$ achievement while 746 Saving Groups were enrolled (some of them were formed under STEPS OVC and others were formed by the project)

Comprehensive manuals have been developed for each of the mentioned groups consisting of content material related to the specific aim of the group as well as a defined program with detailed instruction to the facilitators (coordinators in the groups) as well as to the club members and with ideas for actions and activities in the clubs as well as within the targeted families.

Services provided to individual registered OVC are captured through reporting forms submitted by the Village Action Groups. By the end of the reporting period the project had captured health services provided to 18,798 registered OVC.

VAG Meeting in Liteta village in Chibombo District

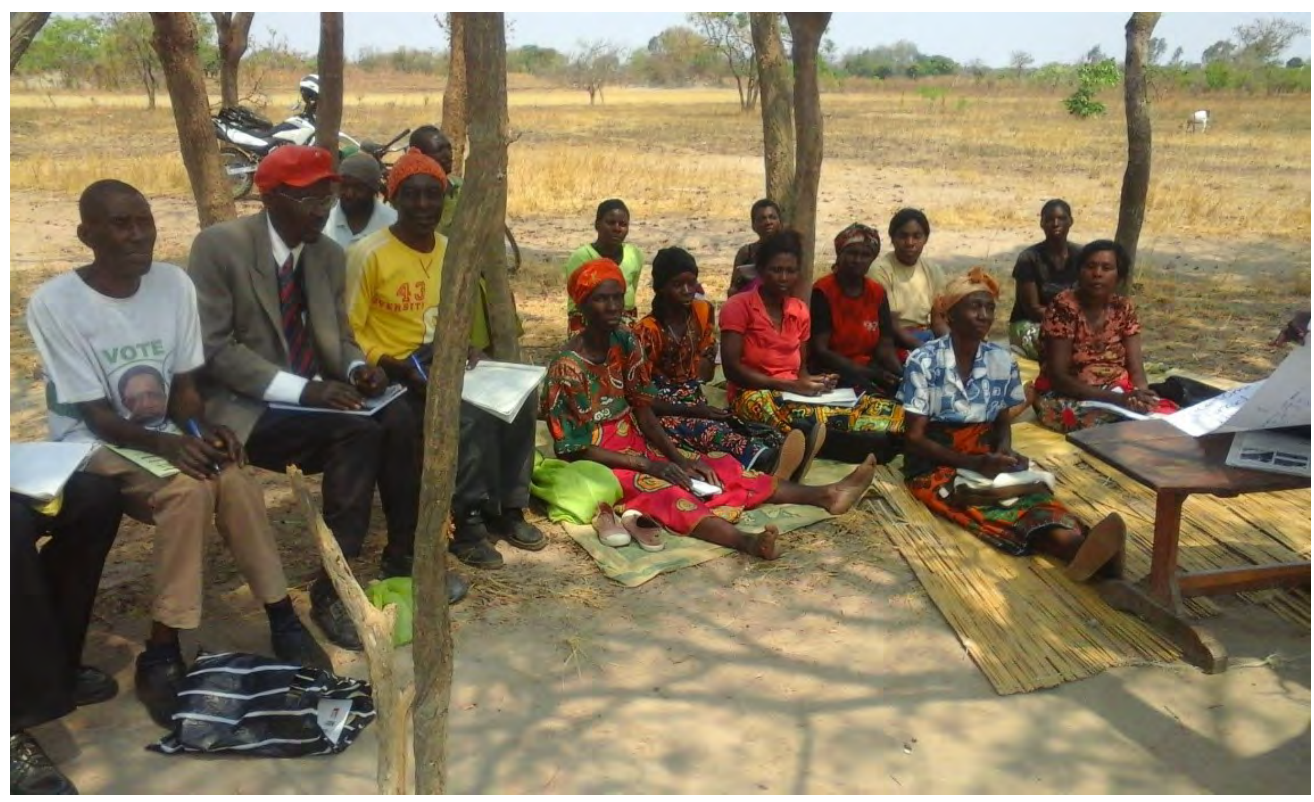



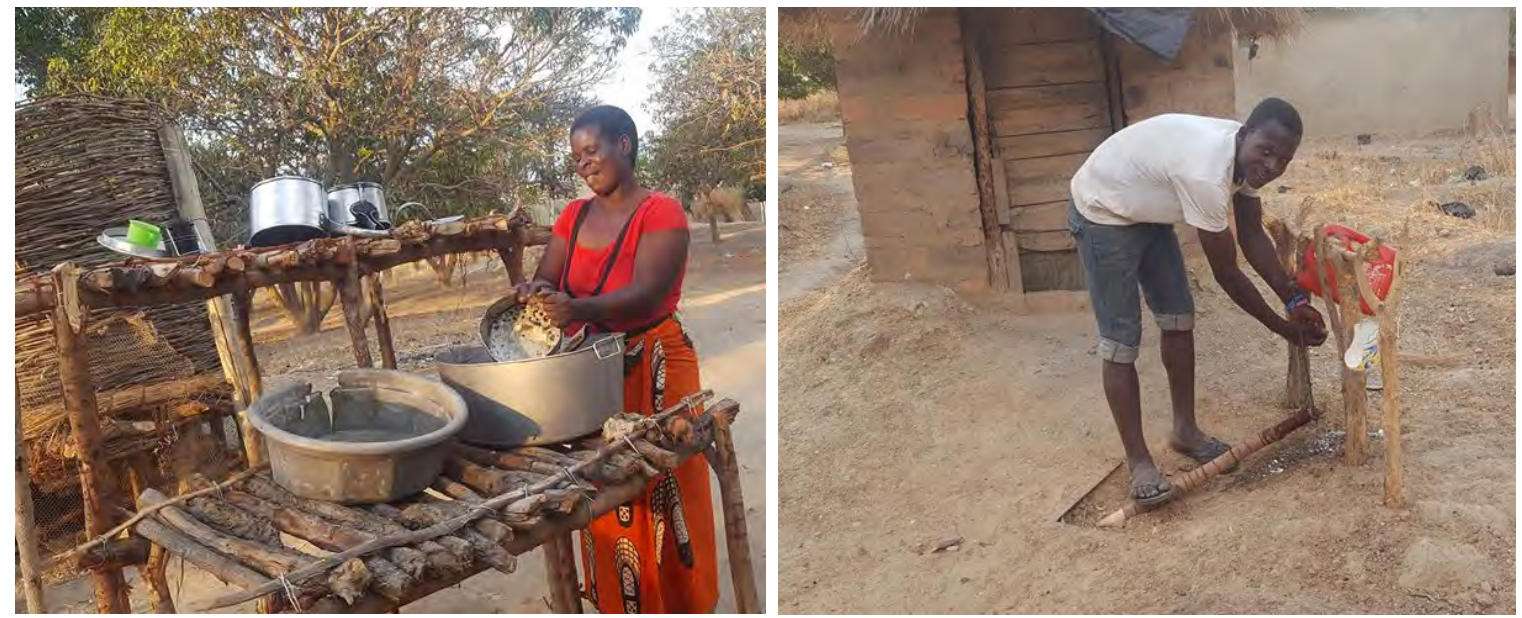

Improved hygiene facilities to improve basic health care

\subsubsection{Establish Youth Clubs and Kids Clubs and start activities in the clubs}

Manuals for the two type of clubs were developed and printed. The clubs will start in early 2017.

\subsubsection{Establish Support Groups for PLWHA, train trainers and start activities in the groups} ZAMFAM South Central conducted a mapping exercise to identify existing support groups in all the project areas during the start-up of the project. The objective was to identify existing support groups and link them to NZP+; identify areas that have no support groups and identifying support groups that were no longer active.

In collaboration with NZP+, the project identified and strengthened 97 support groups that were being supported by training of peer educators. 33 peer educators have been trained in Livingstone by NZP+ during the reporting period and are being supported with managing and establishing support groups.

\subsubsection{Mobilization and training of Child Care Volunteers in CSI assessment and in making case management plans for OVC}

During the reporting period, ZAMFAM South Central project identified and recruited 5,760 Child Care Volunteers (CCVs) to assist in the identification, assessment, enrolment and ultimate provision of information and support services to OVCs. The CCVs were recruited to work with Project Leaders and Community Mobilisers in the recruitment and follow up of OVCs.

\section{Each CCV is assigned to be} working with about 20 children and is responsible for the follow up of OVCs and monitoring of

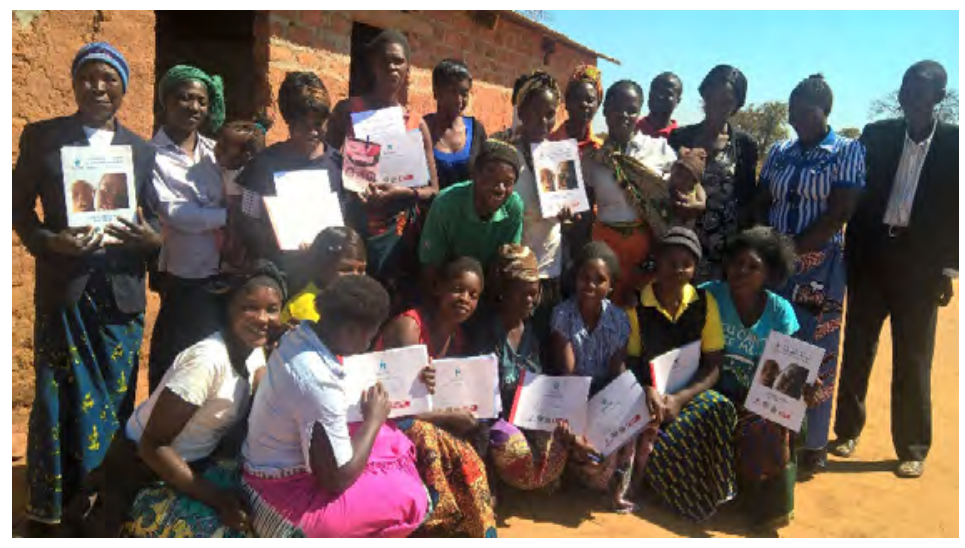


progress of each child and their households. They are members of the project structures such as VAGs and AGs.

\subsubsection{Conduct community /dialogue meetings}

During the period reporting period, ZAMFAM conducted 924 community/ dialogue meetings in the various project areas. The aim of the meetings was to establish collaboration with the community stakeholders, review registration and recruitment of children, understand other interventions that currently being implemented the communities. These meetings were also used to disseminate and share project information with the communities regarding the establishment of VAGs in scale up districts and AGs in sustained districts.

\subsubsection{Distribute 'pass on gift' of small livestock and legumes to most vulnerable households}

Through the VAGs, the project distributed "Pass on Gifts" in terms of seed namely Cow Peas, Pigeon Peas, Sweet Potatoes and improved Cassava to the most vulnerable. Each family planted 1 lima of crops

\subsubsection{Establishment of Savings and Internal Lending Committees (SILC)} The ZAMFAM South Central project has

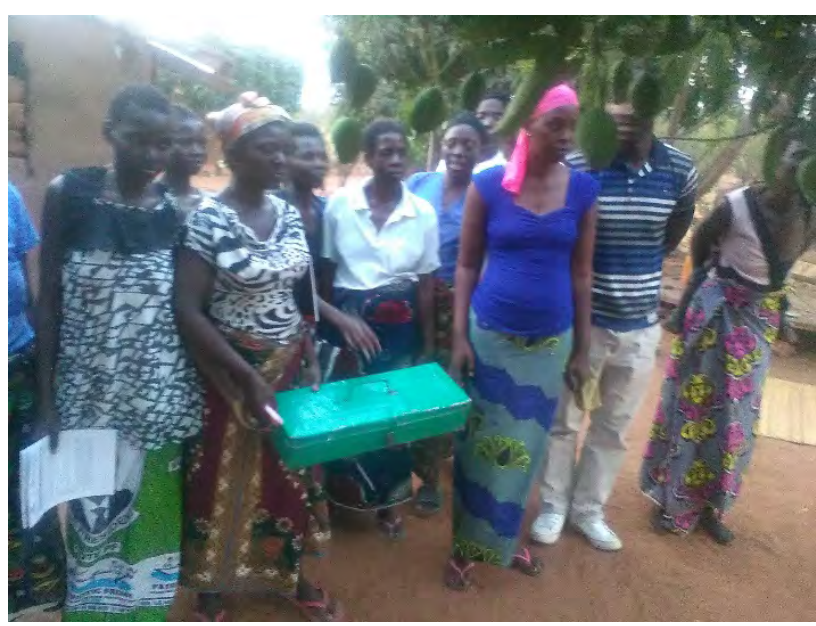
incorporated the SILC concept in the saving groups that are formed either as a sub AG for a VAG in scale up districts, or as a standalone AGs in sustained districts. The SILC groups are formed for the purpose of encouraging families to generate and save money to strengthen their economic status and wellbeing. During the period under review, the project identified and facilitated the formation of 476 SILC groups in the target areas.

These groups consist of parents, guardians and other members of the households where the OVCs are drawn from.

Table 6: ZAMFAM project summary of achievements of result area 1.

\begin{tabular}{|l|l|c|c|c|}
\hline No & Description of activity & $\begin{array}{c}\text { Output goals } \\
\text { Year1 }\end{array}$ & $\begin{array}{c}\text { Output goals } \\
\text { achieved to } \\
\text { date }\end{array}$ & $\begin{array}{c}\text { Percentage of } \\
\text { achievement }\end{array}$ \\
\hline 1 & Establish Village Action Groups & 2,000 & 1,703 & $85 \%$ \\
\hline 2 & $\begin{array}{l}\text { Established Action Groups (Pass on Gift } \\
\text { groups, Garden and Nutrition Groups }\end{array}$ & 1,000 & 852 & $85 \%$ \\
\hline 3 & $\begin{array}{l}\text { Mobilization of Child Care Volunteers } \\
\text { (CCVs) }\end{array}$ & 6,000 & 5,760 & $96 \%$ \\
\hline 4 & Conduct community dialogue meetings & 800 & 924 & $116 \%$ \\
\hline 5 & Establish Kids/Youth Clubs & 320 & 0 & 0 \\
\hline 6 & Establish/Strengthen Support Groups & 124 & 97 & $78 \%$ \\
\hline 7 & $\begin{array}{l}\text { Establish and strengthen Saving and } \\
\text { Internal Lending Communities (SILC) }\end{array}$ & 124 & 476 & $384 \%$ \\
\hline
\end{tabular}




\subsection{Result 2-Child wellbeing status measurably improved due to provision and accessing of quality care and support services.}

\subsubsection{OVC assessed using the Child Status Index tool}

ZAMFAM South Central trained CCVs in how to use the CSI's system. The CSI summary guide and CSI recording forms used under STEPS OVC were revised to ease the data capturing and to improve alignment of the content to the local conditions in the target communities. An estimated 150,000 children were assessed including the 129,913 children enrolled as well as the children in STEPS OVC that graduated as a result of the assessment. Additionally, the children transitioning from STEPS that later graduated were assessed and were graduated based on the results of the assessment. The information from the CSI forms were being entered into the project database.

\subsubsection{Conduct BCC campaigns and actions to decrease HIV infection and promote Counseling and Testing among OVC and adults connected to the OVC and at risk through testing} campaigns

During the reporting period, ZAMFAM South Central, in collaboration with health facility staff and Community Health Workers (CHWs) conducted 346 testing campaigns. The campaigns involved door-todoor mobilisation, counselling and testing as well as linking those who test positive to health facilities for treatment and support.

\subsubsection{Distribute block grants to schools}

A survey was carried out in 216 schools in the target areas, 137 government and 79 community schools. The project established the system for giving out the block grants. The first grants to be given in 2016 would include text books, benches, black boards as well as exercise books to targeted individual children. The purpose is to contribute towards increasing access to and improving the quality of education.

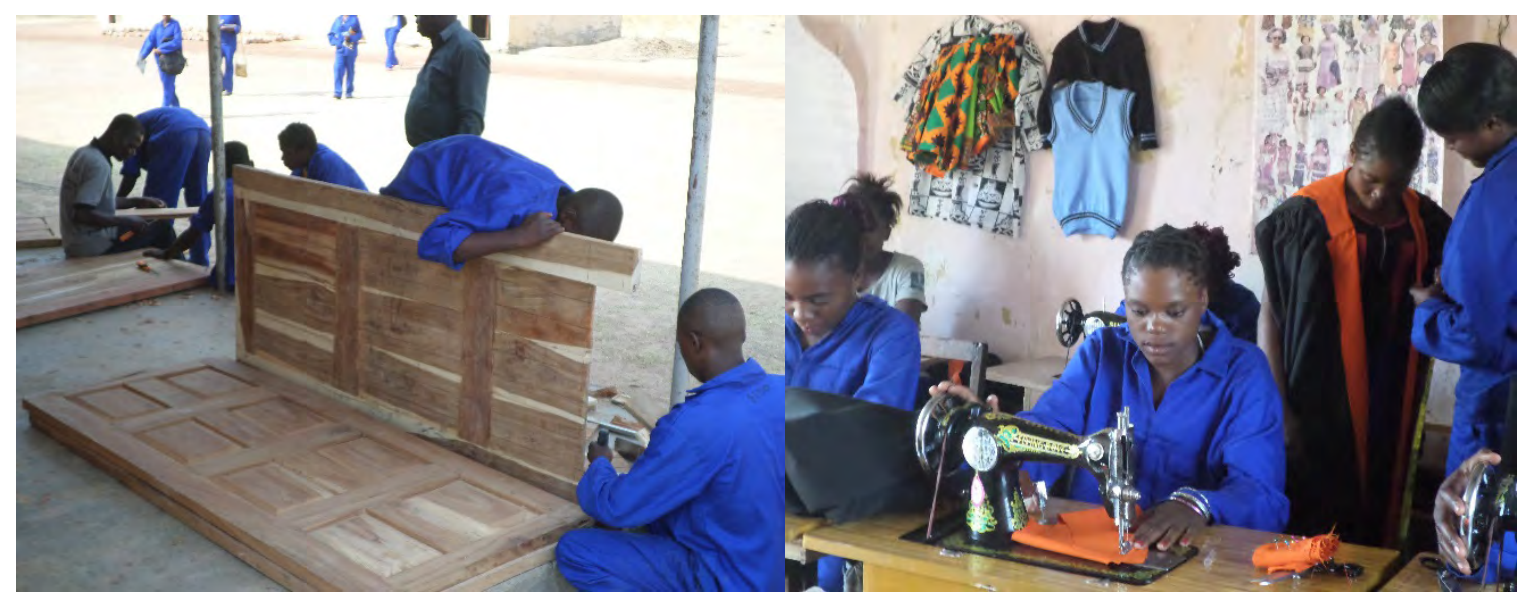

Adolescent OVC in Vocational Training in the Children's Town Vocational Training Centre in Chibombo 
To start up, the project provided a block grant to one vocational training school in Chibombo, with 30 OVC registered under ZAMFAM sc (14 girls and 16 boys).

\subsubsection{Conduct stakeholders' coordination meetings to strengthen referral and follow up systems for ART treatment, HIV prevention, sexual and reproductive health services and PMTCT services}

ZAMFAM participates in coordination meetings at national, provincial and district levels. At the district level, stakeholder meetings were held in all districts where ZAMFAM South Central has a presence. These meetings served as a platform for each stakeholder to introduce their activities, and discuss the formation of referral networks among the partners that are supporting different service areas.

\subsubsection{Train peer educators from the Kids Clubs and Youth Clubs with age-appropriate} information related to HIV prevention, sexual and reproductive health, gender-based violence The ZAMFAM South Central project through its partnership with NZP+ commenced the training and mobilization of Youth advocates in Kabwe and Livingstone districts. 34 youth advocates ( 8 males and 26 females) were trained in mobilization and the formation of Adolescent/ Youth support groups. These trainings were carried out as part of the "Saving a life at a time: enhancing access to and utilization of prevention, treatment, sexual reproductive health, psychosocial support by young people living with HIV/AIDS" initiative.

\subsubsection{Establish and strengthen support groups for young OVC living with HIV, train peer educators and advocates and start activities in groups}

In addition to the community mapping of support groups and the training of youths as peer educators, ZAMFAM through working closely with health facilities and CHWs has been supporting the testing and identification of young people living with HIV and AIDS. Using the list of support groups identified during the mapping exercise, ZAMFAM refers and encourages the young people to join support groups in their area. In addition to the 97 adult support groups identified during the mapping exercise, the project through the sub partner NZP+ established 7 adolescent and youth support groups. 
Table 8: ZAMFAM project summary of achievements of result area 2

\begin{tabular}{|c|l|c|c|c|}
\hline No & Description of activity & $\begin{array}{c}\text { Output goals } \\
\text { Year 1 }\end{array}$ & $\begin{array}{c}\text { Output goals } \\
\text { achieved to date }\end{array}$ & $\begin{array}{c}\text { Percentage of } \\
\text { achievement }\end{array}$ \\
\hline 1 & $\begin{array}{l}\text { Enrollment of children in ZAMFAM South } \\
\text { Central }\end{array}$ & 125,000 & 129,913 & $104 \%$ \\
\hline 2 & $\begin{array}{l}\text { Number of testing drives/Mobile testing } \\
\text { campaigns }\end{array}$ & 400 & 346 & $89 \%$ \\
\hline 3 & Rehabilitation of most at-risk OVC & 20 & 0 & $0 \%$ \\
\hline 4 & $\begin{array}{l}\text { Conduct stakeholder coordination } \\
\text { meetings to strengthen referral and follow } \\
\text { up systems }\end{array}$ & 20 & 16 & $80 \%$ \\
\hline 4 & $\begin{array}{l}\text { Conduct district stakeholder work } \\
\text { sessions }\end{array}$ & 20 & 22 & $110 \%$ \\
\hline 5 & $\begin{array}{l}\text { Train peer educators from the Kids clubs } \\
\text { and youth clubs with age appropriate } \\
\text { information related to HIV prevention, } \\
\text { sexual and reproductive health, GBV. }\end{array}$ & 640 peer \\
\hline 6 & $\begin{array}{l}\text { Organizational and technical capacity } \\
\text { building of sub grantees }\end{array}$ & 20 & 34 & $5 \%$ \\
\hline 7 & $\begin{array}{l}\text { Support and align with other USAID } \\
\text { partners in system strengthening }\end{array}$ & 3 & 4 & $133 \%$ \\
\hline 8 & $\begin{array}{l}\text { Establish and strengthen support groups } \\
\text { for young OVC living with HIV, train peer } \\
\text { educators and advocates and start } \\
\text { activities in groups }\end{array}$ & 40 & 7 (on going) & $18 \%$ \\
\hline
\end{tabular}

\subsection{Result 3-Capacity of government and community structures to care for and support children and adolescents living with, affected by and/or vulnerable to HIV measurably increased.}

\section{3,3.1. Conduct district stakeholders work sessions}

Work sessions were conducted with transition partners CHEP, TSA and Jesus care ministries. These took place at district, provincial and national levels. The aim of the work sessions was to ensure a smooth transition process for the children from STEPS OVC to ZAMFAM. As a result of these work sessions, the ZAMFAM project staff at district level found it easy to operate at community level having been introduced to the relevant offices and existing community structures.

\subsubsection{Organizational and technical capacity building of sub-grantees}

\section{Engagement of local sub grantees:}

ZAMFAM South Central signed two sub grantee contracts with Kabwe Adventist Health Institute (KAFHI) and Network of People living with HIV and AIDS (NZP+) which would run from 1st July 2016 to 30th September 2020. 


\section{Capacity building of identified sub grantees}

Through its partnership with Creative Associates, ZAMFAM built capacity to the two local sub grantees, KAFHI and NZP+ in Livingstone, Mazabuka, Mumbwa, Chibombo and Kabwe. ZAMFAM conducted organisation capacity assessments using the Creative Institutional Capacity Assessment (ICA) tool which was self-administered by KAFHI and NZP+. Using the results of the ICA tool, ZAMFAM worked with the sub grantees to develop Institutional Strengthening Plans targeting the specific identified needs of each of the organisations.

To meet these capacity needs, ZAMFAM provided one-on-one technical support through coaching and mentoring in Monitoring and Evaluation which had the biggest capacity gaps. The team held a Monitoring and Evaluation Training of Trainers where DAPP, KAFHI and

NZP+ secretariat staffs were in attendance from September 12-16, 2016.

\subsubsection{Strengthen community structures (DWACs, ACCs, CWACs, Social Welfare Offices, Traditional Leaders,)}

ZAMFAM South Central through its partnership with Creative conducted training of trainers (TOT) for the District Welfare Assistant Committees (DWAC) from July 25-28, 2016. The participants came from Kapiri Mposhi, Mumbwa, and Chibombo districts of Central Province. The trainings were facilitated by three Provincial Social Welfare staff who are Public Welfare Assistance Scheme master trainers. The master trainers were supported by ZAMFAM staff. 27 people were trained who included two Provincial Senior Social Welfare Officers, one Social Welfare officer, Ministry of Local Government District Council representatives, youth group representatives, Zambia Police (Victim Support Unit), Ministry of Chief and Traditional Affairs and Zambia Association for People living with Disability (ZAPD) representatives. Other participants came from $\mathrm{MOH}, \mathrm{MCDSW}$, Ministry of Home Affairs and Community Based Organizations (CBOs).

\subsubsection{Community Health Workers and other service providers trained and supported to support OVC and PLWHA to access health services}

During the reporting period, ZAMFAM South Central trained 413 CHWs in Community Comprehensive Childhood and Adolescent HIV Care. The CHWs are the link between the health facilities and the communities and provide a range of care and services for children and adolescents. These include HIV counseling and testing services,

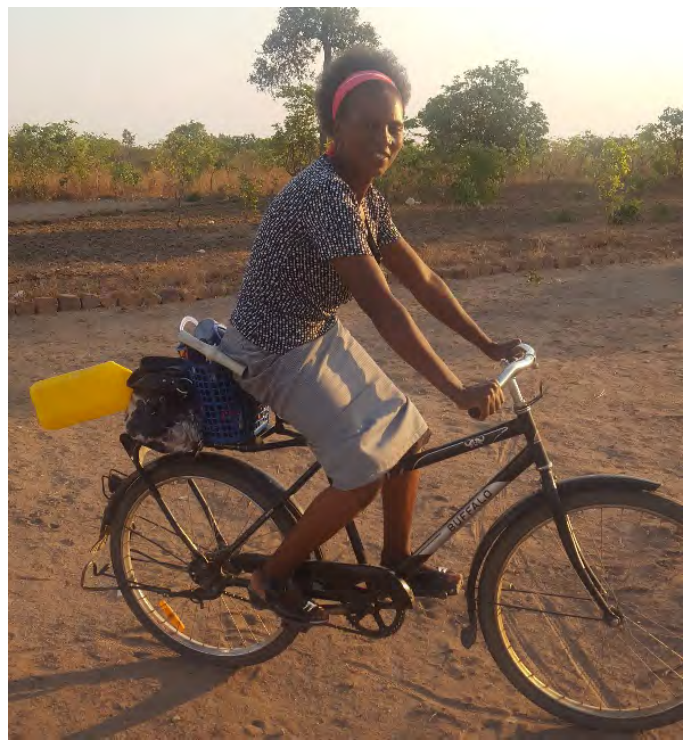

Trained $\mathrm{CHW}$ in Chibombo equipped with a bicycle for easy transport to visit OVC clients referral of HIV positive individuals from the community to health facilities to access treatment, and adherence support to those already on ART. The CHWs work closely with the Project Leaders, CCVs and Community Mobilisers and are linked to VAGs as key contacts for health related activities. 

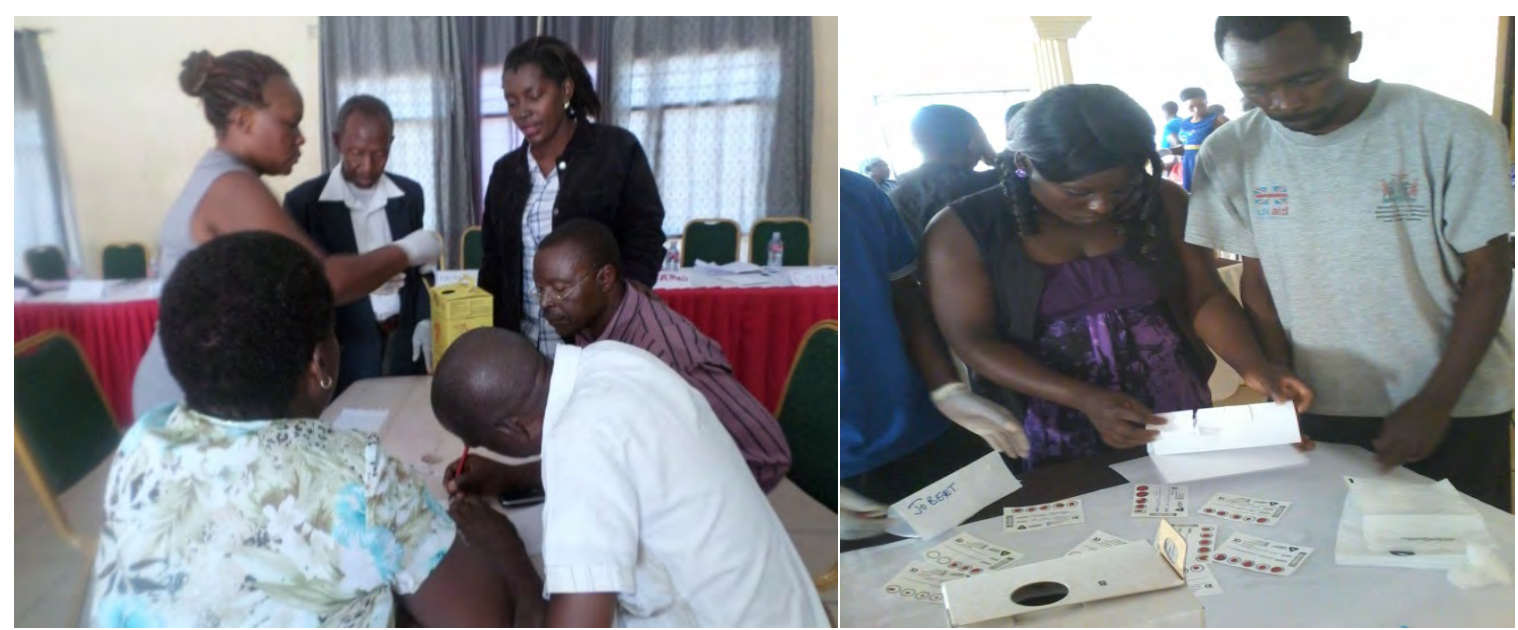

CHWs being trained in ACT

\subsubsection{Training of CWACs and others in OVC care, support and protection, child wellbeing assessment (CSI tool) and making household's case plans}

ZAMFAM South Central identified and was working with CWACs and ACCs in each project areas in the implementation of its activities. During the reporting period, ZAMFAM had completed the development, mobilisation and organisation of training tools and materials for the CWACs and ACC training in collaboration with the Community Rising Project. These materials included reporting templates and the Public Welfare Assistance Training Manual. A total of 360 copies had been printed in preparation for the trainings.

Table 9: ZAMFAM project summary of achievements of result area 3

\begin{tabular}{|c|l|c|c|c|}
\hline No & Description of activity & $\begin{array}{c}\text { Output } \\
\text { goals Year1 }\end{array}$ & $\begin{array}{c}\text { Output goals } \\
\text { achieved to date }\end{array}$ & $\begin{array}{c}\text { \% of } \\
\text { achievement }\end{array}$ \\
\hline 1 & $\begin{array}{l}\text { Conduct stakeholder coordination } \\
\text { meetings to strengthen referral and follow } \\
\text { up systems }\end{array}$ & 20 & 19 & $95 \%$ \\
\hline 02 & $\begin{array}{l}\text { Conduct district stakeholder work } \\
\text { sessions }\end{array}$ & 20 & 22 & $110 \%$ \\
\hline 03 & $\begin{array}{l}\text { Strengthen community structures DWACs, } \\
\text { CWACs ACCs Social Welfare (No of } \\
\text { meetings) }\end{array}$ & $\begin{array}{c}500 \\
\text { meetings }\end{array}$ & 48 & $10 \%$ \\
\hline 04 & $\begin{array}{l}\text { Organizational and technical capacity } \\
\text { building of sub grantees }\end{array}$ & 20 CBOs & 2 & $10 \%$ \\
\hline 05 & $\begin{array}{l}\text { Support and align with other USAID } \\
\text { partners in system strengthening }\end{array}$ & $\begin{array}{l}3 \text { USAID } \\
\text { Projects }\end{array}$ & 3 & $100 \%$ \\
\hline 06 & $\begin{array}{l}\text { Training of Community Health } \\
\text { Workers (CHW) }\end{array}$ & 600 & 413 & $69 \%$ \\
\hline
\end{tabular}




\subsection{Result 4-Strengthened shared learning and evidence base to improve programming and inform policy and program investment.}

\subsubsection{Training CBOs and districts offices in the use of the National OVC Database}

The ZAMFAM project data base was developed in order to give comprehensive data about the state of the children enrolled as well as activities carried out. The implementation of the database and use of the data collected through this system would allow for close monitoring of beneficiaries, and provide a strong evidence base for the understanding of what approaches are working effectively and which ones require changes. The project successes and lessons learnt would be fully documented and disseminated to stakeholders.

\subsubsection{Conduct study in best practices and disseminate results}

ZAMFAM South Central was systematically collecting qualitative and quantitative data on its project activities. These data were being used to monitor implementation as well as to document best practices. In addition to the routine data management and documentation, ZAMFAM through its M\&E unit and field staff was working with Population Council in carrying out the benchmarking survey which was underway in Central and Southern provinces; and, Cohort study in Central Province only. Lists of registered beneficiaries in ZAMFAM from sampled areas of the survey had been extracted from the database and field staff were working with the survey team in identifying beneficiaries and areas of operation. ZAMFAM is a member of the technical advisory Group for the study whose aim is to determine if participation of HIV-positive children in ZAMFAM activities will be associated with greater improvements in child and household wellbeing indicators, including retention in care and treatment adherence, among others.

\subsubsection{Make Gender Assessment and Integration Strategy}

Gender mainstreaming is an integral component of HIV/AIDS Programming under the ZAMFAM South Central project. The project developed a Gender Integration Strategic Plan (GISP) which had been approved by USAID. ZAMFAM.

\subsection{MONITORING AND EVALUATION}

\subsection{Activity Monitoring and Evaluation Plan (AMEP)}

ZAMFAM South Central developed the Activity Monitoring and Evaluation Plan (AMEP). The AMEP was submitted to USAID for approval and had since been approved. All monitoring and evaluation activities conducted in the reporting period were therefore guided by this document.

\subsection{Data Management Systems}

The project set up Data Management Systems (DMS) which are based on the approved Activity AMEP. Data collection tools had been finalized and distributed in the field and field staffs started using the tools to collect data. The project also supported sub grantees under the project with the development and rollout of DMS. Specifically, KAFHI was provided with and oriented in the use of the modified beneficiary database. 


\subsection{Data Quality Assessment}

During the reporting period, the project conducted its first Data Quality Assessment (DQA) in all ZAMFAM implementing districts using a Measure Evaluation "Data Verification and System Assessment Audit Form." The main purpose of the DQA was to assess the level of completeness, correctness and consistency of data and whether the data collection processes were being followed. The DQA process looked at data that is being collected from the field against what was being entered into the database system and what was being reported. This will be a continuous process and will be conducted quarterly.

\subsection{Data Filing}

The project has developed systems for data filling including a system of having individual folders for each family which would be hosted in each of the 6 project areas. This would be accessed by the project leaders and community mobilisers to obtain data from their specific 500 children (2,000 per project). 2 cabinets per project had been procured and the project staff was in the process of identifying sites to keep these cabinets safe such as with other NGOs, at health facilities and the like.

\subsection{CONCLUSION}

In conclusion ZAMFAM South Central was well established in 62 targeted communities with over 129,000 children enrolled. The project had been successful in meeting the majority of its deliverables outlined in the year one work plan, while a number of activities were ongoing. 
Project SOAR

Population Council 4301 Connecticut Ave, NW,

Suite 280

Washington, D.C. 20008 USA

Tel: +1 2022379400

Fax: +1 2022378410

Ideas. Evidence. Impact.

projsoar.org 